\title{
Subsyndromal depression hos äldre äldre personer
}

\author{
Mikael Ludvigsson
}

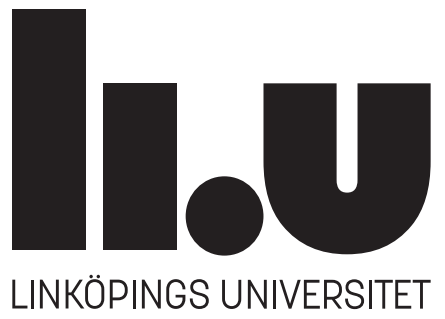

Institutionen för klinisk och experimentell medicin Avdelningen för neuro- och inflammationsvetenskap Linköpings universitet, 58183 Linköping Linköping 2018 
(C) Mikael Ludvigsson, 2018

Tryck: LiU-Tryck, Linköping, 2018

ISSN 0345-0082

ISBN 978-91-7685-229-3 
O Captain, my Captain! our fearful trip is done;

The ship has weather'd every rack, the prize we sought is won; The port is near, the bells I hear, the people all exulting, while follow eyes the steady keel, the vessel grim and daring:

But O heart! heart! heart! $O$ the bleeding drops of red, Where on the deck my Captain lies, Fallen cold and dead.

Walt Whitman (1819-1892). Leaves of Grass. 1900 



\section{Innehållsförteckning}

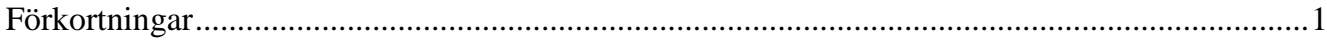

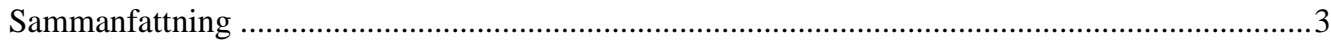

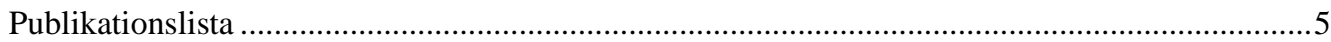

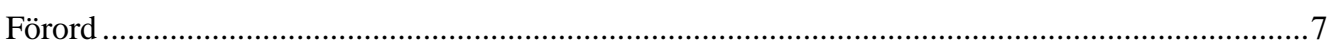

1. Introduktion: Depression, subsyndromal depression (SSD) och äldre äldre personer................9

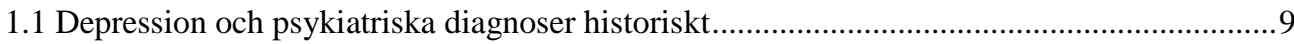

1.2 Subsyndromal depression (SSD): ursprung och definitioner ..........................................12

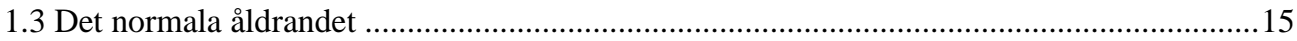

1.4 Förekomst och orsaker till depressivitet hos äldre äldre personer..................................... 17

1.5 Behandling av depressivitet hos äldre äldre personer .................................................. 18

1.6 Den komplexa zonen mellan normalt åldrande och syndromal depression ........................19

1.7 Det ovan identifierade kunskapsgapet, som motiv till doktorsavhandlingen ...................... 19

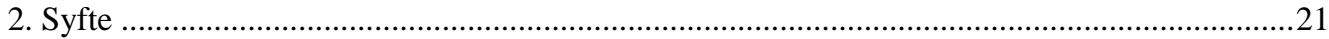

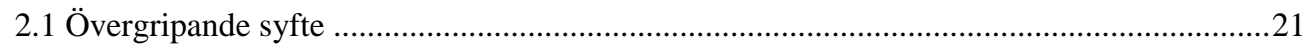

2.2 Specifika syften för respektive delstudie ...................................................................21

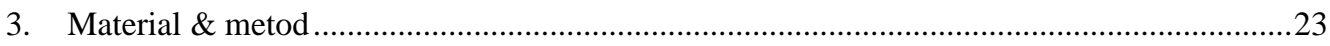

3.1 Populationsstudien ELSA85 och relationen till avhandlingsprojektet ................................23

3.2 Definitioner av SSD, syndromal depression, ND och normalt åldrande för

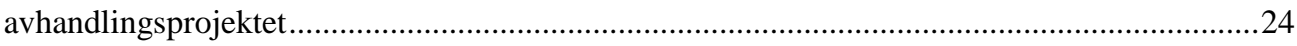

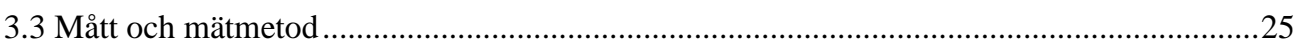

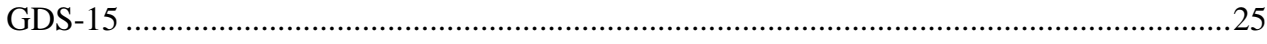

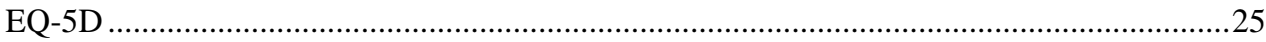

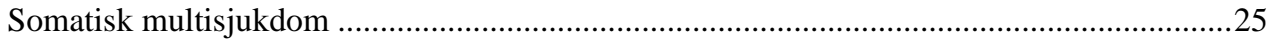

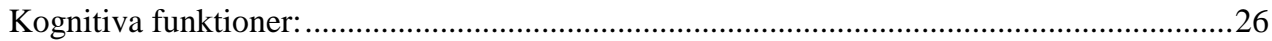

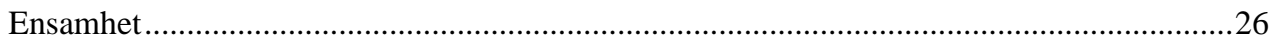

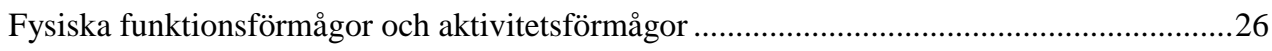

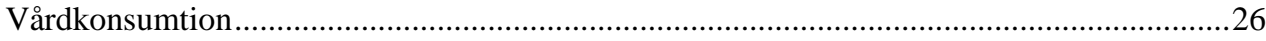

Direkta kostnader för sjukvård respektive kommunal omsorg ...........................................27

3.4 Design, urval och analytisk procedur i de olika studierna...............................................27

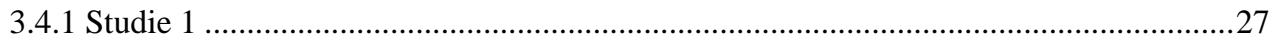




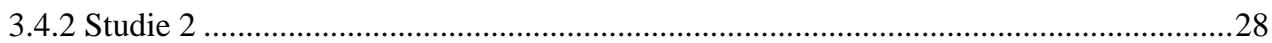

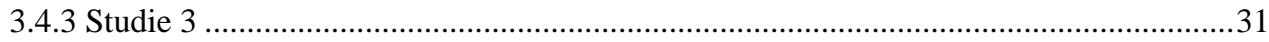

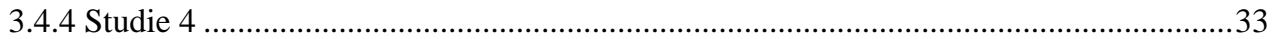

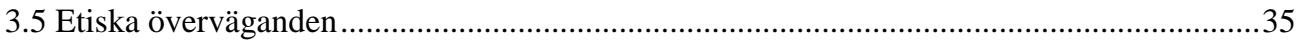

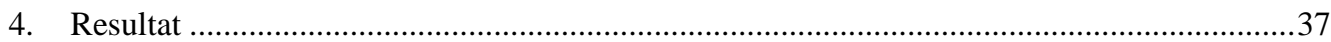

4.1 Studie 1: Normalt åldrande, SSD eller depression: en kvalitativ analys. ................................

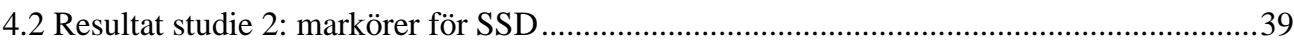

4.3 Resultat studie 3: direkta kostnader för personer med SSD ..............................................42

4.4 Resultat delstudie 4: morbiditet och mortalitet hos personer med SSD ............................47

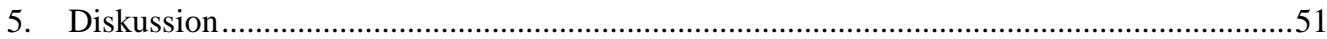

5.1 Tvärsnittsbilder av det komplexa området mellan normalt åldrande och depression ..........51

5.1.1 Upplevelser av tillvaron i ålderdomen, och heterogenitet inom depressivitet...............51

5.1.2 Bilder av depressivitet hos äldre äldre personer, typiska eller atypiska?......................53

5.2 Longitudinella aspekter av SSD bland äldre äldre personer..............................................55

5.2.1 Dynamiken och relevansen av SSD bland äldre äldre personer .................................55

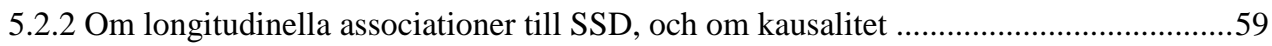

5.3 Betydelsen av SSD bland äldre äldre personer, och riskerna med medikalisering ..............61

5.3.1 Betydelsen av SSD hos äldre äldre personer för patienten, för sjukvården och för

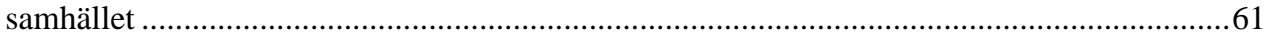

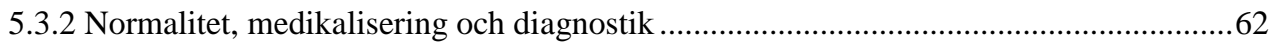

5.3.3 Prevention och behandling av SSD hos äldre äldre personer ......................................66

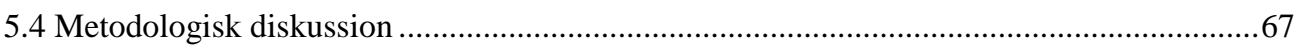

5.4.1 Validiteten för operationaliseringen av begreppet SSD i avhandlingen ......................67

5.4.2 Intern validitet för avhandlingsprojektet som helhet: ...............................................69

5.4.3 Extern validitet, generaliserbarhet eller transferabilitet: .........................................72

5.4.4 Reliabilitet för datainsamlingen i avhandlingsprojektet ..........................................72

5.4.5 Några kommentarer om kausalitet utifrån avhandlingsprojektet .................................73

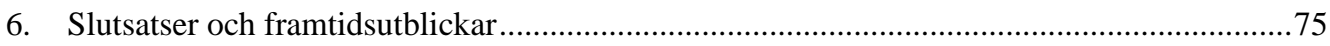

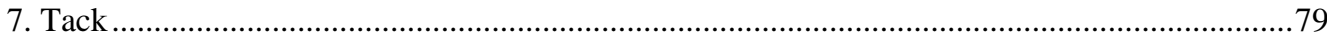

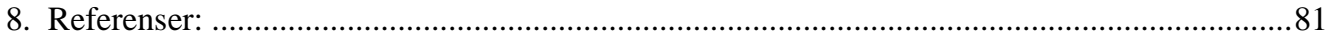

Appendix

Annex 1. The 15-item Geriatric Depression Scale (GDS-15) 


\section{Förkortningar}

ADL Activities of Daily Living, aktivitetsförmåga

CGA Comprehensive Geriatric Assessment

CI Konfidensintervall

COI Cost-of-Illness, Samhällskostnad för en sjukdom

Depr Ever Syndromal depression vid endera av två separata mätningar

DSM Diagnosregistret Diagnostic and Statistical Manual

ELSA85 Kohortstudien Elderly in Linköping Screening Assessment, 85 års ålder vid baslinjen

EQ-5D Skattningsskalan EuroQol - 5 Dimensioner

EQ-VAS EuroQol - Visuell Analog Skala

f.v.t. Före vår tideräkning, motsvarande före Kristus (f.Kr.) i den gregorianska kalendern i kristendomen

GDS-15 Skattningsskalan Geriatric Depression Scale, 15-frågeversionen

HR Hazard Ratio, Dödsintensitet

I-ADL Instrumentell ADL

IAM Instrumental Activity Measure

ICD International Classification of Diseases

KBT Kognitiv beteendeterapi

KPB Kostnad per brukare

KPP Kostnad per patient

LMM den statistiska metoden Linear Mixed Models

MMSE Det kognitiva testet Mini Mental State Examination

ND Icke-depression (non-depression)

ND Both ND vid båda av två separata mätningar

OR Oddskvot

P-ADL Personlig ADL

PaSMO Parallella Seriella Mentala Operationer

SD Standardavvikelse

SEK Svensk Ekonomisk Krona

SSD Subsyndromal depression

SSD Ever SSD vid endera av två separata mätningar

SSRI Selektiva serotoninåterupptagshämmare, antidepressivum

TMT-A Trail Making Test del A

v.t. Vår tideräkning, motsvarande efter Kristus (e.Kr.) i den gregorianska kalendern i kristendomen 


\section{Sammanfattning}

Bakgrund: Subsyndromal depression (SSD) eller subklinisk depression är ett vanligt affektivt tillstånd som kan beskrivas som depressivitet under gränsen för vad som kallas syndromal eller egentlig depressiv episod. Förekomsten av SSD har rapporterats vara ungefär $10 \% \mathrm{i}$ populationen, eller ungefär 2-3 gånger högre än förekomsten av syndromal depression. SSD jämfört med icke-depression (ND) är associerat med en lägre aktivitetsförmåga (ADL, Activities of Daily Living), lägre kognitiv funktion, lägre subjektiv hälsa, sämre psykiska utfall och en högre dödlighet.

Emellertid har flertalet studier om SSD hos äldre gjorts i åldersgruppen yngre äldre (60-80 års ålder), medan få studier har undersökt SSD hos äldre äldre personer (80+ års ålder). Eftersom många aspekter ( $\mathrm{t}$ ex multisjukdom, skörhet, funktionsförmågor och socialt beroende) generellt förändras mellan yngre äldre och äldre äldre åldrar, så finns det ett behov av ökad kunskap om SSD hos äldre äldre. Syftet med denna avhandling var att beskriva SSD, eller det komplexa området mellan syndromal depression och normalt åldrande, hos äldre äldre personer.

Metod: studie 1 baserades på kvalitativa intervjuer ( $n=27)$, medan studier 2-4 till stor del baserades på data från en prospektiv observationsstudie av en kohort, "Elderly in Linköping Screening Assessment" (ELSA85). ELSA85 hade en populationsbaserad design där man följde personer från 85 års ålder i tre uppföljande mätvågor. Depressivitet mättes med 15frågeversionen av Geriatric Depression Scale (GDS-15), som också användes för att definiera SSD i studierna.

Resultat: Analysen av de kvalitativa intervjuerna (studie 1) resulterade i fyra teman (livet går ned och kroppen sviktar, att klara sig själv, att hänga med, och att ta en dag i taget), vilka tillsammans gav en helhetsbild av SSD i de högsta åldrarna. I en jämförelse mellan SSD, ND och syndromal depression, så skiljde sig SSD kvalitativt från syndromal depression, men däremot inte tydligt från ND.

En tvärsnittsanalys av data från baslinjen av studien (studie 2) identifierade associerade faktorer till SSD bland äldre äldre personer, och enligt analysen med multipel logistisk respektive linjär regression så var det fyra domäner (sociodemografiska faktorer, sviktande fysisk funktion, neuropsykiatriska faktorer och existentiella faktorer) som var signifikant associerade med SSD.

I en fem års longitudinell uppföljning (studie 3) visades att direkta hälso- och sjukvårdskostnader per överlevnadsmånad och person var förhöjd hos personer med SSD jämfört med ND med ett storleksförhållande 1.45 (€634 vs €436), vilket var en signifikant skillnad även när man kontrollerade för somatisk multisjukdom.

I en åtta års longitudinell uppföljning visades att sjukligheten var förhöjd för personer med SSD jämfört med ND avseende personlig ADL (P-ADL), instrumentell ADL (I-ADL), ensamhet, subjektiv hälsa, och depressivitet. Däremot var inte kognitiv snabbhet, exekutiva funktioner eller global kognitiv funktion signifikant försämrade när man hade kontrollerat för relevanta variabler. 
Tvärtemot våra hypoteser var dödligheten under nio års tid inte förhöjd för personer med SSD jämfört med ND när man kontrollerade för relevanta kovariater.

Slutsatser: SSD hos äldre äldre personer ser olika ut hos olika personer, och personal i hälso- och sjukvården bör vara uppmärksamma på även andra depressiva tecken förutom de klassiska symtomen i diagnosregistren. SSD hos äldre äldre är associerat med förhöjda sjukvårdskostnader, förhöjd sjuklighet och lägre subjektiv hälsa. Med tanke på den höga förekomsten av SSD och den demografiska utvecklingen med ökande antal äldre äldre personer i samhället, så indikerar fynden behovet av att utveckla kliniska och samhälleliga strategier för att förebygga SSD och associerade negativa utfall. 


\section{Publikationslista}

1) Ludvigsson Mikael, Milberg Anna, Marcusson Jan, Wressle Ewa. Normal aging or depression? A qualitative study on the differences between subsyndromal depression and depression in very old people. Gerontologist. 2015 Oct;55(5):7609. doi: 10.1093/geront/gnt162. Epub 2014 Jan 7.

2) Ludvigsson Mikael, Marcusson Jan, Wressle Ewa, Milberg Anna. Markers of subsyndromal depression in very old persons. Int J Geriatr Psychiatry. 2016 Jun;31(6):619-28. doi: 10.1002/gps.4369. Epub 2015 Oct 21.

3) Ludvigsson Mikael, Bernfort Lars, Marcusson Jan, Wressle Ewa, Milberg Anna. Direct costs of very old persons with subsyndromal depression: a five-year prospective study. Am J Geriatr Psychiatry. 2018 Jul;26(7):741-751. doi: 10.1016/j.jagp.2018.03.007. Epub 2018 Mar 15.

4) Ludvigsson Mikael, Marcusson Jan, Wressle Ewa, Milberg Anna. Morbidity and mortality in very old persons with subsyndromal depression: An eight-year prospective study. Submitted. 


\section{Förord}

Sedan lång tid har jag personligen haft ett engagemang för äldre personer, och mer specifikt för äldre personer med psykisk ohälsa med bl a depressiva tecken. Jag är inte helt klar över ursprunget till detta engagemang, men kanske har mitt grundläggande sociala patos bidragit till detta engagemang, då jag återkommande upplevt att gruppen äldre personer (jämfört med yngre personer) och gruppen personer med psykisk ohälsa (jämfört med kroppslig ohälsa) systematiskt har förbisetts eller förringats vid planerande och utformande av samhällsliv och sjukvård. Jag har engagerat mig i detta ämne och dessa personer genom mitt arbete som specialistläkare inom geriatrik, och genom min efterföljande specialisering inom allmänpsykiatri, inklusive egen psykoterapi till patienter.

När jag genomförde min första intervjustudie $\mathrm{i}$ ett urval av äldre personer noterade jag särskilt hur svarsbias vid skattningsskalor eller anamnestiska intervjuer försvårade tolkningen, vilket väckte mitt intresse. Inte bara fysisk samsjuklighet och transkulturella aspekter komplicerade min tolkning av psykiatriska tecken och symtom under samtalen, utan även den detaljen att äldre personer (liksom även yngre personer) ibland förnekade depressiva symtom som svar på mina frågor, samtidigt som de ändå kommunicerade sådana symtom genom deras alternativa formuleringar och genom icke-verbal kommunikation och kroppsspråk. Om jag exempelvis frågade om de upplevde ihållande nedstämdhet, så svarade de kanske "nej, men däremot kanske ibland dysterhet", samtidigt som kroppsspråket tydligt talade för ett aktuellt sänkt stämningsläge som vid depressivitet. Vid en ordagrann tolkning hade dessa svar som ett exempel på svarsbias tolkats som nekande av nedstämdhetsfrågan, medan kommunikationen vid en mer öppen tolkning (inklusive den övriga icke-verbala kommunikationen) istället bekräftade nedstämdhet.

Vid närmare studier om depressiva tecken och lindrig depressivitet hos äldre personer kom jag, förutom svarsbias, så småningom i kontakt med begreppet subsyndromal depression. Det väcktes inom mig därvid ett intresse för att bättre förstå gränssnittet mellan egentlig eller syndromal depression och det normala åldrandet. Någon kollega varnade mig för att försöka forska i detta område av så diskreta sjukdomstecken, eftersom det därmed skulle vara nästan som att "forska på fantomer" (d.v.s. svårt att mäta fantomer eller spöken, eftersom sådana inte har någon fysisk kropp [min personliga tolkning av kollegans varning]). Emellertid blev jag senare stärkt i mina föresatser att forska på subsyndromal depression hos äldre personer, efter samtal med en senior äldrepsykiatrisk läkare som istället utifrån sina erfarenheter betonade de subsyndromala tillståndens stora kliniska relevans i arbetet för att kunna hjälpa och behandla äldre personer med psykisk ohälsa [1]. Viljan att hjälpa äldre personer med psykisk ohälsa genom att bidra till vetenskaplig utveckling ledde mig så småningom vidare till detta avhandlingsprojekt.

I början av denna avhandling citeras en dikt av Walt Whitman, vilken har valts ut för att den enligt min tolkning påminner om hur vi människor ofta tenderar att komplicera livet alltför mycket, genom exempelvis dysfunktionella tankemönster, missförstånd och konflikter. Denna 
tendens att komplicera saker i livet alltför mycket leder i sina konsekvenser bl a till olika former av psykisk ohälsa, eller rentav - som i Whitmans dikt - till död.

Kaptenen i dikten, vilket i min tolkning skulle vara kaptenen för oss själva (jaget, eller frontalloben av hjärnan) och våra värden, ligger på däck eftersom vi inte har tilldelat hen ett berättigat ledarskap i livet. Istället låter vi ofta tillfälliga impulser, dysfunktionellt tänkande och yttre omständigheter få ledarskapet i våra liv, medan kaptenen får stå åt sidan. Om vi istället skulle ge tillbaka ett berättigat ledarskap till kaptenen i livet och inte komplicera saker så mycket, så skulle vi förmodligen lida mindre av psykisk ohälsa och istället kunna njuta av livets färd ännu mer. Om vi således kunde förebygga psykisk sjukdom och istället leva ett mer meningsfullt liv, så skulle vi kanske kunna stå tillsammans med huvudpersonen i dikten - nära hamnen - och ta del av klockorna och människornas glädje.

Avhandlingen är primärt skriven på engelska, men denna svenska version finns med som bilaga till avhandlingen för att underlätta spridningen till potentiella läsare. 


\section{Introduktion: Depression, subsyndromal depression (SSD) och äldre äldre personer}

\subsection{Depression och psykiatriska diagnoser historiskt}

Depression eller Melankoli var ett tillstånd som beskrevs redan i antikens dagar, och läkekonstens grundare Hippokrates (460-370 f.v.t.) beskrev då att "om fruktan eller nedstämdhet varar länge, så kallas det för melankoli”, och att melankoli var orsakat av ett överskott på svart galla i relation till de övriga tre kroppsvätskorna (gul galla, blod och slem; figur 1)[2]. Några århundraden senare vidareutvecklade Galenos (129 v.t. - ca. 200/ca. 216) denna humoralpatologiska lära om hur olika sjukdomstillstånd var orsakade av exempelvis obalans mellan kroppsvätskorna, vilket under många århundraden ledde till behandlingar mot melankoli med bl a örter för att återskapa balans i kroppen [3, 4]. Även om t ex Carl von Linné i Sverige gjorde en ansats att klassificera psykisk sjukdom på 1700-talet, så levde humoralpatologin i teori och praktik kvar ända fram till 1800-talet [5].

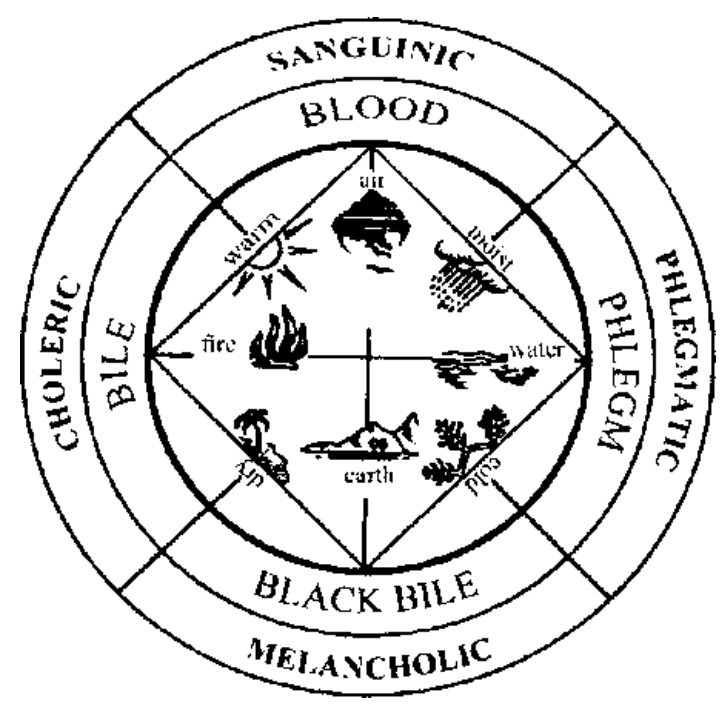

Figur 1. Schematisk bild av den humoralpatologiska synen på depression eller melankoli. Från Schipperges 1970, enligt Bujalkova M et al 2001 [6] med tillstånd. 
Sedan dess har den psykiatriska diagnostiken vidareutvecklats av kliniker och tänkare som bl a Sigmund Freud (1856-1939) och Emil Kraepelin (1856-1926). Freud grundade psykoanalysen i början av 1900-talet, och den jämnårige Kraepelin grundade lite tidigare i sina skrifter den moderna sjukdomsläran inom psykiatrin, vilken i hög utsträckning motsvarar en strävan mot systematiskt empiriskt kartläggande av psykiatriska symtom och upplevande över tid [2]. År 1952 publicerade American Psychiatric Association den första upplagan av diagnosregistret Diagnostic and Statistical Manual: Mental Disorders (DSM-I) om psykiatriska störningar, vilket byggde på Freuds psykoanalytiska grunder. Parallellt med diagnosregistret DSM inom psykiatrin, så fanns även diagnosregistret ICD (International Classification of Diseases)[7] mer generellt täckande av både psykisk och somatisk sjukdom, och den andra reviderade versionen av DSMregistret år 1968 var en omarbetning som närmade sig strukturen för ICD-registret och de kroppsliga sjukdomarna. Den tredje versionen av DSM som utarbetades under 1970-talet var en radikal omarbetning som byggde på de s.k. Feighner-kriterierna för depression, utifrån en strävan efter validitet och reliabilitet snarare än teorier om etiologi, och fortfarande idag med den nuvarande femte versionen av DSM-registret så används dessa Feighner-kriterier relativt oförändrat [8-11].

För diagnosen depression bestämdes i DSM-III (motsvarande de s.k. Feighner-kriterierna): att det ihållande, under minst två veckor, måste föreligga minst 5 av följande 9 symtom: nedstämdhet, förlust av intresse eller glädje, påverkad aptit eller kroppsvikt, sömnstörning, psykomotorisk påverkan, energibrist, skuldkänslor eller mindervärdestankar, svårigheter med koncentration eller tankeförmåga, återkommande tankar på eller längtan efter död. Dessa symtom och tecken tillsammans kallas således för det psykiatriska syndromet eller sjukdomskomplexet depression. Robins och Guze, två medarbetare till Feighner, kritiserade det då rådande psykoanalytiska paradigmet och gjorde en mer noggrann beskrivning av validitetskonceptet inom psykiatrisk diagnostik, vilken blev tongivande för omarbetningen av DSM-registret [12, 13]. Deras modell för att validera diagnoser byggde på $5 \mathrm{steg}$ (varav Feighnerkriterierna ingår i det första): 1) kliniska karakteristika för syndromet (inklusive symtom, demografiska karakteristika, mm), 2) exklusionskriterier för att differentiera mot andra syndrom, 3) familjehistoria, 4) laboratoriedata och 5) uppföljning (tidsförlopp av besvären, behandlingssvar).

Diagnoskriterier har varit uttryck för en strävan att reliabelt beskriva och definiera vad sjukdomen eller störningen depression innebär, och Feighner-kriterierna för depression i DSMregistret har sedan dess betraktats som en gold standard för depressionsdiagnostik i olika avseenden. De har även i platonisk anda beskrivits som verklighetens skugga av ett ideologiskt koncept, eller som våra empiriska indikatorer av den bakomliggande psykiska störningen [14]. En förenklad illustration av hur begreppen Depression eller melankoli och SSD har utvecklats i historien ges i Figur 2. 


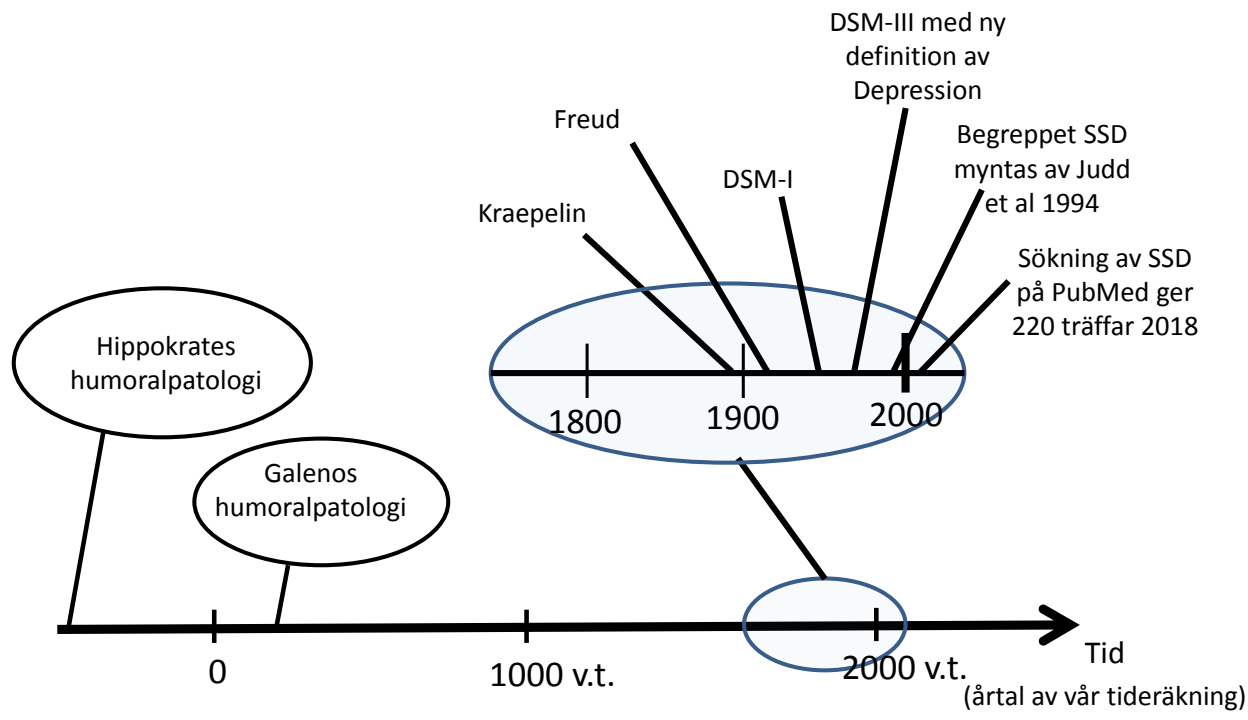

Figur 2. Depression eller melankoli, och SSD ur ett västerländskt idéhistoriskt perspektiv.

En återkommande akademisk debatt i fråga om psykiatriska sjukdomar har varit hur olika grader av störning inom ett tillstånd förhåller sig till normalitet respektive till andra störningar. Diagnosregistren DSM-5 [10] och ICD-10 [7] som administrativt används i Sverige idag utgår båda från ett kategoriskt perspektiv i vilket diagnoser förhåller sig fristående från varandra, ungefär som hinkar bredvid varandra. Ett alternativt perspektiv på psykiatrisk sjukdom är det dimensionella perspektivet, i vilket man menar att varje psykiskt tillstånd förhåller sig till normalitet eller andra psykiska sjukdomar som olika grader av besvär i olika dimensioner eller kvaliteter [14-16]. Jämförelsen mellan det kategoriska och det dimensionella perspektivet av depressiva tillstånd är illustrerat i figur 3. 


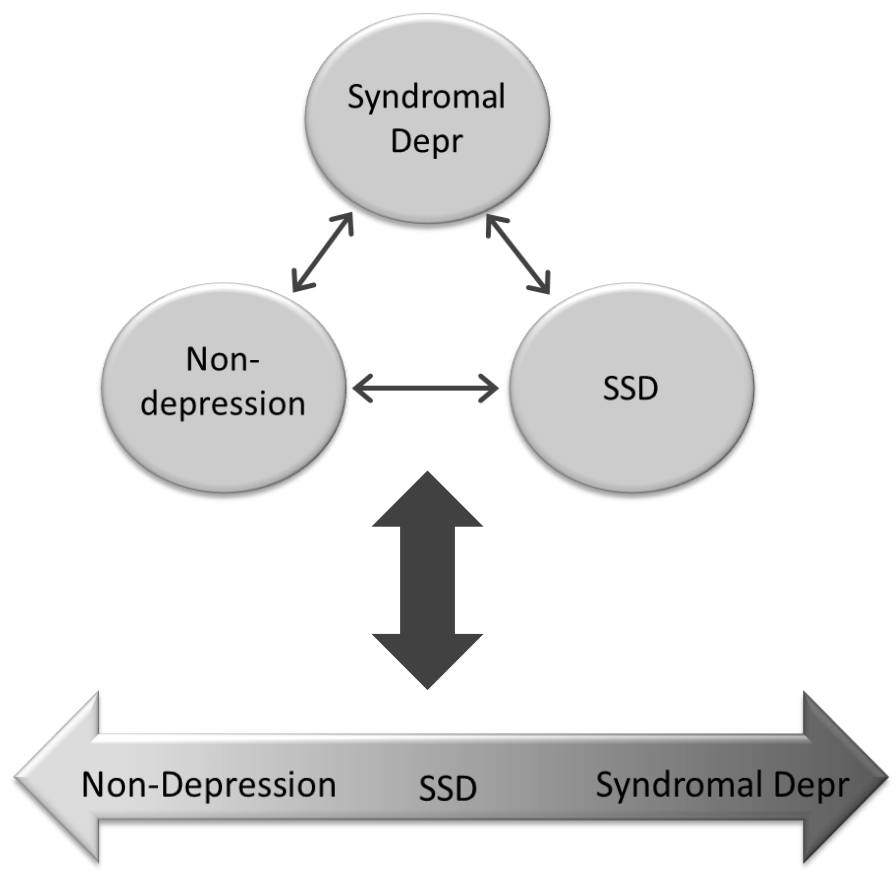

Figur 3. Schematiska skillnader mellan det kategoriska (överst) och det dimensionella (nederst) perspektivet på depressiva tillstånd.

\subsection{Subsyndromal depression (SSD): ursprung och definitioner}

I den fjärde DSM-versionen som publicerades 1992 urskilde man förutom syndromal depression tre extra subgrupper av depressivitet som kallades dystymi, mindre (minor) depression och återkommande kortvarig depression (RBD, recurrent brief depression). Därtill beskrev Judd och kollegor 1994 något som de kallade Subsyndromal symtomatisk depression, vilket sedermera kommit att kallas Subsyndromal depression mer kortfattat [17, 18]. Judd et al 1994 definierade tillståndet initialt som "minst 2 depressiva symptom, frånvaro av kärnsymtomen nedstämdhet och anhedoni, och duration minst 2v, samt signifikant lidande eller funktionsnedsättning [17, 19]. Senare har man dock prövat alternativa definitioner och operationaliseringar, och möjligen som konsekvens av att American Psychiatric Association valt att ännu inte definiera och införliva SSD i diagnosregistret DSM så har SSD med tiden blivit definierat på väldigt olika sätt i forskningen med åtföljande variation av prevalens, associerade faktorer och effekter [20-22]. Tabell 1 visar en sammanställning av hur olika depressiva tillstånd definieras i DSM-5, och hur SSD definieras i kontrast till ND eller normalt åldrande i denna avhandling. 
Tabell 1. Sammanställning av hur olika depressiva störningar definieras i diagnosregistret DSM5, samt hur SSD definieras i denna avhandling, i kontrast till ND eller normalt åldrande.

\begin{tabular}{|c|c|c|c|}
\hline $\begin{array}{l}\text { Diagnos av olika depressiva } \\
\text { tillstånd }^{\mathrm{a}}\end{array}$ & Symtomkriterier & $\begin{array}{l}\text { Duration av } \\
\text { symtom }\end{array}$ & $\begin{array}{l}\text { Övriga } \\
\text { diagnoskriterier }\end{array}$ \\
\hline $\begin{array}{l}\text { Syndromal eller egentlig } \\
\text { depressiv episod }\end{array}$ & $\begin{array}{l}\text { Minst } 5 \text { av } 9 \\
\text { depressiva symtom, } \\
\text { varav } 1 \text { av } \\
\text { kärnsymtomen } \\
\text { nedstämdhet eller brist } \\
\text { på intresse/glädje }\end{array}$ & $\begin{array}{l}\text { Mestadels av } \\
\text { dagen, nästan } \\
\text { varje dag under } \\
\text { minst } 2 \text { veckor }\end{array}$ & $\begin{array}{l}\text { Orsakar signifikant } \\
\text { lidande eller } \\
\text { funktionsnedsättning, } \\
\text { och besvären } \\
\text { förklaras inte bättre } \\
\text { av annan diagnos. }\end{array}$ \\
\hline $\begin{array}{l}\text { Återkommande kortvarig } \\
\text { depression }^{\text {b }}\end{array}$ & $\begin{array}{l}\text { Minst } 5 \text { av } 9 \text {, varav } 1 \\
\text { av ovanstående } \\
\text { kärnsymtom }\end{array}$ & $\begin{array}{l}\text { Duration 2-13 } \\
\text { dagar per } \\
\text { månad, under } \\
\text { minst } 12 \\
\text { konsekutiva } \\
\text { månader. }\end{array}$ & Ibidem \\
\hline $\begin{array}{l}\text { Ihållande depression } \\
\text { (dystymi) }\end{array}$ & $\begin{array}{l}\text { Minst } 3 \text { av } 7 \text { symtom, } \\
\text { varav ett måste vara } \\
\text { nedstämdhet }\end{array}$ & Duration 2 år & Ibidem \\
\hline $\begin{array}{l}\text { Depression utan närmare } \\
\text { specifikation, mild eller } \\
\text { måttlig svårighetsgrad }\end{array}$ & $\begin{array}{l}\text { Minst } 2 \text { depressiva } \\
\text { symtom }\end{array}$ & Ej specificerat & Ibidem \\
\hline SSD enligt Judd et al 1994. & $\begin{array}{l}\text { Minst } 2 \text { depressiva } \\
\text { symtom, och frånvaro } \\
\text { av kärnsymtomen } \\
\text { ovan }^{c}\end{array}$ & $\begin{array}{l}\text { Mestadels av } \\
\text { dagen, nästan } \\
\text { varje dag under } \\
\text { minst } 2 \text { veckor. }\end{array}$ & Ibidem \\
\hline SSD i DSM-5, ej omnämnt & Ej specificerat & Ej specificerat & Ej specificerat \\
\hline $\begin{array}{l}\text { SSD såsom definierat i } \\
\text { denna avhandling }\end{array}$ & $\begin{array}{l}\text { Specifikt } \\
\text { poängintervall från } \\
\text { resultatet av skalan } \\
\text { GDS-15 }\end{array}$ & Ej specificerat & Ej specificerat \\
\hline $\begin{array}{l}\text { ND eller normalt åldrande } \\
\text { såsom definierat i denna } \\
\text { avhandling. }\end{array}$ & $\begin{array}{l}\text { Specifikt } \\
\text { poängintervall från } \\
\text { resultatet av skalan } \\
\text { GDS- } 15^{\mathrm{d}} \text {. }\end{array}$ & Ej specificerat & Ej specificerat \\
\hline \multicolumn{4}{|c|}{$\begin{array}{l}\text { Anmärkningar: }{ }^{a}=\text { Jämfört med DSM-5 har följande diagnoser utelämnats från tabellen i syfte att } \\
\text { förenkla framställningen: dysforiskt syndrom med debut under barndom och tonår, } \\
\text { premenstruellt dysforiskt syndrom (PMS), substans-/läkemedelsbetingad depression, depression } \\
\text { orsakat av annat medicinskt tillstånd, andra specificerade depressioner (förutom återkommande } \\
\text { kortvarig depression), och ospecificerad depression. }{ }^{b}=\text { Detta tillstånd ingår i DSM-5 i gruppen } \\
\text { "andra specificerade depressioner". }{ }^{c}=\text { Specifikationen frånvaro av kärnsymtom (av Judd et al } \\
\text { 1994) gjordes i ljuset av att den liknande diagnosen Mindre depression innebär närvaro av minst } \\
\text { ett kärnsymtom. I den senaste versionen av DSM så utelämnades dock diagnosen mindre }\end{array}$} \\
\hline
\end{tabular}


depression. ${ }^{d}=$ Skattningsskalan GDS-15 (15-frågeversionen av Geriatric Depression Scale) beskrivs närmare i metodkapitlet, stycke 3.3.

Generellt baseras definitioner eller operationaliseringar av SSD ofta på endera symtomskattningsskalor eller strukturerade intervjuer (eller bägge delar i s.k. tvåfas-förfarande av diagnostiken), vilka tenderar att ge lite olika mätresultat inklusive olika prevalenstal [23]. Exempelvis definierades eller operationaliserades SSD som 1-5p vid skattning med GDS-15 [24] i Chachamovic et al, medan det operationaliserades med endera skattningsskala eller alternativ diagnostisk strukturerad intervju i Lyness et al [20, 25]. Skattningsskalor har generellt vissa fördelar jämfört med strukturerade intervjuer då de är enklare att administrera och ligger närmare det dimensionella perspektivet av psykiska störningar, medan strukturerade intervjuer generellt å andra sidan är bättre på att fånga tidsutveckling av symtom samt samsjuklighet [26]. Andra faktorer som påverkar prevalenstalen mycket inom psykiatrisk epidemiologi är förutom operationaliseringssätt även valen av urvalsgrupper och exklusionskriterier eftersom det generellt föreligger en hög grad av samsjuklighet eller samvariation av olika psykiatriska sjukdomar [16, 27].

Prevalensen av SSD bland äldre personer varierar kraftigt mellan olika studier (mellan 4.0 och 22.9\% punktprevalens i befolkningen enligt Meeks et al, 2011) [21], och mönstret från olika mätningar med symtomskattningsskalor är naturligt nog att prevalensen av SSD är större, ju färre och mildare symtom eller ju lägre tröskel man använder som inklusionskriterium i respektive studie. Man har i psykiatrin liksom i somatisk sjukvård även kallat dessa milda störningar för subklinisk sjukdom, och en tanke som framförts är att man i ett populationsperspektiv bör studera även de subkliniska formerna för att inte missa en viktig del av sjukdomsentiteten som helhet när man försöker att förstå och förebygga medicinska tillstånd [28, 29].

I jämförelse med andra medicinska sjukdomar där man också, trots proportionerligt växande hälsoeffekter med grad av sjukdom, har valt en kategorisk diagnostisk indelning ( $\mathrm{t}$ ex diabetes, hypertoni, hyperlipidemi), så är en principiell skillnad att man inom området depressivitet inte har någon konsensus beträffande måttstock varför frågan om cut-off för diagnosticering blir mer svårbesvarad vid depressivitet än vid de övriga tillstånden. För depressivitet liksom för de ovan nämnda medicinska tillstånden finns dock en liknande problematik av godtycklighet i beslutet om cut-off för diagnosgräns, och en åtföljande proportionerlig risk för medikalisering/överbehandling respektive underbehandling [30]. Nästan oavsett var man har bestämt cut-off mellan ND och SSD, eller mellan SSD och syndromal depression, så har ett återkommande mönster varit att SSD är associerat med nedsättning av olika funktioner och livskvalitet på en nivå mellan dem för ND och syndromal depression [21, 31]. Exempelvis är produktionsförluster i arbete, kognitiva prestationer, grad av ångest, livskvalitet och risken för framtida depression för personer med SSD på en nivå mellan personer med ND och depression [25, 32-37]. 


\subsection{Det normala åldrandet}

Även om åldrandet biologiskt ur vissa perspektiv börjar redan vid ca 30 års ålder, så brukar de ackumulerade åldrandetecknen ofta överskrida kroppsliga buffertmarginaler på ett mätbart sätt först vid 60-70 års ålder [38]. Det centrala nervsystemets åldrande syns genom bland annat en minskad hjärnvikt anatomiskt, ett minskat cerebralt blodflöde, inlagring av amyloida plack och neurofibriller på cellulär nivå, och neurokemiskt genom färre dopaminreceptorer och muskarinerga receptorer [39-41]. I sina konsekvenser leder dessa och andra förändringar till funktionsnedsättningar av kognitiva förmågor, men även av bland annat konativa (viljemässiga) och emotionella funktioner $[42,43]$. Gränsen mellan normalt åldrande och demenssjukdom är diffus, och sjukdomsförändringar som vid demenssjukdom föreligger ofta i mindre grad även vid normalt åldrande $[39,44]$

Förutom de biologiska förändringarna är åldrandet förenat med psykosociala förändringar som också påverkar det psykiska måendet, exempelvis vid sorgereaktioner pga förluster av vänner eller förluster av fysiska funktioner, vid svårare ekonomiska villkor efter pensionering, vid social isolering eller vid ansträngningen att behöva vårda eller sörja för sina nära och kära [45]. På detta sätt är ålderdomen en livsperiod som naturligt innehåller många utmaningar, vilket förklarar att många bär på föreställningen att detta är en del av livet med mycket negativa upplevelser och känslor. Emellertid finns det flertaliga studier som visat att hälsoupplevelsen eller livskvaliteten i genomsnitt på populationsnivå faktiskt inte är så dålig under ålderdomen. Även om graden av livskvalitet i ett livsloppsperspektiv på populationsnivå sjunker med ålder efter en topp vid ca 6580 års ålder, så sjunker den aldrig så lågt som till nivån för personer mellan 40-60 års ålder [46, 47]. Det faktum att livskvaliteten eller välmåendet alltså tvärtom är relativt hög på populationsnivå under ålderdomen jämfört med andra perioder i livet trots att det normala åldrandet innehåller så många förluster och utmaningar, har kallats för hälsoparadoxen under åldrandet [48].

Exakt vad som kan förklara hälsoparadoxen under åldrandet är inte känt, men ett ämnesområde som bär på förklaringsvärde är litteraturen om copingprocesser och resilience. Coping står för människors ansträngningar av olika slag att komma till rätta med svårigheter i livet, medan resilience likartat handlar motståndskraft eller förmågan att återhämta sig efter stress [49-56]. Resilience har i vetenskapliga studier undersökts i äldre urval och bland annat visat sig vara associerat med lägre grad av depressivitet, minskad mortalitet [57-59]. Det finns också andra liknande teoretiska koncept som har använts för att beskriva hälsobringande eller salutogena copingstilar och hanterande av utmaningar i livet, t ex inre styrka, hardiness, och känsla av sammanhang [50, 60, 61]. Dessa salutogena processer är mest beforskade inom disciplinerna omvårdnad, sociologi och psykologi, medan motsatt riktade patogena eller sjukdomsbringande processer å sin sida har beforskats mer inom medicinen. Förutom copingstilar på individnivå, så har man även undersökt hälsoparadoxen och livskvaliteten under åldrandet utifrån ett större makroperspektiv på kultur- eller samhällsnivå. Grovt motsvarar detta en rörelse från psykologiskt perspektiv och omvårdnadsperspektiv på individnivå till sociologiskt perspektiv där man 
beskrivit åldrandet på gruppnivå och befolkningsnivå. Några av de större teoribildningarna med sociologiska perspektiv på vad som ger hälsa och livskvalitet under åldrandet är aktivitetsteorin, disengagemangsteorin och teorin om gerotranscendens.

Aktivitetsteorin kan i korthet beskrivas som att ett gott åldrande byggs genom att individerna fortsätter att vara aktiva även under ålderdom, trots ändrade livsförutsättningar av pension och sociala förluster [62]. Genom en aktiv livsstil under hela livet kan man enligt denna teori ha en generellt hög livskvalitet även under åldrandet, trots utmaningar och ändrade livsförutsättningar. Disengagemangsteorin har i motsatt riktning beskrivit att åldrandet innebär en naturlig tendens att vilja dra sig undan socialt och engagera sig mindre i det sociala livet [62,63]. Genom att dra sig undan från yttre sociala sammanhang, och istället ägna tid åt reflexion, reminiscens (hågkomst och sammanknytande av minnen) och inre aktiviteter kan personer under åldrandet uppnå en god hälsa. Teorin om gerotranscendens har likheter med disengagemangsteorin, men involverar mer existentiella och andliga aspekter då den beskriver att personer under ålderdomen har ett ökat behov av reflektion och att det sker en personlig utveckling med överskridande $\mathrm{i}$ tre dimensioner: den kosmiska, jaget och de sociala relationerna [64]

Mycket av forskningen om salutogena faktorer i åldrandet har använt begreppet successful aging (framgångsrikt åldrande) för att beskriva vad som främjar en god livskvalitet under åldrandet och ålderdomen (även om vissa har framfört att "optimalt" åldrande skulle vara en mer kulturneutral beskrivning) [63, 65, 66]. Forskningen om successful aging tog fart under 1980- och 1990-talen genom en forskningsgrupp Mac Arthur Foundation i USA, och det teoretiska konceptet har studerats omfattande, som en del av salutogena aspekter av det normala åldrandet $[63,67,68]$. En teori som mer nyligen integrerat många delar från ovanstående olika teoretiska riktningar är teorin Integration av styrka och sårbarhet (Strength and Vulnerability Integration, (SAVI) [69]). Tillsammans ger dessa olika teorier en mer heltäckande bild av hur det är att åldras, och att leva i ålderdomen med förutsättningar som å ena sidan är gemensamma utifrån kronologisk åldersgrupp, biologisk och fysisk ålder, generation (sekulär trend) och kultur/subkultur [70-73], och med förutsättningar som å andra sidan är individuellt olika.

Även om många normala biologiska åldrandeprocesser alltså börjar tidigare i livet så är det vanligt att man för vetenskapliga studier sätter den nedre kronologiska gränsen för äldre personer vid 60 eller 65års ålder, men eftersom livet ur flertalet aspekter (socialt, psykologiskt, biologiskt) på gruppnivå förändras väsentligt även fortsättningsvis med tydliga skillnader mellan 65 år och exempelvis 85 års ålder, så har man kronologiskt valt att för vetenskapliga syften även differentiera mellan yngre äldre (60-80års ålder) och äldre äldre (eller "de allra äldsta" (80+ eller 85+ års ålder) [74, 75]. I ett psykosocialt funktionellt perspektiv har man ibland på motsvarande sätt åtskilt mellan en tredje och en fjärde ålder av livet [76]. Medan personer i den tredje åldern av livet (grovt motsvarande åldersgruppen yngre äldre) fortfarande har goda resurser fysiskt, socialt och ekonomiskt med självständighet och relativt god hälsa, så ändras förutsättningarna för personer generellt i den fjärde åldern (motsvarande äldre äldre personer) med tilltagande multisjukdom, skörhet, funktionsnedsättningar, socialt och ekonomiskt beroende, mm. Även om 
indelningen mellan den tredje och fjärde åldern av livet psykosocialt inte på individnivå måste korrelera med den kronologiska indelningen mellan yngre äldre och äldre äldre, så finns det på gruppnivå en klar och meningsfull parallell mellan dessa två indelningar.

Den aktuella demografiska utvecklingen i världen innebär att andelen äldre personer - och i synnerhet andelen äldre äldre personer - ökar stadigt, varför det finns ett växande behov av att vetenskapligt förstå och beskriva äldre personers behov och preferenser, deras tanke- och beteendemönster, samt ett behov att identifiera och beskriva associerade salutogena och patogena processer under åldrandet [74].

\subsection{Förekomst och orsaker till depressivitet hos äldre äldre personer}

Depressivitet är ett omfattande samhällsproblem, och exempelvis har beräknats att depression år 2030 kommer att vara den största bidragande faktorn till sjukdomsbörda i höginkomstländer, medan den idag är näst störst faktorn globalt, näst efter ländryggssmärta [77, 78]). På individnivå orsakar det stort lidande och konsekvenser både för psykiskt och somatiskt mående, liksom för aktivitetsförmåga $[79,80]$. Även om depressioner i många fall läker spontant utan behandling, så finns ett stort antal behandlingar som påskyndar och ökar tillfrisknade från depression med åtföljande reduktion av lidande, aktivitetsnedsättningar och sjukdom, och några vanliga alternativ för depressionsbehandling enligt aktuella medicinska riktlinjer är kognitiv beteendeterapi (KBT), interpersonell psykoterapi, antidepressiv läkemedelsbehandling, ECT (elektrokonvulsiv terapi) och fysisk aktivitet [81, 82]).

Liksom hos yngre vuxna, så är det vanligt med depressivitet eller depressiva tecken hos äldre personer. Man räknar med att mellan 1-5\% av den äldre populationen lider (12månadersprevalens) av syndromal depression i Sverige och i andra länder (möjligen med viss variation mellan länder)[83-87], medan åtminstone två till tre gånger så många lider av kliniskt signifikanta depressiva symtom eller subsyndromal depression [88-91].

Vid depression jämfört med ND bland äldre personer har man funnit förändringar både neuroanatomiskt och neurokemiskt, och depressioner i åldrandet har generellt lite annorlunda etiologi än depressioner bland yngre personer med mer organiska hjärnskador och somatisk samsjuklighet som bidrar till symtombilden [92-96]. Det har återkommande framförts att symtombilden vid depression hos äldre är annorlunda eller atypisk jämfört med den hos yngre vuxna vilket har kallats för åldersfärgning av depression, en hypotes som man i återkommande studier försökt att empiriskt bekräfta [97-99]. Exempelvis har man funnit mer kognitiva nedsättningar, högre suicidalitet och mindre nedstämdhet vid depression hos äldre jämfört med yngre [100-102]. Istället för att jämföra depression mellan olika kronologiska åldersgrupper, så har en alternativ ansats också varit att jämföra äldredepression som debuterat tidigare i livet (Early-onset depression) med depression som debuterat senare i livet (Late-onset Depression), för att på gruppnivå empiriskt kunna urskilja åldersfärgning [43, 103, 104]. Andra har argumenterat för att det faktiskt inte föreligger några större skillnader i depressioner mellan äldre och yngre 
åldersgrupper, så länge man korrigerar för samsjuklighet och metodologiska skillnader mellan studier [89, 105].

\subsection{Behandling av depressivitet hos äldre äldre personer}

Rekommendationer för behandling av depression hos äldre har generellt svagare vetenskapligt underlag än för dem vid depression hos yngre vuxna, eftersom flertalet studier genomförts i yngre åldersgrupper. Någon internationellt etablerad behandlingsmodell för behandling av SSD finns inte, vilket förmodligen beror delvis på bristen av konsensus kring definitionen av begreppet, och delvis för att det inte genomförts så många behandlingsstudier för tillståndet [21]. Tidigare studier som undersökt behandlingseffekter av SSD och lindrig depressivitet bland yngre vuxna indikerar att gängse depressionsbehandling med exempelvis KBT eller läkemedelsgruppen SSRI möjligen fungerar även för SSD, även om effektstorlekarna generellt är mindre vid SSD än vid syndromal depression [106-108]. För syndromal depression i den specifika åldersgruppen äldre äldre personer finns inte heller några särskilda riktlinjer, men däremot för äldre personer $>65$ år mer generellt [109].

Vanligt förekommande behandlingar som visat effekt bland äldre personer är bl a KBT, antidepressiva farmaka, fysisk aktivitet, collaborative care [109, 110]. Collaborative care är en metod för behandling av depressivitet, vilken är mindre vanlig i Sverige ännu så länge. Metoden innebär att sjukvården använder en så kallade vårdsamordnare (care manager) eller personligt ombud som en länk mellan den depressiva personen och övriga behandlingsgivare, vilket visat sig behandlingseffektivt och eventuellt även kostnadseffektivt [110-113].

Inom geriatrisk verksamhet har man under senare år alltmer implementerat så kallat "strukturerat omhändertagande av äldre" (Comprehensive Geriatric Assessment (CGA)), vilket motsvarar en multiprofessionell och systematisk holistisk och personcentrerad bedömning och behandling av äldre patienter [114, 115]. Sådan behandlingsmetod eller behandlingsmodell har även förordats av forskare inom forskningsområdet depressivitet hos äldre, även om det ännu inte prövats vetenskapligt som specifik behandling för depressionspatienter [116]. Ännu en modell för behandling som också förespråkats för olika grader av depressivitet beskrivs bland annat $\mathrm{i}$ brittiska nationella riktlinjer, där man generellt förordar en så kallad stepped-care modell, d.v.s. å ena sidan lågintensiva interventioner vid mindre besvär och å andra sidan mer intensiva interventioner vid större besvär i modell av en behandlingstrappa [27, 82, 117]. Både Collaborative care, CGA och stepped-care är modeller som principiellt beaktar den komplexa multifaktoriella genesen av depressivitet, vilket också beaktas i KBT inom exempelvis så kallad skräddarsydd internet-KBT [118], såväl som i farmakologiska tilläggsstrategier [119, 120]. Att beakta de komplexa och multifaktoriella aspekterna av depressivitet är vanligen rekommenderat $\mathrm{i}$ äldrepsykiatrin, eftersom detta motsvarar naturen för äldrepsykiatriska störningar [121]. Som grundregel är det i praktiken vanligt att man generellt i sjukvården väljer att extrapolera evidens för olika behandlingseffekter från depression hos yngre personer till åldersgruppen äldre äldre personer, även om detta ibland sker på svaga grunder [109, 122, 123]. 


\title{
1.6 Den komplexa zonen mellan normalt åldrande och syndromal depression
}

\author{
Sedan Hippokrates dagar har det således funnits en växande kunskap om melankoli eller
}

syndromal depression (även om relationen mellan termerna melankoli och depression förändrats över tid) [2, 124], och sedan Judd et al beskrev subsyndromal depression 1994 [17] så har man i stort antal studier beskrivit SSD eller subklinisk depression på olika sätt. Samtidigt har man i vetenskapliga studier studerat hur det normala livet, SSD och depression förändras med åldrandet. Emellertid är det generella mönstret inom ämnesområdet depressivitet liksom inom annan äldrepsykiatri och flera medicinska områden, att flertalet studier av åldrande har gjorts på åldersgruppen yngre äldre, medan få studier har gjorts på åldersgruppen äldre äldre $[21,116$, 125].

Exempelvis var det i den tidigare nämnda litteraturgenomgången av Meeks et al om SSD bland äldre personer endast $7 / 38(18 \%)$ presenterade studier där studiedeltagarna hade en medelålder över 80år [21]. Eftersom väsentliga aspekter förändras - exempelvis att såväl graden av cerebrala skador, somatisk multisjukdom och socialt beroende ökar mellan yngre äldre och äldre äldre personer - och då andelen äldre äldre personer ökar i samhället, finns ett behov av att närmare studera depressivitet i denna åldersgrupp. Med ökade kunskaper i ämnet bör man i framtiden bättre kunna avgöra hur exempelvis diagnostik och behandling bör utformas annorlunda för äldre äldre personer jämfört med yngre åldersgrupper.

SSD motsvarar en diffus och oklar zon mellan ND och syndromal depression, d.v.s. ett gränssnitt mellan å ena sidan de naturliga variationerna av normalt psykiskt åldrande och å andra sidan de sjukliga depressiva tillstånd för vilka hjälp eller sjukvård kan behövas [126]. Kritiker har beskrivit denna oklara zon mellan normalitet och patologi som att psykiatrin har misslyckats med att systematiskt anpassa diagnostikens rutiner till problemet med falskt positiva, vilket betyder att normalt intensiva reaktioner på stress felaktigt klassificeras som psykisk sjukdom i begrepp som exempelvis subsyndromal depression [127]. A andra sidan har depression beskrivits som underdiagnosticerat och underbehandlat $[128,129]$. Således leder denna oklara zon mellan psykisk hälsa och sjuklighet till både falskt positiva och falskt negativa fall, och samtidigt en parallell känsla av bristande specificitet i diagnostiken.

\subsection{Det ovan identifierade kunskapsgapet, som motiv till doktorsavhandlingen}

Sammanfattningsvis har presenterats ovan att den oklara zonen mellan syndromal depression och normalt åldrande är väsentlig för äldre personers psykiska hälsa, och att SSD som motsvarar denna oklara zon är vanligt förekommande i befolkningen. Därtill föreligger ett kunskapsgap avseende SSD i åldersgruppen äldre äldre personer, vilket framstår som särskilt viktigt mot bakgrund av den aktuella demografiska utvecklingen. 


\section{Syfte}

\section{1 Övergripande syfte}

Ett övergripande syfte för detta avhandlingsprojekt var att undersöka och beskriva det oklara området mellan syndromal depression och ND hos äldre äldre personer, d.v.s. att undersöka subsyndromal depression (SSD) hos äldre äldre personer. Genom undersökning och djupare förståelse av SSD med dess olika aspekter och komponenter, så skulle kliniker kunna ge mer adekvat prevention och behandling till de depressiva personer som har sådana behov. Genom djupare förståelse av detta oklara område, så skulle vård- och omsorgspersonal även kunna utveckla sin förmåga att bättre skilja mellan patologi och normala affektiva tillstånd i ålderdomen - att öka träffsäkerheten i diagnostik, och reducera antalet falskt positiva och falskt negativa fall.

Frågeställningar:

- Vad är SSD i relation till ND och syndromal depression bland äldre äldre personer?

- Hur ser SSD ut bland äldre äldre personer, d.v.s. hur upplever personer med SSD sin tillvaro, och vilka faktorer är associerade med SSD?

○ Vad har SSD för konsekvenser för äldre äldre personer? Skiljer sig SSD jämfört med ND eller Syndromal depression avseende sjuklighet, sjukvårdskostnader eller dödlighet?

\subsection{Specifika syften för respektive delstudie}

- Studie 1: att undersöka upplevelser av tillvaron hos äldre äldre personer med SSD, och att göra en kvalitativ jämförelse med upplevelserna bland äldre äldre personer med syndromal depression respektive ND.

- Studie 2: att i en tvärsnittsstudie undersöka associerade faktorer till SSD bland äldre äldre personer, och att utveckla en modell för prediktion av SSD bland äldre äldre personer.

På basen av tidigare litteratur och resultaten från studie 1 uppställdes hypoteser att SSD skulle vara associerat till sociodemografiska faktorer ( $\mathrm{t}$ ex kvinnligt kön, lägre utbildningsnivå), avtagande fysiska funktioner ( $\mathrm{t}$ ex problem med rörelseförmåga), eller neuropsykiatriska faktorer ( $\mathrm{t}$ ex tidigare affektiv psykiatrisk sjukdom eller kognitiv dysfunktion) [21]. Ännu en hypotes var att existentiella faktorer ( $\mathrm{t}$ ex brist på mening i livet) skulle vara associerat med SSD bland äldre äldre personer, eftersom sådana associationer tidigare visats för syndromal depression [130].

- Studie 3: att jämföra prospektiva direkta kostnader för hälso- och sjukvård respektive kommunal omsorg, och sjukvårdskonsumtion för personer med SSD jämfört ND i en population av äldre äldre personer under en femårsperiod. Ett andra syfte var att utveckla 
en modell för att predicera direkta sjukvårdskostnader bland äldre äldre personer med SSD.

På basen av tidigare litteratur om yngre åldrar hade vi hypoteser att direkta kostnader skulle vara a) högre för äldre äldre personer med SSD jämfört med ND, oberoende av somatisk multisjukdom [131, 132], och att b) faktorerna somatisk multisjukdom, nedsatt kognitiv funktion [133], nedsatt fysisk funktion och ADLförmåga [134], kronisk smärta [135], och ensamhet [136] också skulle predicera ökade direkta kostnader.

- Studie 4: Att undersöka longitudinella utfall av SSD hos äldre äldre personer.

På basen av tidigare litteratur uppställdes hypoteser att SSD jämfört med ND skulle vara associerat med lägre ADL-funktion [137], lägre subjektiv hälsa [138], lägre kognitiva funktioner [36], en högre grad av ensamhet [139], depressivitet [35], och högre dödlighet[23]. 


\section{Material \& metod}

\subsection{Populationsstudien ELSA85 och relationen till avhandlingsprojektet}

Under 2007 och 2008 genomfördes den första mätvågen av den populationsbaserade kohortstudien ELSA85 i Linköping. Studieinformation och inbjudan skickades till alla individer födda 1922 (n=650) i Linköpings kommun, med förfrågan om att delta i studien från 85års ålder och framåt [140]. Syften med studien var att skapa en evidensbaserad grund för vård och omsorg av de äldre äldre, och med delsyften att a) beskriva populationen utifrån fysiska, psykiska och kognitiva och sociala funktioner, mm; b) identifiera olika subgrupper avseende behov av sjukvård och omsorg, c) identifiera diskriminativa faktorer för att skapa en definition för gruppen "äldre med komplexa vårdbehov", samt d) följa kohorten över tid för att analysera eventuella förändringar i behoven av sjukvård och omsorg.

I den första mätvågen ingick enkätfrågor, hembesök av arbetsterapeut, samt mottagningsbesök till läkare och sjuksköterska. Enkäten innehöll frågor om demografiska data om bland annat boende och utbildning, men också instrumentet EQ-5D för att skatta självupplevd hälsa [141], frågor om läkemedelsbruk, tidigare sjukdomar, ensamhet, känsla av mening i livet, mm. Vid hembesöket ställdes frågor enligt skattningsskalan för depression GDS-15 [24], liksom olika frågor om ADLförmåga inklusive instrumentet Instrumental Activity Measure (IAM [142]), mm. Vid mottagningsbesöket genomfördes en somatisk undersökning av läkare, blodprovstagning, samt även olika kognitiva tester inklusive Mini Mental State Examination (MMSE [143]), Victoria Stroop test [144], Trail Making Test del A (TMT A [145]), och Parallella Seriella Mentala Operationer (PaSMO [146]).

Vid ett-årsuppföljningen upprepades enkätfrågor, ADL-bedömning och GDS-15, kognitiva tester, men då genomfördes också en mer omfattande undersökning av hjälpmedel och vardagsteknologi.

ELSA85-studien var initialt planerad att fortgå ett år, men frågeställningar väcktes under studiens gång vilka motiverande en förlängning av studien över tid, med nya mätvågor efter fem respektive åtta år. Föreliggande avhandling växte fram i anslutning till denna populationsstudie, och figur 4 visar hur de olika delstudierna i avhandlingen undersökt studiedeltagare ur ELSA85 i olika skeden och med delvis olika urval. 


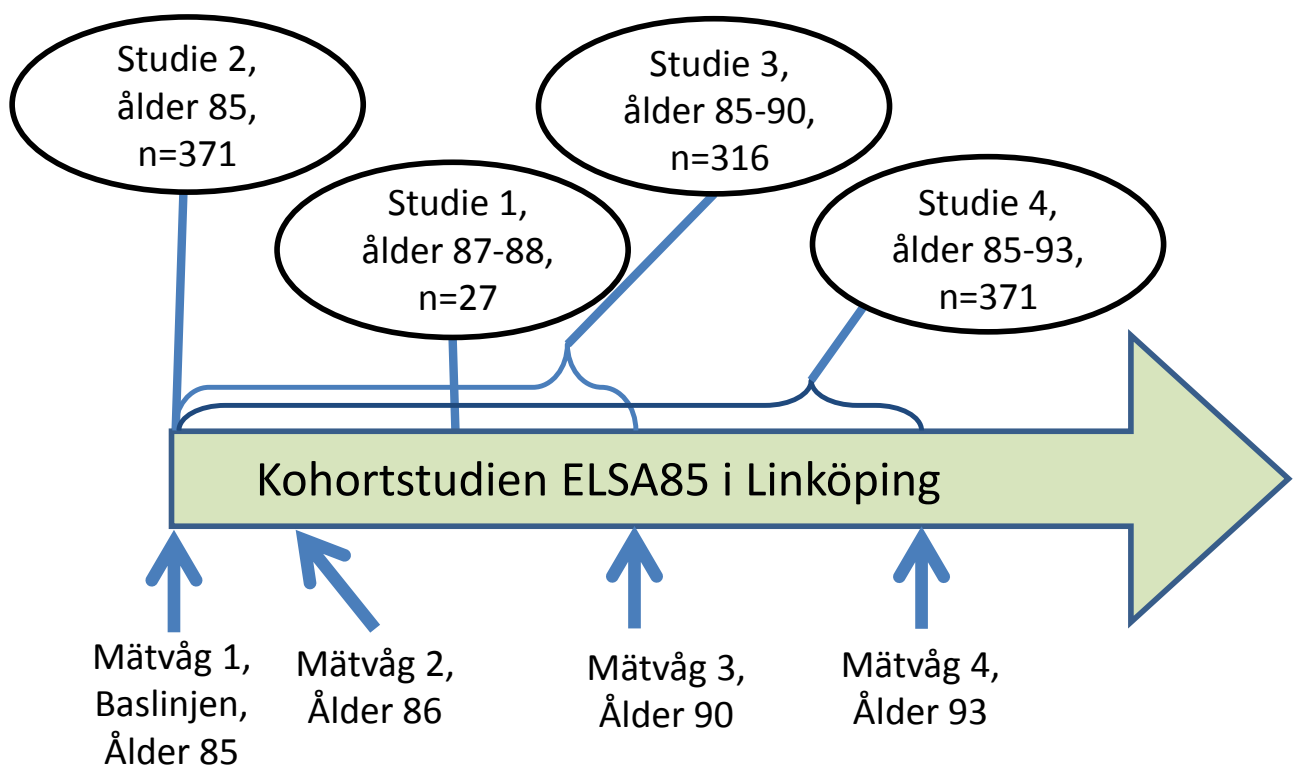

Figur 4. Schematisk figur över hur de olika delstudierna i föreliggande avhandlingsprojekt relaterar till kohortstudien ELSA85 i Linköping, 2007-2016.

\subsection{Definitioner av SSD, syndromal depression, ND och normalt åldrande för avhandlingsprojektet}

Enligt beskrivningen i introduktionen är det vanligt att man för praktiska ändamål definierar eller operationaliserar kategorier av depressivitet antingen genom strukturerad diagnostisk intervju eller med hjälp av skattningsskala. För avhandlingsprojektet operationaliserades SSD, ND och syndromal depression med hjälp av poängsumma från självskattningsskalan GDS-15 [24], vilket motsvarar ett vanligt förfaringssätt för ändamålet. Enligt exempelvis de Craen et al är det viktigt att man överväger valet av gränsdragning för en skattningsskala i enlighet med studiesyften [147], och som gräns mellan SSD och syndromal depression valdes 5/6p, vilket är en vanlig gräns som motsvarar en acceptabel sensitivitet och specificitet [148].

Som gräns mellan ND och SSD finns däremot ingen allmänt accepterad gräns, och för studie 1 valde vi 1/2p som gräns, vilket alltså innebär minst två svar indikerande depressivitet för att en deltagare skulle klassas som SSD. För studie 2-4 valdes senare istället gränsen 2/3p mellan ND och SSD eftersom denna gräns bedömdes ge bättre kriterievaliditet, och då denna högre gräns valts även i en tidigare studie [149]. Lite vägdes vid detta beslut även in hur denna gränsdragning påverkade punktprevalensen av SSD i studien. Med den lägre gränsen i GDS-15 mellan ND/SSD (1/2p) blev prevalensen SSD $50 \%$, medan den sjönk till $27 \%$ vid den senare gränsen 2/3p, vilket framstod rimligt bland annat för att bättre kunna jämföra vår studie med andra studier inom 
forskningsfältet. Normalt åldrande har för samtliga ingående studier i avhandlingsprojektet definierats vara detsamma som ND.

\subsection{Mått och mätmetod}

\section{GDS-15}

Det finns många skattningsskalor för att mäta depressivitet, och de används antingen i syfte att screena för depressiva symtom i diagnostiskt syfte eller för att följa grad av depressivitet över tid. En sådan självskattningsskala är Geriatric depression scale (GDS) med 30 frågor (GDS-30; [150, 151]), vilken konstruerades med syftet att skapa ett instrument som var bättre lämpat än andra skattningsskalor för att mäta depressiva symtom hos äldre personer.

Ett delsyfte var bland annat att skapa ett instrument där svaren skulle vara mindre beroende av förekomsten av multisjukdom och kroppsliga åldrandeprocesser än vad övriga skattningsskalor var. Ett annat delsyfte var att förenkla för personer med kognitiva funktionsnedsättningar under åldrandet att besvara frågorna, genom Ja/Nej-svar jämfört med andra mer komplexa svarsalternativ (t ex 6-gradiga ordinala svarsalternativ på enskilda frågor i andra skattningsskalor). Så småningom konstruerades även en kortversion GDS-15 (Appendix bilaga 1), eftersom GDS-30 var relativt tidsödande att använda [24]. GDS-15-skalan innehåller 15 frågor med Ja/Nej-svar, där ett poäng ges för varje fråga. Instrumentet har visat sig ha god validitet för att identifiera depression med en sensitivitet på 0.89 (95\% Konfidensitervall (CI) 0.80-0.94) och en specificitet på 0.77 (CI 0.65-0.86) vid en gräns på 5/6 p enligt en nylig metaanalys [148], och instrumentet har visat sig fungera väl även för åldersgruppen äldre äldre personer, även om man som regel bör aktivt välja gränsdragning med hänsyn till urval och syften vid sin undersökning [147].

\section{EQ-5D}

EQ-5D är ett generiskt självskattningsinstrument som värderar hälsorelaterad livskvalitet i termer av en EQ visuell analog skala (EQ-VAS), och ett deskriptivt system av de fem dimensionerna rörlighet, hygien, huvudsakliga aktiviteter, smärtor/besvär och oro/nedstämdhet [141, 152]. Var och en av de fem dimensionerna värderas i tre nivåer: inga problem, vissa problem eller svåra problem, medan EQ-VAS är en subjektiv skattning av nuvarande hälsotillstånd med ett numeriskt värde 0-100 där 0 är sämsta tänkbara, och 100 är bästa tänkbara hälsotillstånd.

\section{Somatisk multisjukdom}

Somatisk multisjukdom eller multimorbiditet operationaliserades (studie 3 och 4) som antalet kroniska sjukdomar av en författar-konstruerad förutbestämd lista av 12 sjukdomskategorier, ungefär i enlighet med rekommendationer från en litteraturgenomgång i ämnesområdet [153]: Hjärtarrytmier, hjärtsvikt eller hjärtinfarkt, annan vaskulär sjukdom, hypertoni eller hyperlipidemi, diabetes, sköldkörtelsjukdom, respiratorisk sjukdom, ledsjukdom, sjukdom i centrala nervsystemet, magtarm-sjukdom, urininkontinens respektive malignitet. 


\section{Kognitiva funktioner:}

MMSE (Mini Mental State Examination; studie 1-4) är en skala som mäter global eller övergripande kognitiv funktion med 0-30 poäng [143], och i föreliggande studier bedömdes resultat $<25$ p motsvara signifikant kognitiv dysfunktion [154].

Exekutiva funktioner mättes med Victoria Stroop test del 3 och testet Parallella Seriella Mentala Operationer (PaSMO), vilka bägge är del av det i Sverige vanligt förekommande Kognitiva screeningbatteriet $[144,146]$. För studie 2 bedömdes resultattider på >70s av Stroop-testet som exekutiv dysfunktion, och för studie 4 beräknades ett kompositmått av summan av standardpoäng från resultaten i Stroop test del3 och PaSMO.

Kognitiv snabbhet (studie 4) operationaliserades som ett kompositmått av summerade standardpoäng från resultaten av Trail Making Test part A (TMT-A; [145]) och Victoria Stroop test del 1.

\section{Ensamhet}

Ensamhet mättes med en enskild författar-konstruerad fråga (konstruerad med inspiration från tidigare litteratur [155]) om känslor av ensamhet på en skala av frekvens: aldrig, sällan, ibland eller ofta.

\section{Fysiska funktionsförmågor och aktivitetsförmågor}

Enkäten i ELSA85 innehöll ett självskattningsinstrument Instrumental Activity Measure (IAM; [142]) för att mäta instrumentella aktivitetsförmågor (activities of daily living, (I-ADL)) genom upplevda svårigheter i genomförande av åtta olika aktiviteter: förflyttning utomhus, enkel måltid, matlagning, allmänna kommunikationer, små inköp, stora inköp, städning, tvätthantering.

Svårigheterna värderades på en fyrgradig skala: för svårt, stor svårighet, viss svårighet och ingen svårighet. För studie 4 summerades dessa åtta värden till ett sammansatt summerat mått (8-32p) på I-ADL-förmåga. Personlig ADL (P-ADL) självskattades genom författarkonstruerade frågor om upplevt hjälpbehov i fyra olika aktiviteter (bad/dusch, klädning, toalettbesök och måltider) på en tregradig skala (inget, litet eller stort hjälpbehov), och dessa fyra värden summerades (studie 4) till ett sammansatt mått (4-12p) på P-ADL. Andra mått på funktionsförmågor och aktivitetsförmågor (studie 2-3) var delfrågor om huvudsakliga aktiviteter och hygien från EQ-5D (ovan), liksom användning av gånghjälpmedel.

\section{Vårdkonsumtion}

Information om antal vårdkontakter per individ för fem års tid från baslinjen inhämtades ur den regionala databasen Vårddatalagret, som innehåller information både från offentlig vård och från majoriteten av privat vård i regionen [156]. Vårdkontakterna summerades per individ, och sorterades i öppenvård och slutenvård (antal vårdtillfällen), varav öppenvård indelades i primärvård och specialistmottagning på sjukhus. Därtill registrerades även antal privata vårdkontakter separat. Av olika specialiteter urskildes särskilt psykiatrisk specialistvård. För en tabellöversikt av de olika vårdkonsumtions-komponenterna, var god se tabell 6. 


\section{Direkta kostnader för sjukvård respektive kommunal omsorg}

Information om direkta sjukvårdskostnader för fem års period från baslinjen inhämtades från databasen Kostnad per patient (KPP). KPP bygger på standardkostnader för olika vårdinsatser ( $\mathrm{t}$ ex en specifik undersökning eller kirurgisk åtgärd), och standardkostnader för olika vårdinsatser kopplas till specifika vårdkontakter. Lokalkostnader och annat som inte är bundet till den enskilda vårdkontakten distribueras över samtliga vårdkontakter. Direkta kostnader för kommunal omsorg inhämtades från databasen Kostnad per brukare (KPB) vilken räknas fram på ett liknande sätt som KPP, även om omsorgsinsatser i kontrast till vård står för boendekostnader för särskilt boende, transporter, personlig omsorg och måltider, mm. Indirekta kostnader som exempelvis produktionsbortfall, eller värdet av omsorg given av anhöriga kan också ha stor ekonomisk relevans ur ett samhällsperspektiv, men inkluderades inte analysen. Enligt metodbeskrivning för studie 3 nedan, så presenterades samtliga kostnader i valutan Euro (€).

\subsection{Design, urval och analytisk procedur i de olika studierna}

\subsubsection{Studie 1}

Ungefär två år efter baslinjen av ELSA85 kontaktades ett mindre urval av personer för en intervjustudie. För att uppnå informationsrika manifestationer av studiefenomenet valdes s.k. ändamålsenligt urval med strävan om maximal variation avseende grad av depressivitet respektive kön [157]. Inklusionskriterium var personer som uttryckt sig positiva till fortsatt deltagande även efter 1-årsuppföljningen, medan exklusionskriterier var a) samtalssvårigheter pga svårigheter med svenska språket eller uttalad tal- eller hörselnedsättning, b) kognitiv svikt på en nivå som försvårade genomförande av intervjun, samt c) kognitiv dysfunktion med $<25 \mathrm{p}$ enligt tidigare testresultat på MMSE. Informationsbrev med samtyckesblankett skickades till några personer i taget och totalt 40 personer, varav 28 samtyckte och genomgick intervju. En person exkluderades efter intervjun pga kognitiv svikt av en nivå som försvårade samtalet. Urvalsstorleken bestämdes på basen av studiesyftet och den gradvis ackumulerade informationsmängden.

En semistrukturerad kvalitativ intervju genomfördes med hjälp av intervjuguide med fyra teman (livet i allmänhet, psykologiskt mående, coping och åldrande). Dessa teman inkluderade associerade öppna frågor, såsom "Hur är det att vara 88år?"; "Vad finns det för positiva och negativa sidor?", och "Hur ser du på det förflutna/framtiden?". Dessa teman och associerade frågor tjänade som påminnelser om ämnen att täcka av, men de bestämde inte intervjustrukturen. Kompletterande och sonderande frågor ställdes också, och efter intervjun ifylldes instrumentet GDS-15 vilket sedan användes för att kategorisera deltagarna i kategorier av depressivitet. Intervjuerna spelades in och transkriberades i efterhand i sin helhet, varefter korrekturläsning och analys av textmaterialet skedde. Fältanteckningar och reflexiva anteckningar gjordes fortlöpande för att minska risken att reproducera förförståelsen, och istället öka trovärdighet för studien [157]. Analysen genomfördes i huvudsak i enlighet med latent kvalitativ innehållsanalys såsom beskrivet i Graneheim och Lundman 2004 [158], i vår studie uppdelat i sex olika steg: 1) upprepad genomläsning av unika intervjuer för att få en känsla för helheten, 2) indelning av 
texten i meningsenheter, 3) kodande av meningsenheter, 4) inom varje kategori av depressivitet (ND, SSD, och syndromal depression) abstraktion inom och mellan intervjuer genom att aggregera koder till tentativa subteman/teman (latent tolkat innehåll) respektive subkategorier/kategorier (manifest innehåll) på en högre logisk nivå, 5) inom varje kategori av depressivitet diskussion och reflexion från tentativa till mer definitiva subteman/teman, och 6) jämförande av teman och kategorier mellan SSD, ND och syndromal depression. För att möjliggöra jämförelse mellan grupperna och samtidigt undvika reproduktion av förförståelse genomfördes steg 1-3 med forskarens blindning för deltagarens tillhörighet till depressivitetskategori, medan steg 4-5 genomfördes inom varje enskild depressivitetskategori, före den slutliga jämförelsen mellan kategorierna i steg 6 . Detta förfarande, för att möjliggöra jämförelse mellan depressivitetskategorier inom ramen för kvalitativ analys, utformades med inspiration från genusteori $[159,160]$. Generellt var processen mestadels induktiv i tidigare faser, och gradvis mer deduktiv i senare faser. Analysen innehöll ett sökande efter både konvergenta dominerande mönster i texten, och även ett motsatt sökande efter avvikande eller divergenta mönster, som uttryck för en strävan mot reflexivitet [157]. Den kvalitativa innehållsanalysen är en metod som kan anpassas i enlighet med forskarnas teoretiska utgångspunkter, och i vår studie användes metoden ur ett hermeneutiskt vetenskapsteoretiskt perspektiv [161]. Som hjälpmedel i den kvalitativa analysen användes mjukvaran Nvivo version1.3.

\subsubsection{Studie 2}

För studie 2 genomfördes kvantitativ analys av data från baslinjen av ELSA85. Skattningsskalan GDS-15 besvarades av 371 personer, vilka utgjorde urval för studien (figur 5). 


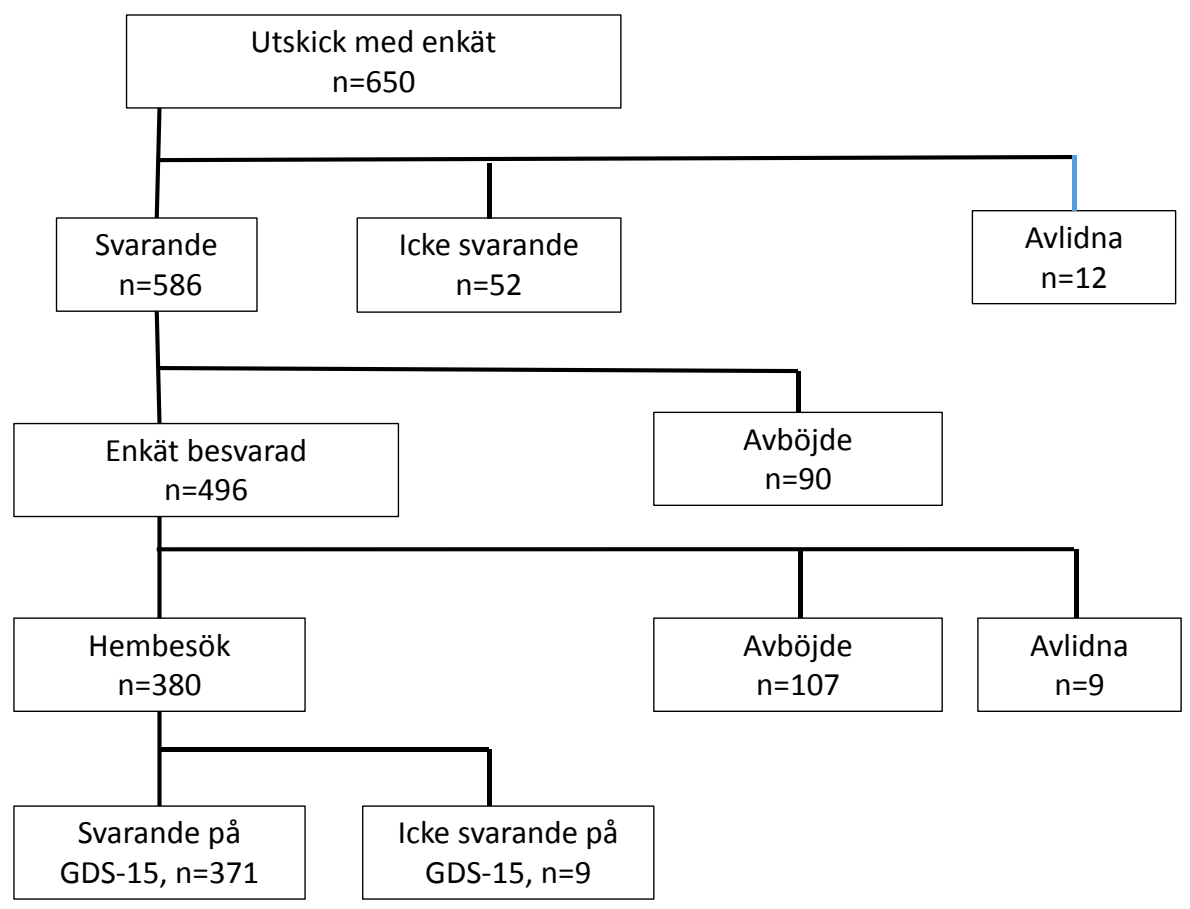

Figur 5. Härledning av urvalet som analyserades ur ELSA85-kohorten.

För analyserna användes insamlade data från såväl enkäten som hembesöket av arbetsterapeut och mottagningsbesöket till läkare och sjuksköterska. De i förväg formulerade hypoteserna (utifrån tidigare litteratur samt utifrån delstudie 1) om att SSD skulle vara associerat med faktorer inom fyra olika domäner (sociodemografiska faktorer, kroppslig nedgång, neuropsykiatriska faktorer och existentiella faktorer), operationaliserades genom 23 olika variabler (tabell 2). Bortfallet $(n=125)$ mellan besvarad enkät $(n=496)$ och svarande på GDS-15 $(n=371)$ analyserades med $\chi^{2}$-tester, och data undersöktes även för att hantera bortfall på enskilda frågor, och för att utesluta interkorrelation mellan variabler.

Enligt bakgrundsinformationen om studiedeltagarna i tabell 2 syns att det generellt fanns en omfattande sjuklighet och nedsättning av kroppsliga funktioner till följd av åldrande och sjukdomar, och även att det fanns ett generellt mönster av samvariation mellan grad av depressivitet och oberoende variabler. 
Tabell 2. Orienterande bakgrundsinformation om de svarande på GDS-15 vid baslinjen, sorterat efter kategorier av depressivitet (ND, SSD och syndromal depression).

\begin{tabular}{|c|c|c|c|c|}
\hline & & ND & SSD & $\begin{array}{l}\text { Syndr } \\
\text { Depr }\end{array}$ \\
\hline & & $\begin{array}{l}(\mathrm{n}=249) \\
\text { Antal } \\
\text { personer } \\
\text { (valid } \\
\text { procent) }\end{array}$ & $\begin{array}{l}\text { (n=99) Antal } \\
\text { personer } \\
\text { (valid } \\
\text { procent) }\end{array}$ & $\begin{array}{c}(\mathrm{n}=23) \\
\text { Antal } \\
\text { personer } \\
\text { (valid } \\
\text { procent) }\end{array}$ \\
\hline \multirow{5}{*}{$\begin{array}{l}\text { Sociodemo- } \\
\text { grafiska faktorer }\end{array}$} & Kvinnligt kön & $136(54.6)$ & $66(66.7)$ & $16(69.6)$ \\
\hline & Särskilt boende & $9(3.6)$ & $17(17.2)$ & $5(21.7)$ \\
\hline & Ensamboende & $138(55.4)$ & $59(59.6)$ & $18(78.3)$ \\
\hline & Låg utbildningsnivå & $168(67.7)$ & $70(70.7)$ & $16(69.6)$ \\
\hline & Ingen kontakt med grannar & $20(8.1)$ & $16(16.7)$ & $6(26.1)$ \\
\hline \multirow[t]{7}{*}{$\begin{array}{l}\text { Avtagande fysiska } \\
\text { funktioner }\end{array}$} & $\begin{array}{l}\text { Användning av } \\
\text { förflyttningshjälpmedel }\end{array}$ & $92(36.9)$ & $72(72.7)$ & $19(82.6)$ \\
\hline & Synnedsättning & $190(76.3)$ & $82(82.3)$ & $21(91.3)$ \\
\hline & $\begin{array}{l}\text { Huvudsakliga aktiviteter } \\
\text { (EQ-5D), vissa eller svåra } \\
\text { problem }\end{array}$ & $27(10.8)$ & $45(45.5)$ & $15(65.2)$ \\
\hline & $\begin{array}{l}\text { Hygien (EQ-5D), vissa } \\
\text { eller svåra problem }\end{array}$ & $12(4.8)$ & $26(26.3)$ & $6(26.1)$ \\
\hline & $\begin{array}{l}\text { Rörlighet (EQ-5D), vissa } \\
\text { eller svåra problem }\end{array}$ & $84(34.1)$ & $68(68.7)$ & $18(78.3)$ \\
\hline & $\begin{array}{l}\text { Smärtor/besvär (EQ-5D), } \\
\text { måttliga eller svåra }\end{array}$ & $140(56.9)$ & $68(69.4)$ & $20(87.0)$ \\
\hline & $\begin{array}{l}\text { Historia av hjärtsvikt eller } \\
\text { hjärtinfarkt }\end{array}$ & $60(24.1)$ & $32(32.3)$ & $4(17.4)$ \\
\hline \multirow[t]{7}{*}{$\begin{array}{l}\text { Neuropsykiatriska } \\
\text { faktorer }\end{array}$} & $\begin{array}{l}\text { Historia av affektiv } \\
\text { psykiatrisk sjukdom }\end{array}$ & $18(7.2)$ & $20(20.2)$ & $8(34.8)$ \\
\hline & Historia av ångeststörning & $7(2.8)$ & $11(11.1)$ & $4(17.4)$ \\
\hline & $\begin{array}{l}\text { Aktuell oro/nedstämdhet } \\
\text { (EQ-5D), vissa eller svåra } \\
\text { problem }\end{array}$ & $57(23.0)$ & $50(50.5)$ & $21(91.3)$ \\
\hline & $\begin{array}{l}\text { Användning av lugnande } \\
\text { läkemedel }\end{array}$ & $8(3.3)$ & $15(15.5)$ & $5(21.7)$ \\
\hline & Historia med Stroke & $20(8.0)$ & $22(22.2)$ & $6(26.1)$ \\
\hline & $\begin{array}{l}\text { Kognitiv dysfunktion } \\
\text { (MMSE<25p) }\end{array}$ & $27(10.9)$ & $25(25.8)$ & $7(31.8)$ \\
\hline & $\begin{array}{l}\text { Exekutiv dysfunktion } \\
\text { (Victoria Stroop test, del3 } \\
>70 \text { sek) }\end{array}$ & $58(23.3)$ & $42(42.4)$ & $12(52.2)$ \\
\hline
\end{tabular}




\begin{tabular}{|l|l|c|c|c|}
\hline $\begin{array}{l}\text { Existentiella } \\
\text { faktorer }\end{array}$ & $\begin{array}{l}\text { Subjektiv ensamhet, ibland } \\
\text { eller ofta }\end{array}$ & $74(29.4)$ & $52(52.5)$ & $20(87.0)$ \\
& $\begin{array}{l}\text { Oro för framtiden, ibland } \\
\text { eller ofta }\end{array}$ & $3(1.2)$ & $11(11.1)$ & $8(34.8)$ \\
\hline $\begin{array}{l}\text { Låg subjektiv hälsa (EQ- } \\
\text { VAS<70) }\end{array}$ & $63(26.7)$ & $72(75.0)$ & $21(91.3)$ \\
\hline $\begin{array}{l}\text { Bristande meningsfullhet } \\
\text { med livet }\end{array}$ & $17(7.3)$ & $25(27.8)$ & $13(65.0)$ \\
\hline
\end{tabular}

Association mellan förekomst av SSD (jämfört med ND respektive syndromal depression) och de fyra domäner som motsvarade våra uppställda hypoteser undersöktes först med univariata binärlogistiska regressioner och framräknande av Oddskvot (OR) med $95 \%$ konfidensintervall (CI). Därvid dikotomiserades samtliga oberoende variabler i enlighet med tabell 2. Därefter undersöktes med multivariat binärlogistisk regression hur samma uppsättning oberoende variabler var associerade med SSD, för att identifiera en möjlig prediktionsmodell för SSD.

Eftersom det sedan tidigare funnits en debatt huruvida psykiatriska tillstånd förhåller sig till normalitet eller till andra psykiatriska diagnoser kategoriskt eller dimensionellt, så valdes att förutom med binärlogistisk regression (motsvarande det kategoriska perspektivet) även analysera associationer mellan samma oberoende variabler och SSD med hjälp av ordinallogistisk respektive linjär regression. För samtliga multivariata regressioner användes stegvis automatisk selektion kompletterat med manuella stegvisa analyser, för att identifiera en möjlig modell för att kunna predicera SSD i förhållande till ND respektive syndromal depression. För de statistiska analyserna användes mjukvara SPSS version 21, och skillnader bedömdes signifikanta vid pvärden $<0.05$.

\subsubsection{Studie 3}

För studie 3 användes data från både baslinjen och 1-årsuppföljningen av ELSA85. Med insikten att depressiva tillstånd växlar mycket i intensitet över tid valdes att basera indelningen av depressivitetskategorierna på två olika mätningar, och indelningen blev enligt följande: ND vid bägge mätvågor (ND Both), SSD i endera mätvågen (SSD Ever) och syndromal depression i endera mätvågen (Depr Ever). För att lättare kunna skilja på effekter från respektive kategori beslutades för analyserna att exkludera från SSD-gruppen det fåtal individer som hade SSD vid en mätvåg och syndromal depression vid en annan mätvåg, och merparten av analyser genomfördes sammantaget på urvalet n=316 (figur 6). Direkta kostnader för sjukvård inhämtades från det nationella dataregistret Kostnad Per Patient (KPP;[162]) för fem års sjukvårdskonsumtion från baslinjen för samtliga deltagare. Därtill inhämtades information om vårdkonsumtion (antal besök, slutenvårdstillfällen, $\mathrm{mm}$ ) för samma period från det regionala dataregistret Vårddatalagret [156] i Region Östergötland, samt även direkta kostnader för kommunala tjänster från det nationella registret Kostnad Per Brukare (KPB). KPB-registret var relativt nystartat i kommunen, och kvaliteten på data bedömdes inte vara tillräckligt god förrän 
under 2011, varför kommunala kostnadsdata bara insamlades för en ettårsperiod mellan 2011 och 2012, då endast $n=270$ av urvalet $n=371$ fortfarande levde.

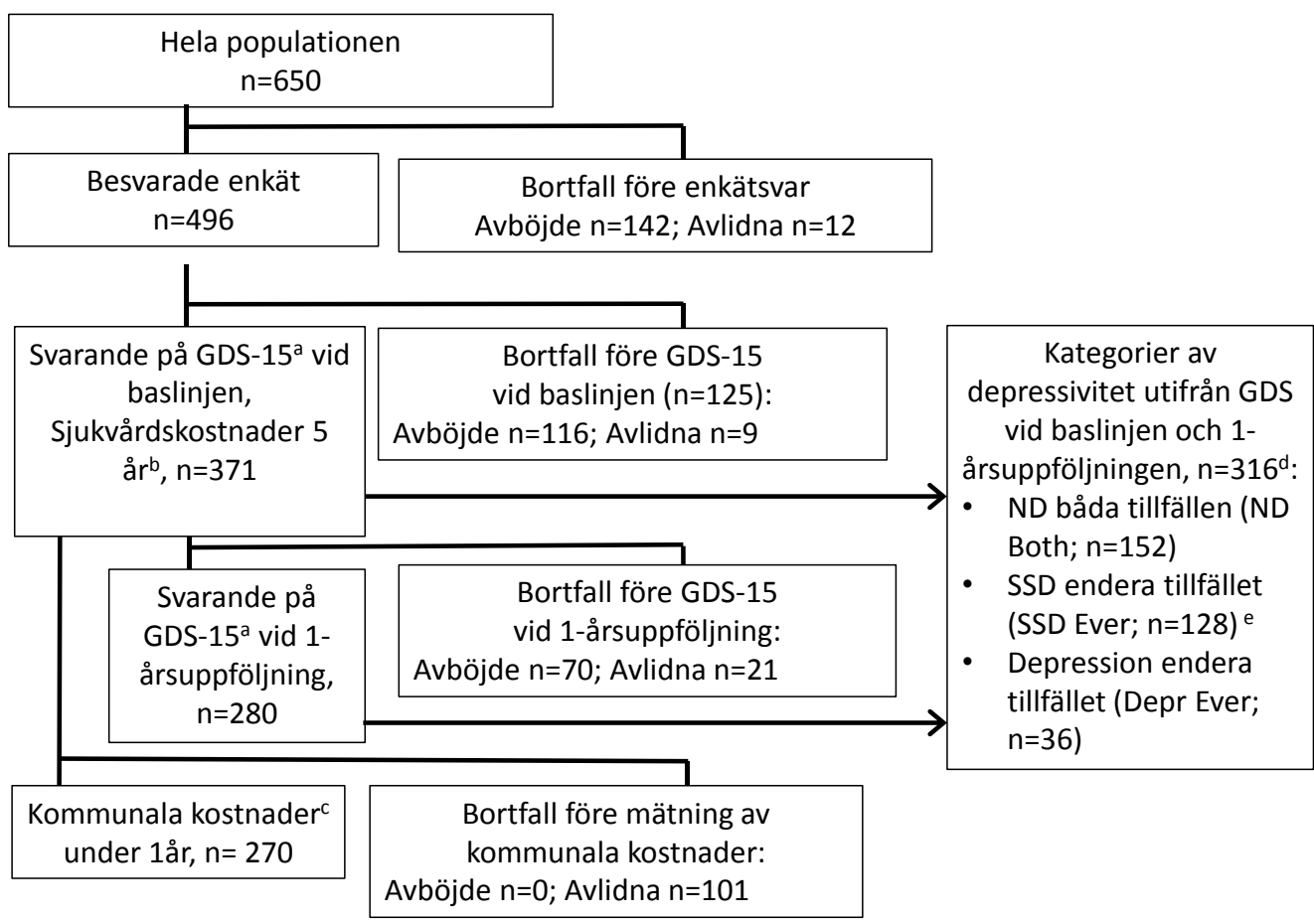

Figur 6. Härledning av urvalet från ELSA85. Anmärkningar: ${ }^{a}=$ Skattningar med GDS-15 vid intervju vid hembesök. ${ }^{b}=$ De följande åren per individ från baslinjen 2007-08 $i$ enlighet med födelsedatum. ${ }^{c}=$ Kommunala data insamlades mellan fyra och fem år efter baslinjen, under 2011-12. ${ }^{d}=$ Skillnaden mellan det analytiska urvalet $n=316$ och svarande på GDS-15 vid baslinjen bestod av de individer ( $n=55)$ som hade ND vid baslinjen, och avböjde före 1 årsuppföljningen. ${ }^{e}=$ Sexton individer motsvarade bägge kategorierna SSD Ever och Depr Ever, men för analyserna i studien exkluderades dessa personer från kategorin SSD Ever för att bättre skilja effekter per kategori.

Eftersom många deltagare avled under studieperioden gjordes analyser på kostnad per månad av överlevnad av studieperioden, och prisbelopp transformerades till Euros $(€)$ och till prisnivån vid september 2016 enligt konsumentprisindex (KPI) för att underlätta jämförelser med andra studier. Enligt rekommendationer från Statens beredning för medicinsk utvärdering (SBU) användes diskonteringsgraden $3 \%$ [163], även om känslighetsanalyser för diskonteringsgrader $0 \%$ respektive $5 \%$ också gjordes för det primära utfallsmåttet total sjukvårdskostnad per patient. 
Bortfallsanalyser genomfördes på samma sätt som i studie 1, även om vissa analyser kunde genomföras även med två-sidiga t-tester förutom med $\chi^{2}$-tester. Eftersom kostnadsdata, som i många hälsoekonomiska studier, hade en positivt skev distribution, så genomfördes analyser med Mann-Whitney U-tester, och inför linjära regressioner genomfördes logaritmisk transformering [164]. Ostandardiserade B-koefficienter med CI och p-värden uträknades, och korrigering för multipla jämförelser gjordes med metoden False Discovery Rate (FDR; [165]). Som oberoende variabler till en multipel regression valdes alla variabler enligt hypoteser, liksom kön och utbildningsnivå, och stegvis automatisk selektion för att identifiera en slutlig multipel regressionsmodell med logaritmen av totala sjukvårdskostnader som beroende variabel.

\subsubsection{Studie 4}

För studie 4 användes data från samtliga fyra mätvågor (baslinjen, 1år, 5år och 8år) av ELSA85. Liksom i många longitudinella studier av äldre äldre personer, så var det en väsentlig andel bortfall av deltagare mellan olika steg av studien [166], varför antalet personer som ifyllt GDS-15 minskade från $n=371$ vid baslinjen till $n=55$ (15\% av 371) vid 8-årsuppföljningen (figur 7).

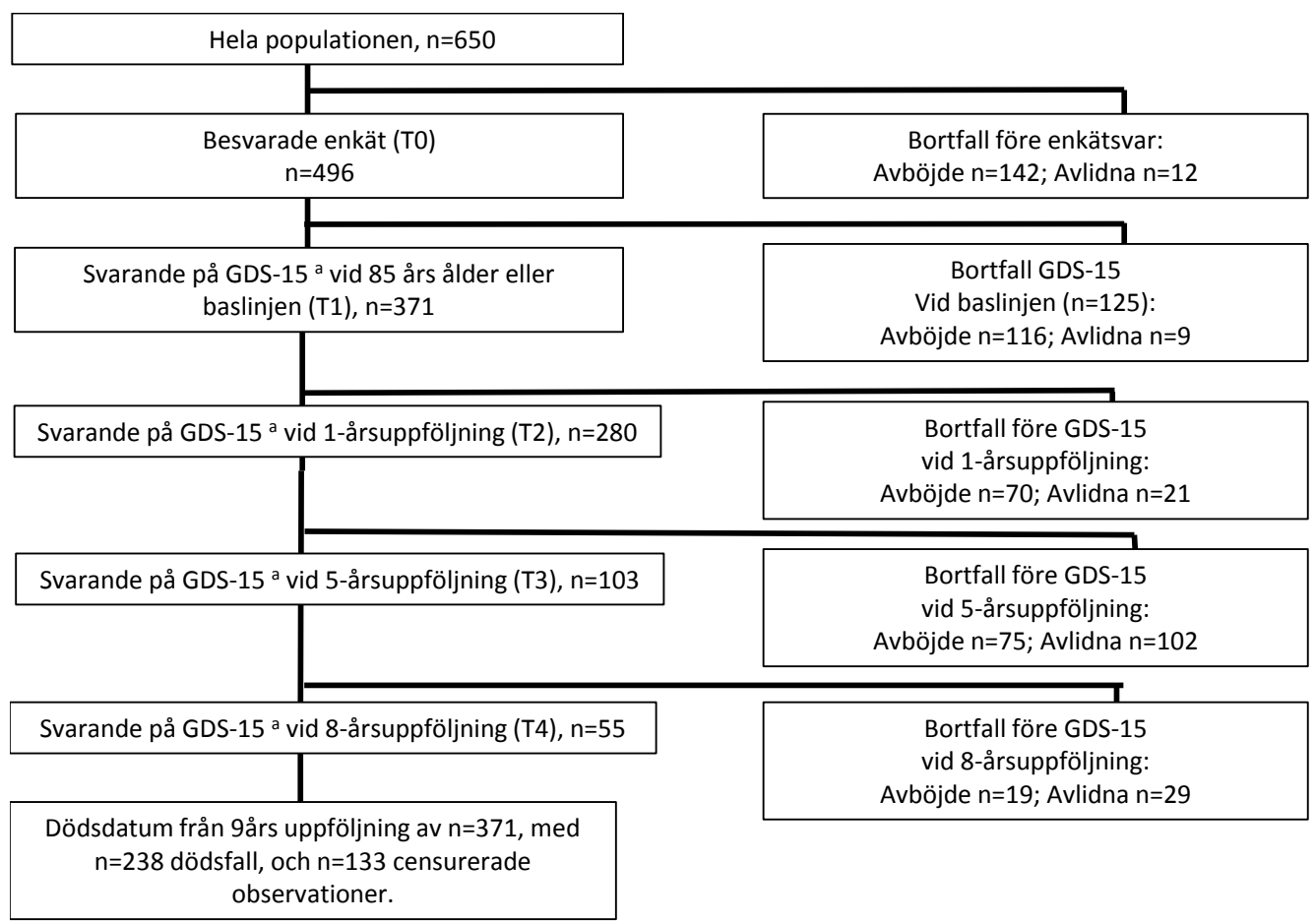

Figur 7. Urvalsprocessen från ELSA85 för studie 4. Anmärkning: ${ }^{a}=$ skattning med GDS-15 under intervju vid hembesök. 
Förutom data från ELSA85 insamlades även information om dödsdatum för respektive individ, till och med 9 år efter baslinjen. För att extrahera maximalt med information från insamlade data trots det väsentliga och icke-slumpvisa bortfallet mellan mätvågor valdes Linjär mixad modell (LMM; istället för t ex variansanalys (ANOVA) med upprepade mätningar) för de statistiska analyserna av sjuklighet, med diagonal kovarians-struktur (utifrån antagandet om autokorrelation) och med beräkning av parameter-estimater, $95 \%$ CI och p-värden $(\alpha=0.05)$ [167].

Som oberoende variabel användes SSD kontra ND med GDS-värden från samtliga mätvågor, och med korrektion för kön, somatisk multisjukdom, tid från baseline, samt ADL-förmåga.

Mortaliteten analyserades med univariata och multivariata cox-regressioner och beräkning av dödsintensitet (Hazard ratio, HR) med $95 \%$ CI och p-värden. Oberoende variabel var därvid SSD kontra ND med GDS-värden från baseline, medan överlevnadstid var beroende variabel. Bortfallsanalyser genomfördes med tvåsidiga t-tester och $\chi^{2}$-tester för deltagare som föll bort jämfört med övriga deltagare vid föregående steg i studien (tabell 3). Uteblivna svar (item nonresponse) var väsentligt för två variabler av kognitiva tester med 17 \% (64/371) bortfall för kognitiv snabbhet och $36 \%$ (132/371) för exekutiv funktion, vilket hanterades med multipel imputering före Cox-regressionen. Alla oberoende variabler motsvarande våra hypoteser, samt även kön och utbildningsnivå selekterades för den multivariata cox-regressionen med entrymodell. 
Tabell 3. Analyser med två-sidiga t-tester eller $\chi^{2}$-tester med jämförelse av deltagare som föll bort mellan varje mätvåg jämfört med övriga deltagare vid föregående mätvåg av studien.

\begin{tabular}{|c|c|c|c|c|c|c|c|c|c|}
\hline \multirow[b]{2}{*}{$\begin{array}{l}\text { Utfalls- } \\
\text { variabler }\end{array}$} & & \multicolumn{2}{|c|}{$\begin{array}{l}\text { Bortfall mellan } \\
\text { T0-T1 }(\mathrm{n}=125) \\
\text { vs övriga } \\
\text { deltagare vid T0 } \\
\quad(\mathrm{n}=371)\end{array}$} & \multicolumn{2}{|c|}{$\begin{array}{l}\text { Bortfall mellan T1-T2 } \\
(\mathrm{n}=91) \text { vs övriga } \\
\text { deltagare vid T1 } \\
(\mathrm{n}=280)\end{array}$} & \multicolumn{2}{|c|}{$\begin{array}{c}\text { Bortfall mellan T2-T3 } \\
(n=177) \text { vs övriga } \\
\text { deltagare vid T2 } \\
(n=103)\end{array}$} & \multicolumn{2}{|c|}{$\begin{array}{c}\text { Bortfall mellan T3- } \\
\text { T4 }(n=48) \text { vs övriga } \\
\text { deltagare vid T3 } \\
(n=55)\end{array}$} \\
\hline & & $\begin{array}{l}\text { Medel- } \\
\text { skillnad } \\
(\mathrm{CI}) \\
\text { eller } \chi^{2} \text { - } \\
\text { värde }\end{array}$ & $\mathbf{p}$ & $\begin{array}{l}\text { Medelskillnad } \\
\text { (CI) eller } \chi^{2}- \\
\text { värde }\end{array}$ & $\mathbf{p}$ & $\begin{array}{l}\text { Medelskillnad } \\
\text { (CI) eller } \chi^{2}- \\
\text { värde }\end{array}$ & $\mathbf{p}$ & $\begin{array}{l}\text { Medel- } \\
\text { skillnad } \\
(\text { CI) eller } \\
\chi^{2} \text {-värde }\end{array}$ & p \\
\hline $\begin{array}{l}\text { Manligt } \\
\text { kön }\end{array}$ & & $6.1^{\mathrm{a}}$ & 0.013 & 0.75 & 0.387 & 1.1 & 0.290 & 1.7 & 0.192 \\
\hline $\begin{array}{l}\text { Utbild- } \\
\text { ningsnivå, } \\
\text { antal år }\end{array}$ & & $\begin{array}{c}-0.89 \\
(-1.5- \\
(-0.30))\end{array}$ & 0.003 & $\begin{array}{c}-0.18 \\
(-1.0-0.65)\end{array}$ & 0.421 & $\begin{array}{c}-0.82 \\
(-1.8-0.11)\end{array}$ & 0.084 & $\begin{array}{c}-1.2 \\
(-2.7-0.40)\end{array}$ & 0.142 \\
\hline $\begin{array}{c}\text { Särskilt } \\
\text { boende vid } \\
\text { föregående } \\
\text { mätvåg }\end{array}$ & & $11^{b}$ & 0.001 & $7.8^{\mathrm{b}}$ & 0.005 & $4.0^{\mathrm{b}}$ & 0.046 & $5.3^{b}$ & 0.021 \\
\hline $\begin{array}{l}\text { Somatisk } \\
\text { multi- } \\
\text { sjukdom }\end{array}$ & $\begin{array}{c}\text { Antal } \\
\text { sjukdomar }\end{array}$ & $-{ }_{-}^{c}$ & --- & $\begin{array}{c}-0.44 \\
(-0.80- \\
(-0.084)\end{array}$ & 0.016 & $\begin{array}{c}0.37 \\
(-0.015-0.75)\end{array}$ & 0.059 & $\begin{array}{c}0.018 \\
(-0.60-0.63)\end{array}$ & 0.953 \\
\hline \multirow[t]{2}{*}{$\begin{array}{l}\text { Funktions- } \\
\text { förmågor }\end{array}$} & P-ADL & $--^{c}$ & --- & $\begin{array}{c}-0.44 \\
(-0.77- \\
(-0.11))\end{array}$ & 0.009 & $\begin{array}{c}-0.36 \\
(-0.61- \\
(-0.11))\end{array}$ & 0.005 & $\begin{array}{c}-0.94 \\
(-1.5- \\
(-0.36))\end{array}$ & 0.002 \\
\hline & I-ADL & $--^{c}$ & --- & $\begin{array}{c}-2.3 \\
(-4.0-(-0.51)\end{array}$ & 0.012 & $\begin{array}{c}-4.0 \\
(-5.6-(-2.5))\end{array}$ & $<0.001$ & $\begin{array}{c}-6.1 \\
(-8.8-(-3.4)\end{array}$ & $<0.001$ \\
\hline $\begin{array}{l}\text { Subjektiv } \\
\text { hälsa }\end{array}$ & EQ-VAS & $\begin{array}{c}-5.4 \\
(-11- \\
0.066)\end{array}$ & 0.053 & $\begin{array}{c}-4.4 \\
(-9.5-0.78)\end{array}$ & 0.095 & $\begin{array}{c}-2.9 \\
(-7.0-1.1)\end{array}$ & 0.148 & $\begin{array}{c}-7.5 \\
(-15-0.046)\end{array}$ & 0.051 \\
\hline \multirow[t]{3}{*}{$\begin{array}{l}\text { Kognitiva } \\
\text { funktioner }\end{array}$} & MMSE & $--^{c}$ & --- & $\begin{array}{c}-0.85 \\
(-1.9-0.23)\end{array}$ & 0.123 & $\begin{array}{c}-2.0 \\
(-2.7-(-1.2))\end{array}$ & $<0.001$ & $\begin{array}{c}-1.9 \\
(-3.1- \\
(-0.69))\end{array}$ & 0.003 \\
\hline & $\begin{array}{l}\text { Kognitiv } \\
\text { snabbhet }\end{array}$ & $--^{c}$ & --- & $\begin{array}{c}-0.14 \\
(-0.52-0.24)\end{array}$ & 0.464 & $\begin{array}{c}-0.94 \\
(-1.3-(-0.59))\end{array}$ & $<0.001$ & $\begin{array}{c}-0.52 \\
(-1.2-0.18)\end{array}$ & 0.145 \\
\hline & $\begin{array}{l}\text { Exekutiv } \\
\text { funktion }\end{array}$ & $--^{c}$ & --- & $\begin{array}{c}-0.45 \\
(-0.99-0.10)\end{array}$ & 0.108 & $\begin{array}{c}-0.77 \\
(-1.2-(-0.38))\end{array}$ & $<0.001$ & $\begin{array}{c}-0.74 \\
(-1.7-0.28)\end{array}$ & 0.149 \\
\hline $\begin{array}{c}\text { Sociala } \\
\text { funktioner }\end{array}$ & $\begin{array}{l}\text { Frekvens } \\
\text { ensamhet }\end{array}$ & $\begin{array}{c}0.14 \\
(-0.077- \\
0.35)\end{array}$ & 0.209 & $\begin{array}{c}0.21 \\
(-0.014-0.43)\end{array}$ & 0.066 & $\begin{array}{c}0.17 \\
(-0.061-0.41)\end{array}$ & 0.146 & $\begin{array}{c}0.11 \\
(-0.29-0.51)\end{array}$ & 0.586 \\
\hline \multirow[t]{2}{*}{$\begin{array}{c}\text { Psykiska } \\
\text { funktioner }\end{array}$} & $\begin{array}{l}\text { Depres- } \\
\text { sivitet, } \\
\text { GDS-15- } \\
\text { poäng }\end{array}$ & $-{ }^{c}$ & --- & $\begin{array}{c}0.59 \\
(0.027-1.1)\end{array}$ & 0.040 & $\begin{array}{c}0.62 \\
(0.15-1.1)\end{array}$ & 0.010 & $\begin{array}{c}0.86 \\
(-0.067-1.8)\end{array}$ & 0.069 \\
\hline & $\begin{array}{l}\text { SSD vs } \\
\text { ND }\end{array}$ & $--^{c}$ & --- & 0.19 & 0.665 & $10^{\mathrm{d}}$ & 0.001 & 1.7 & 0.197 \\
\hline
\end{tabular}


Anmärkningar: ${ }^{a}=$ Det var fler kvinnor och färre män bland dem som föll bort, vilket var en återkommande tendens $i$ alla mätvågor, även om detta var bara var en signifikant association mellan T0-T1. ${ }^{b}=$ Det var fler personer med särskilt boende, och färre med självständigt boende bland dem som föll bort. ${ }^{c}=$ Ingen jämförelse möjlig, eftersom den första mätvågen av denna variabel var vid T1. ${ }^{d}=$ Det var fler med SSD och färre med ND bland dem som föll bort. 


\section{Resultat}

\subsection{Studie 1: Normalt åldrande, SSD eller depression: en kvalitativ analys.}

Syftet för studie 1 var att undersöka upplevelser av tillvaron hos äldre äldre personer med SSD, och att göra en kvalitativ jämförelse med upplevelserna bland äldre äldre personer med syndromal depression respektive ND. Den kvalitativa analysen av de 27 intervjuerna (ND n=6; SSD $n=13$; syndromal depression $n=8$ ) genererade 4 teman som beskriver olika aspekter av tillvaron hos äldre-äldre personer med SSD (Tabell 4).

Tabell 4. Subteman och teman från den kvalitativa innehållsanalysen av intervjuer bland äldre äldre personer med SSD, ND och syndromal depression $(n=27)$.

\begin{tabular}{|l|c|}
\hline \multicolumn{1}{|c|}{ Subteman } & \multicolumn{1}{c|}{ Teman } \\
\hline Förlust av viktiga närstående personer & $\begin{array}{c}\text { Livskurvan och kroppen går } \\
\text { nedåt }\end{array}$ \\
\hline Kroppen försvagas & \\
\hline Livets slut, ålderdomen & Att hänga med i livet \\
\hline $\begin{array}{l}\text { Bibehålla vardagslivet } \\
\text { värderingar i livet } \\
\text { Meningsfullhet från deltagande }\end{array}$ & \\
\hline Ensamhet, känsla av exkludering, övergiven & \\
\hline Ett mer främmande samhälle & Ta en dag i taget \\
\hline Undvika ältande, leva i nuet & \\
\hline Kavla upp ärmarna, ta nya tag & Att klara sig själv \\
\hline Skifta perspektiv, jag har det bra trots allt & \\
\hline Självbestämmande & \\
\hline Att klara sig själv, oberoende & \\
\hline
\end{tabular}

Ett tema var upplevelsen att kroppsliga funktioner, (hörsel, syn, fysisk ork, rörlighet) och annat i livet går nedåt i livet under ålderdomen. Nedgången åtföljdes även av en ökande upplevelse av stelhet och smärta i kroppen, och konsekvent mer begränsade aktiviteter och social isolering, som förstärktes av att kontakten till jämnåriga vänner och släktingar efter hand förlorats genom antingen dödsfall eller demenssjukdom. Tankar på åldrandeprocesser och död var mindre stressande tankar, medan oron för ett växande socialt hjälpbehov eller en minskande autonomi var mer emotionellt laddade. 
"I: Ja. Tycker du att det här med att du blivit äldre, hur har det påverkat dig?

$R$ : Ja, det är någonting som liksom följer med livet, så att det är väl någonting som man allt eftersom finner sig $i$, tror jag. ... Ja, vad ska man göra då? Hoppa av? Det vill man ju inte.

I: Man finner sig...?

R: Ja visst. Det är ju inget annat att göra. Alderdomen kan man inte bromsa.” (Intervju 8)

Ett andra tema var önskan eller strävan att ändå hänga med i livet och samhället, vilket innebar att fortsätta vara aktiv, att vara involverad i vad som händer, och att vara en del av en större helhet, trots den fysiska nedgången. Istället för mer ansträngande aktiviteter som resande, promenader och trädgårdsarbete, så beskrev informanterna att de ägnade sig åt mer stillasittande aktiviteter som korsord, sudoku, TV, telefonsamtal till släktingar, ljudböcker och annat.

Ett tredje tema var att ta en dag i taget: den ofrånkomliga nedgången i fysiska funktioner, aktiviteter och social interaktion, tillsammans med andra motgångar i ålderdomen gjorde informanterna ibland ledsna. Trots dessa stunder av ledsenhet, så upplevde de att de hade ett bra liv som helhet, och de försökte att inte älta eller begrava sig i sådana motgångar, utan istället att ta saker som det kommer - en dag i taget, eller ett år i taget.

$R:$ Ja, jag tar ju en dag i taget... jag tittar inte fram eller har några idéer långt fram $i$ tiden, utan man tar en dag i taget och överlever man den så är det... (Intervju 23).

Att ta saker som det kommer var ett komplext uttryck med olika betydelser, i huvudsak relaterat till kognitiva copingstrategier. Det beskrevs bland annat som att leva i nuet och inte bekymra sig i förväg utan att låta framtiden vara oviss. I mötet med motgångar så var det en strategi att kämpa på och kavla upp ärmarna. I jämförelsen mellan den egna situationen och vännernas situationer, eller i jämförelsen med förväntningarna på ålderdomen, så uttryckte de äldre äldre personerna att livet hade varit bra trots allt.

Det sista och fjärde temat handlade om upplevelsen att klara sig själva och leva ett självständigt liv, trots den sviktande kroppen och det nedåtgående livet. Upplevelsen att klara sig själv var avgörande för den övergripande livskvaliteten, och paradoxalt nog tycktes denna upplevelse vara relativt oberoende av individens funktionsnivå eller hjälpbehov. Även när fysiska funktioner var begränsade och informanternas hjälpbehov var större, så framhöll de att de trivdes väl eftersom de fortfarande klarade sig relativt självständigt.

R: Det enda nu är ju att man inte behöver bli liggandes, sängliggande, och får det besvärligt på så vis.

I: $M m, m m$.

R: Det vill man ju inte, för det vill man ju inte. För jag menar, jag har ju levt så länge. Jag vill hellre avsluta mitt liv än att bli liggande på... och det tror jag de flesta äldre 
människor tänker. De vill hellre få avsluta sina liv än att ligga och vara andra till besvär och...... (Intervju 6)

Att klara sig själv kunde betyda att sköta hushållet, laga mat, klä sig eller bädda sängen själv, eller alternativt kunde det vara ett uttryck för självbestämmande och autonomi med en mer grundläggande önskan att få kontrollera sin egen tid och sina aktiviteter. Till exempel de som kunde gå var rädda att behöva sitta ned hela tiden, medan de som var sittande mycket var rädda för att bli sängliggande $\mathrm{i}$ framtiden.

Likheter mellan informanter i de olika kategorierna av depressivitet var långtgående, och samtliga fyra analysteman kunde återfinnas i respektive kategori med t ex likartade beskrivningar av nedgången av kroppen och livskurvan. Bland personer med syndromal depression jämfört med SSD var dock upplevelsen av kroppslig nedgång och dess konsekvenser mer framträdande, och i intervjuerna beskrevs hur livet var kraftigt begränsat antingen fysiskt, socialt eller bäggedera. Upplevelsen av självständighet framstod svagare bland personer med syndromal depression, och istället framhöll flera personer en önskan om utökade hjälpinsatser jämfört med den aktuella situationen. Beskrivningar av positiva känslor och meningsfulla aktiviteter var också generellt mer varierande och generellt mindre framträdande hos personer med depression jämfört med SSD, både i termer av känslointensitet och i sättet det uttrycktes. Ännu en skillnad var att personer med syndromal depression jämfört med SSD talade mindre om nuet och att ta en dag i taget, och istället mer om sorger och negativa minnen, liksom om oro för framtiden.

Mellan SSD och ND var likheterna ännu större (än mellan SSD och syndromal depression), och personer av bägge kategorier beskrev betydelsen av att klara sig själva och att ha eget självbestämmande, för att må bra. De beskrev under temat att ta en dag i taget om behovet att anpassa aktivitetsnivån till nya förutsättningar av kroppslig nedgång och förluster i ålderdomen, och copingstrategier för att möta motgångar var likartade mellan SSD och ND. Den tydligaste skillnaden mellan berättelser av personer med SSD jämfört med ND var att de med SSD beskrev intensiteten och omfattningen av lidande, smärta och kroppslig nedgång som lite större än vad de med ND beskrev. Exempelvis beskrev personer med SSD svår smärta som en ständig följeslagare, och uttalade hörselnedsättningar som begränsade hela tillvaron till någonting ganska litet, medan personer med ND uttryckte den kroppsliga nedgången genom uttryck som "det är bra, så länge man är någorlunda frisk". Sammanfattningsvis erhölls en rik beskrivning av upplevelser av tillvaron hos äldre äldre personer med SSD, och likheterna var stora mellan samtliga tre kategorier av depressivitet, även om skillnaderna föreföll lite större mellan SSD och syndromal depression än mellan SSD och ND.

\subsection{Resultat studie 2: markörer för SSD}

Syftet för den andra studien var att undersöka associerade faktorer till SSD bland äldre äldre personer, och att utveckla en modell för prediktion av SSD bland äldre äldre personer. De i förväg formulerade hypoteserna med motsvarande domäner hade operationaliserats genom 23 olika variabler (tabell 2 i metodkapitlet), och i de univariata binärlogistiska regressionerna visade 
sig visade sig 20 variabler vara signifikant relaterade till jämförelsen mellan SSD och ND (tabell 1 i manus 2 separat). Däremot var endast fyra variabler signifikant relaterade till jämförelsen mellan SSD och Depression. De 20 variabler som var signifikant associerade med kategoriseringen SSD-ND motsvarade samtliga av de fyra domänerna, varför samtliga uppställda nollhypoteser förkastades.

Vid de efterföljande multivariata binärlogistiska regressionerna var det sju variabler från samtliga fyra domäner, vilka var associerade med SSD-ND, medan endast två variabler var signifikant associerade med SSD-Depression (tabell 5). De sju variabler som var associerade med SSD-ND presenteras i det följande i fallande ordning av OR: lägre subjektiv hälsa (EQ-VAS), ej meningsfullt liv, problem med hygien, ingen kontakt med grannar, användning av lugnade medel, tidigare affektiv störning, och tidigare stroke. De två variabler som var signifikant associerade med SSD-Depression var ej meningsfullt liv, och högre aktuell oro/nedstämdhet enligt EQ-5D. 
Tabell 5. Multivariata binärlogistiska regressioner för SSD vs ND och Depr vs SSD, samt multivariata ordinallogistiska och linjära regressioner i studie $2(n=371)$.

\begin{tabular}{|c|c|c|c|c|c|c|c|c|c|}
\hline \multirow[b]{2}{*}{ Domän } & \multirow[b]{2}{*}{ Variabel } & \multicolumn{2}{|c|}{$\begin{array}{l}\text { Multivariat } \\
\text { Log Regr }{ }^{a} \text {, } \\
\text { sannolikhet } \\
\text { SSD vs ND }\end{array}$} & \multicolumn{2}{|c|}{$\begin{array}{l}\text { Multivariat } \\
\text { Log Regr } \\
\text { sannolikhet } \\
\text { Depr vs SSD }\end{array}$} & \multicolumn{2}{|c|}{$\begin{array}{l}\text { Ordinallog Regr } \\
\text { inklusive ND, SSD } \\
\text { och Depr }\end{array}$} & \multicolumn{2}{|c|}{$\begin{array}{l}\text { Linjär Regr }{ }^{d}, G D S- \\
\text { poäng som en } \\
\text { kontinuerlig funktion }\end{array}$} \\
\hline & & $\begin{array}{c}\text { OR } \\
(95 \% \mathrm{CI})\end{array}$ & $\mathbf{P}$ & $\begin{array}{c}\text { OR } \\
(95 \% \mathrm{CI})\end{array}$ & $\mathbf{P}$ & $\begin{array}{c}\text { OR } \\
(95 \% \mathrm{CI})\end{array}$ & $\mathbf{P}$ & $\begin{array}{l}\text { Ostandard- } \\
\text { iserat B } \\
(95 \% \mathrm{CI})\end{array}$ & $\mathbf{P}$ \\
\hline $\begin{array}{l}\text { Sociodemo- } \\
\text { grafiska } \\
\text { faktorer }\end{array}$ & $\begin{array}{l}\text { Ingen } \\
\text { kontakt med } \\
\text { grannar }\end{array}$ & $\begin{array}{c}4.0 \\
(1.6-10)\end{array}$ & 0.003 & & ns & $\begin{array}{c}3.8 \\
(1.7-8.2)\end{array}$ & 0.001 & $\begin{array}{c}0.91 \\
(0.41-1.4)\end{array}$ & $<0.001$ \\
\hline \multirow[t]{2}{*}{$\begin{array}{l}\text { Avtagande } \\
\text { fysiska } \\
\text { funktioner }\end{array}$} & $\begin{array}{l}\text { Huvud- } \\
\text { sakliga } \\
\text { aktiviteter } \\
\text { (EQ-5D), } \\
\text { vissa eller } \\
\text { svåra } \\
\text { problem }\end{array}$ & & ns & & ns & $\begin{array}{c}3.5 \\
(1.9-6.6)\end{array}$ & $<0.001$ & $\begin{array}{c}1.0 \\
(0.60-1.4)\end{array}$ & $<0.001$ \\
\hline & $\begin{array}{l}\text { Hygien (EQ- } \\
\text { 5D), vissa } \\
\text { eller svåra } \\
\text { problem }\end{array}$ & $\begin{array}{c}5.5 \\
(2.1-14)\end{array}$ & 0.001 & & ns & & ns & & $\mathrm{ns}$ \\
\hline \multirow[t]{4}{*}{$\begin{array}{l}\text { Neuropsy- } \\
\text { kiatriska } \\
\text { faktorer }\end{array}$} & $\begin{array}{l}\text { Tidigare } \\
\text { affektiv } \\
\text { sjukdom }\end{array}$ & $\begin{array}{c}3.5 \\
(1.3-9.4)\end{array}$ & 0.015 & & ns & & ns & & ns \\
\hline & $\begin{array}{l}\text { Aktuell oro } \\
\text { /nedstämd- } \\
\text { het (EQ-5D), } \\
\text { måttlig eller } \\
\text { svår }\end{array}$ & & ns & $\begin{array}{c}6.9 \\
(1.5-32)\end{array}$ & 0.014 & & $\mathrm{~ns}$ & & $\mathrm{~ns}$ \\
\hline & $\begin{array}{l}\text { Användning } \\
\text { av lugnande } \\
\text { läkemedel }\end{array}$ & $\begin{array}{c}3.9 \\
(1.1-14)\end{array}$ & 0.037 & & ns & $\begin{array}{c}3.6 \\
(1.5-9.0)\end{array}$ & 0.006 & $\begin{array}{c}1.1 \\
(0.45-1.7)\end{array}$ & 0.001 \\
\hline & $\begin{array}{l}\text { Tidigare } \\
\text { stroke }\end{array}$ & $\begin{array}{c}2.9 \\
(1.2-7.1)\end{array}$ & 0.022 & & ns & $\begin{array}{c}2.4 \\
(1.1-5.2)\end{array}$ & 0.021 & $\begin{array}{c}0.90 \\
(0.42-1.4)\end{array}$ & $<0.001$ \\
\hline \multirow[t]{3}{*}{$\begin{array}{l}\text { Existentiella } \\
\text { faktorer }\end{array}$} & $\begin{array}{l}\text { Oro för } \\
\text { framtiden, } \\
\text { ibland eller } \\
\text { ofta }\end{array}$ & & ns & & ns & $\begin{array}{c}2.3 \\
(1.3-4.3)\end{array}$ & 0.006 & $\begin{array}{c}0.60 \\
(0.26-0.94)\end{array}$ & 0.001 \\
\hline & $\begin{array}{l}\text { Lägre } \\
\text { subjektiv } \\
\text { hälsa (EQ } \\
\text { VAS <70) }\end{array}$ & $\begin{array}{c}6.9 \\
(3.5-13)\end{array}$ & $<0.001$ & & ns & $\begin{array}{c}5.1 \\
(2.7-9.6)\end{array}$ & $<0.001$ & $\begin{array}{c}0.79 \\
(0.43-1.2)\end{array}$ & $<0.001$ \\
\hline & $\begin{array}{l}\mathrm{Ej} \\
\text { meningsfullt } \\
\text { liv }\end{array}$ & $\begin{array}{c}5.9 \\
(2.4-14)\end{array}$ & $<0.001$ & $\begin{array}{c}3.8 \\
(1.3-11)\end{array}$ & 0.015 & $\begin{array}{c}5.9 \\
(2.9-12)\end{array}$ & $<0.001$ & $\begin{array}{c}1.6 \\
(1.1-2.0)\end{array}$ & $<0.001$ \\
\hline
\end{tabular}


Anmärkningar: ${ }^{a}=$ Nagelkerke $R^{2}=0.464 ;{ }^{b}=$ Nagelkerke $R^{2}=0.246 ;{ }^{c}=$ Nagelkerke Pseudo- $R^{2}=$ 0.506 , test av parallella linjer $p=0,842$, vilket indikerar att en ordinallogistisk modell är passande i förhållande till data ${ }^{d}=$ korrigerat $R^{2}=0.478$.

Vid efterföljande ordinallogistisk respektive linjär multivariat regression, så var det istället sju delvis andra faktorer som var signifikant associerade med de beroende variablerna ND-SSDdepression respektive GDS-15-poäng (motsvarande graden av depressivitet), i det följande beskrivet i fallande ordning av OR: ej meningsfullt liv, lägre subjektiv hälsa, ingen kontakt med grannar, användning av lugnande läkemedel, problem med huvudsakliga aktiviteter, tidigare stroke, oro för framtiden.

Ett detaljfynd i sammanhanget var att variablerna problem med hygien, tidigare affektiv sjukdom liksom aktuell grad av oro/nedstämdhet enligt EQ-5D föll ut signifikant i binärlogistiska men inte i ordinallogistisk eller linjär regression, medan problem med huvudsakliga aktiviteter (EQ-5D) och oro för framtiden föll ut i ordinallogistisk och linjär regression, men inte i föregående binärlogistiska regressioner.

Analyser av skillnader mellan GDS-svarande ( $n=371)$ och icke-svarande $(n=125)$ av de $n=496$ som ifyllt enkäten vid baseline visade systematiska skillnader, då icke-svarande oftare var kvinnor, hade särskilt boende, och mer problem med rörlighet, vardagsaktiviteter, hygien och subjektiv hälsa. GDS-svarande hade å andra sidan mer synnedsättning, tidigare genomgången stroke, liksom hjärtsvikt eller hjärtinfarkt, varför det inte helt systematiskt var mer multisjukdom bland icke-svarande.

\subsection{Resultat studie 3: direkta kostnader för personer med SSD}

Syftet med studie 3 var att jämföra prospektiva direkta kostnader för hälso- och sjukvård respektive omsorg, och sjukvårdskonsumtion för personer med SSD jämfört ND i en population av äldre äldre personer, under en femårsperiod. Ett andra syfte var att utveckla en modell för att predicera direkta sjukvårdskostnader bland äldre äldre personer med SSD. På basen av tidigare litteratur om yngre åldrar hade vi hypoteser att direkta kostnader skulle vara a) högre för äldre äldre personer med SSD jämfört med ND, oberoende av somatisk multisjukdom, och att b) faktorerna somatisk multisjukdom, nedsatt kognitiv funktion [133], nedsatt fysisk funktion och ADL-förmåga [134], kronisk smärta [135], och ensamhet [136] också skulle predicera ökade direkta kostnader.

Analyser byggde på de reviderade kategorierna för depressivitet i studie 3, nämligen ND Both, SSD Ever och Depr Ever, vilket motsvarade $n=316$ individer (ND Both $n=152$; SSD Ever $n=128$; Depr Ever n=36).

Resultat var att den totala direkta genomsnittskostnaden för sjukvård per månad var €608 $( \pm 628)$ per invånare, vilket extrapolerat till årlig kostnad motsvarar €7301 ( $(7539)$ (tabell 6). Slutenvård stod för nästan hälften av kostnaderna, medan primärvård och sekundärvård motsvarade liknande proportioner av resten. 
Tabell 6. Jämförelse av prospektiva direkta sjukvårdskostnader och sjukvårdskonsumtion mellan kategorierna ND Both, SSD Ever and Depr Ever med Mann-Whitney U-tester.

\begin{tabular}{|c|c|c|c|c|c|c|c|c|}
\hline & & & $\begin{array}{l}\text { NDBoth } \\
(n=152)\end{array}$ & $\begin{array}{c}\text { SSD } \\
\text { Ever } \\
(\mathbf{n}=\mathbf{1 2 8})\end{array}$ & $\begin{array}{l}\text { Depr } \\
\text { Ever } \\
(\mathrm{n}=36)\end{array}$ & $\begin{array}{c}\text { Samt- } \\
\text { liga } \\
(\mathrm{n}=316)\end{array}$ & $\begin{array}{c}\text { p-värde } \\
\text { (U- } \\
\text { test), }{ }^{\text {a, b }} \\
\text { SSD } \\
\text { Ever vs } \\
\text { ND } \\
\text { Both }\end{array}$ & $\begin{array}{c}\text { p-värde } \\
\text { (U- } \\
\text { test), } \\
\text { Depr } \\
\text { Ever vs } \\
\text { ND } \\
\text { Both }\end{array}$ \\
\hline \multirow{7}{*}{$\begin{array}{c}\text { Direkta } \\
\text { sjukvårds- } \\
\text { kostnader } \\
\text { per capita } \\
\text { och månad } \\
(€)^{\mathbf{c}}\end{array}$} & $\begin{array}{c}\text { Total } \\
\text { sjukvårds- } \\
\text { kostnad, } \\
\text { medel (SD) }\end{array}$ & & $436(367)^{d}$ & $\begin{array}{c}634 \\
(611)^{d}\end{array}$ & $\begin{array}{c}693 \\
(759)\end{array}$ & $\begin{array}{c}545 \\
(539)^{\mathrm{e}}\end{array}$ & 0.048 & 0.018 \\
\hline & $\begin{array}{l}\text { Slutenvård, } \\
\text { medel (SD) }\end{array}$ & & $171(234)$ & $\begin{array}{c}290 \\
(396)\end{array}$ & $\begin{array}{c}280 \\
(336)\end{array}$ & $\begin{array}{l}224 \\
(319)^{\mathrm{f}}\end{array}$ & 0.014 & 0.068 \\
\hline & Öppenvård & $\begin{array}{l}\text { Primär- } \\
\text { vård, } \\
\text { medel } \\
\text { (SD) }\end{array}$ & $148(104)$ & $\begin{array}{c}197 \\
(189)\end{array}$ & $\begin{array}{c}348 \\
(591)\end{array}$ & $\begin{array}{c}184 \\
(239)^{\mathrm{f}}\end{array}$ & 0.005 & 0.003 \\
\hline & & $\begin{array}{l}\text { Sekundär } \\
\text { öppenvård } \\
\text {, medel } \\
\text { (SD) }\end{array}$ & $141(220)$ & $\begin{array}{c}149 \\
(206)\end{array}$ & $106(81)$ & $\begin{array}{c}136 \\
(196)^{f}\end{array}$ & 0.311 & 0.707 \\
\hline & $\begin{array}{l}\text { Läkemedel, } \\
\text { g medel } \\
\text { (SD) }\end{array}$ & & 67 (107) & $82(69)$ & $83(51)$ & $77(90)$ & 0.005 & 0.113 \\
\hline & $\begin{array}{c}\text { Icke- } \\
\text { farmako- } \\
\text { logiska } \\
\text { kompo- } \\
\text { nenter, } \\
\text { medel (SD) }\end{array}$ & & $343(330)$ & $\begin{array}{c}516 \\
(543)\end{array}$ & $\begin{array}{c}525 \\
(449)\end{array}$ & $\begin{array}{c}446 \\
(467)\end{array}$ & 0.005 & 0.013 \\
\hline & $\begin{array}{c}\text { Privat } \\
\text { sjukvård, } \\
\text { medel (SD) }\end{array}$ & & 49 (77) & $40(90)$ & $\begin{array}{c}126 \\
(571)\end{array}$ & $56(208)$ & 0.048 & 0.675 \\
\hline \multirow{2}{*}{$\begin{array}{l}\text { Kommu- } \\
\text { nala } \\
\text { direkta } \\
\text { kostnader } \\
\text { per capita } \\
\text { och månad } \\
(€)^{i}\end{array}$} & $\begin{array}{c}\text { Totala } \\
\text { kostnader, } \\
\text { medel (SD) }\end{array}$ & & $\begin{array}{c}402 \\
(1078)\end{array}$ & $\begin{array}{c}975 \\
(1398)\end{array}$ & $\begin{array}{c}2298 \\
(1593)\end{array}$ & $\begin{array}{c}820 \\
(1411)\end{array}$ & 0.005 & 0.003 \\
\hline & $\begin{array}{c}\text { Särskilt } \\
\text { boende }{ }^{\mathrm{j}} \\
\text { medel (SD) }\end{array}$ & & 37 (166) & $\begin{array}{l}109 \\
(248)\end{array}$ & $\begin{array}{c}225 \\
(277)\end{array}$ & $90(246)$ & 0.005 & 0.003 \\
\hline
\end{tabular}


Forts. Tabell 6.

\begin{tabular}{|c|c|c|c|c|c|c|c|c|}
\hline & & & $\begin{array}{l}\text { NDBoth } \\
(n=152)\end{array}$ & $\begin{array}{c}\text { SSDEver } \\
(\mathrm{n}=128)\end{array}$ & $\begin{array}{c}\text { DeprEver } \\
(\mathrm{n}=36)\end{array}$ & $\begin{array}{c}\text { Samtliga } \\
(\mathrm{n}=316)\end{array}$ & $\begin{array}{c}\text { p- } \\
\text { värde } \\
\text { (U- } \\
\text { test), } \\
\text { be } \\
\text { SSD } \\
\text { Ever } \\
\text { vs ND } \\
\text { Both }\end{array}$ & $\begin{array}{c}\text { p- } \\
\text { värde } \\
\text { (U- } \\
\text { test), } \\
\text { bo, } \\
\text { Depr } \\
\text { Ever } \\
\text { vs ND } \\
\text { Both } \\
\end{array}$ \\
\hline \multirow{8}{*}{$\begin{array}{l}\text { Sjukvårds- } \\
\text { konsum } \\
\text { tion per } \\
\text { capita och } \\
\text { månad }\end{array}$} & $\begin{array}{l}\text { Totalt antal } \\
\text { sjukvårds- } \\
\text { besök, } \\
\text { medel (SD) }\end{array}$ & & $1.6(1.5)$ & $1.8(3.1)$ & $2.8(7.4)$ & $1,8(3,3)^{\mathrm{K}}$ & 0.620 & 0.469 \\
\hline & $\begin{array}{l}\text { Antal besök } \\
\text { till läkare } \\
\text { totalt, }{ }^{1} \\
\text { medel (SD) }\end{array}$ & & $\begin{array}{c}0.50 \\
(0.38)\end{array}$ & $\begin{array}{c}0.48 \\
(0.56)\end{array}$ & $0.74(2.2)$ & $\begin{array}{c}0.52 \\
(0.87)\end{array}$ & 0.240 & 0.364 \\
\hline & \multirow[t]{2}{*}{ Slutenvård } & $\begin{array}{c}\text { Antal } \\
\text { slutenvårds- } \\
\text { tillfällen; } \\
\text { medel (SD) }\end{array}$ & $\begin{array}{c}1.9 * 10^{-2} \\
\left(3.6 * 10^{-2}\right)\end{array}$ & $\begin{array}{c}1.4 * 10^{-2} \\
\left(3.8 * 10^{-2}\right)\end{array}$ & $\begin{array}{c}2.3 * 10^{-2} \\
\left(6.4 * 10^{-2}\right)\end{array}$ & $\begin{array}{c}1.7 * 10^{-2} \\
\left(4.0 * 10^{-2}\right)\end{array}$ & 0.104 & 0.626 \\
\hline & & $\begin{array}{c}\text { Specifik } \\
\text { psykiatrisk } \\
\text { slutenvård, } \\
\text { antal } \\
\text { tillfällen; }^{\text {m }} \\
\text { medel (SD) }\end{array}$ & $\begin{array}{c}1.0^{*} * 10^{-4} \\
\left(1.4 * 10^{-3}\right)\end{array}$ & $\begin{array}{c}0.00 \\
(0.00)\end{array}$ & $0.00(0.0)$ & $\begin{array}{c}1.0^{*} * 10^{-4} \\
\left(9.4 * 10^{-4}\right)\end{array}$ & 0.620 & 0.626 \\
\hline & \multirow[t]{4}{*}{ Öppenvård } & $\begin{array}{l}\text { Primärvård, } \\
\text { antal besök; } \\
\text { medel(SD) }\end{array}$ & $1.3(1.3)$ & $1.5(3.0)$ & $2.6(7.3)$ & $1.5(3.2)$ & 0.670 & 0.626 \\
\hline & & $\begin{array}{c}\text { Akut- } \\
\text { mottagning- } \\
\text { en, antal } \\
\text { besök; }{ }^{\mathrm{n}} \\
\text { medel (SD) }\end{array}$ & $\begin{array}{c}3.9 * 10^{-2} \\
\left(4.6 * 10^{-2}\right)\end{array}$ & $\begin{array}{c}4.8 * 10^{-2} \\
\left(7.0^{*} 10^{-2}\right)\end{array}$ & $\begin{array}{c}3.5^{*} 10^{-2} \\
\left(4.5 * 10^{-2}\right)\end{array}$ & $\begin{array}{c}4.2 * 10^{-2} \\
\left(5.7 * 10^{-2}\right)\end{array}$ & 0.690 & 0.626 \\
\hline & & $\begin{array}{c}\text { All } \\
\text { sekundär } \\
\text { öppenvård, } \\
\text { antal besök; } \\
\text { medel (SD) }\end{array}$ & $\begin{array}{c}0.31 \\
(0.37)\end{array}$ & $\begin{array}{c}0.30 \\
(0.71)\end{array}$ & $\begin{array}{c}0.15 \\
(0.17)\end{array}$ & $\begin{array}{c}0.28 \\
(0.53)\end{array}$ & 0.104 & 0.008 \\
\hline & & $\begin{array}{c}\text { Specifik } \\
\text { psykiatrisk } \\
\text { öppenvård, } \\
\text { antal } \\
\text { besök; }{ }^{\mathrm{m}} \\
\text { medel (SD) }\end{array}$ & $\begin{array}{c}1.0^{*} 10^{-2} \\
\left(1.2 * 10^{-2}\right)\end{array}$ & $\begin{array}{c}1.6 * 10^{-3} \\
\left(1.6 * 10^{-2}\right)\end{array}$ & $\begin{array}{c}0.00 \\
(0.00)\end{array}$ & $\begin{array}{c}1.7 * 10^{-2} \\
\left(2.2 * 10^{-2}\right)\end{array}$ & 0.620 & 0.626 \\
\hline
\end{tabular}

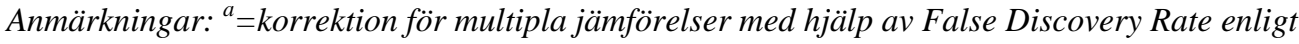
Benjamini och Hochberg (1) via kalkylator online på hemsidan för SDM projektet 
(https://www.sdmproject.com/utilities/?show=FDR; den 23e januari 2018; Neuroimaging software library). Dessa beräkningar gjordes separat för kostnader och sjukvårdskonsumtion. ${ }^{b}=$ frihetsgrader (df) för Mann-Whitney U-tester var samma som minsta gruppstorlek $i$ varje jämförelse, d.v.s. 128 frihetsgrader ( $n=128$ för SSD Ever) i jämförelsen mellan SSD Ever och ND Both, och 36 frihetsgrader ( $n=36$ för Depr Ever) i jämförelsen mellan Depr Ever och ND Both. ${ }^{c}=$ korrigerat för antal månader av överlevnad. ${ }^{d}=k_{\text {voten }}$ mellan medelvärdena SSD Ever $/ N D$ Both var 1.45, medan motsvarande kvot mellan medianer var 1.48. Median total sjukvårdskostnad var $€ 433$ (q1=211, q3=842) för SSD Ever och $€ 293$ (q1=190, q3=579) för ND Both. Sensitivitetsanalyser med varierande diskonteringsgrader förändrade inte kvoten mellan medelvärdena. ${ }^{e}=$ genomsnittlig total sjukvårdskostnad var $€ 608$ ( \pm 628$)$ för hela urvalet $n=371$, och $€ 545( \pm 539)$ för det mindre urvalet $n=316$. Median total sjukvårdskostnad för hela urvalet $n=371$ var $€ 412$ ( $q 1=216, q 3=781)$, jämfört med medianen $€ 371$ ( $q 1=201, q 3=718)$ för urvalet $n=316$. I känslighetsanalyser var medelvärdet för hela urvalet $(n=371) € 645( \pm 666)$ vid $0 \%$

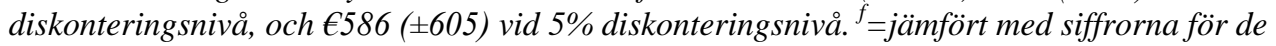
$n=316$ i tabellen, så var motsvarande medelkostnader för hela urvalet $(n=371) € 267( \pm 381)$ för slutenvård, $€ 191$ ( \pm 250$)$ för primärvård och $€ 149$ (+230) för sekundär öppenvård. ${ }^{g}=$ dessa siffror byggde bara på offentliga kostnadsdata. ${ }^{h}=$ Endast $n=160$ hade någon privat sjukvårdskonsumtion under studieperioden. ${ }^{i}=$ Kommunala kostnader byggde bara på data från en ettårsperiod mellan 2011-12, och det var $n=242$ som fortfarande levde vid tiden, varav $n=134$ med ND Both, $n=82$ med SSD Ever och $n=26$ med Depr Ever. ${ }^{j}=$ Endast 16\% (38/242) av individerna med kommunala kostnader levde i särskilt boende. ${ }^{k}=$ Medelantalet sjukvårdsbesök var 1.8 ( \pm 3.2$)$ för hela urvalet $n=371$, och 1.8 ( \pm 3.3 ) för det mindre urvalet $n=316$. Medianen för totala antalet sjukvårdsbesök var $1.0(q 1=0.42, q 3=2.1)$ för hela urvalet $n=371$, jämfört med 1.2 $(q 1=0.52, q 3=2.3)$ för det mindre urvalet $n=316 .^{l}=$ Antal besök till läkare baserades bara $p a ̊$ data från fyra år av studieperioden. ${ }^{m}=$ Det var bara 1 psykiatriskt slutenvårdstillfälle, och bara 31 specialistpsykiatriska öppenvårdsbesök av det totala antalet 28626 besök för dessa 371 personer under den femåriga studieperioden. ${ }^{n}=$ besök på akutmottagningen var endast till läkare.

Den privata sjukvården stod för bara $10 \%$ av sjukvårdskostnaderna under den aktuella tidsperioden. Trots att bara ca $16 \%$ av urvalet hade särskilt boende (som en avgörande kostnadskomponent för kommunala kostnader), så var de kommunala totalkostnaderna väsentligt högre än sjukvårdskostnaderna per månad av överlevnad. En generellt positivt skev distribution av sjukvårdskostnader i urvalet motsvarade det faktum att ett mindre antal individer hade uttalat höga kostnader (individer med extremt höga vårdkostnader motsvarade i huvudsak personer med multisjukdom), medan ett större antal individer hade kostnader långt under genomsnittet.

Jämförelserna mellan kategorierna av depressivitet visade att personer med SSD Ever hade 45\% högre genomsnittskostnad (€634 jämfört med €436) för sjukvård per månad av överlevnad jämfört med ND Both, vilket var en signifikant skillnad enligt u-testerna. Sådan skillnad mellan grupperna var signifikant även för de båda komponenterna slutenvård och primärvård, men däremot inte vad gäller specialiserad öppenvård. Även de kommunala genomsnittskostnaderna per månad var signifikant högre för personer med SSD Ever (€975) jämfört med ND Both (€402). Trots signifikant skilda genomsnittskostnader så var däremot inte sjukvårdskonsumtionen, mätt som antal sjukvårdskontakter eller besök och slutenvårdstillfällen, 
signifikant åtskild mellan SSD Ever och ND Both. Även personer med Depr Ever hade högre genomsnittliga totalkostnader för sjukvård och kommunal omsorg jämfört med ND Both, även om flertalet kostnadskomponenter inte skiljde sig signifikant mellan dessa grupper.

I efterföljande multivariat linjär regression med logaritmerade värden av totala sjukvårdskostnaden som beroende variabel visade sig fem oberoende variabler, som prediktionsmodell från baslinjemätningen, signifikant kunna förutsäga sjukvårdskostnad per månad över fem år framöver - här presenterade i ordningsföljd: manligt kön, mer frekvent upplevelse av ensamhet, förekomst av SSD jämfört med ND, grad av ADL-funktion och somatisk multisjukdom (tabell 7). Effektstorlekar av dessa prediktorer var emellertid små, vilket talar för att andra faktorer kan vara mer avgörande än dessa för att förklara storleken av sjukvårdskostnader för äldre äldre personer.

Tabell 7. Univariata och multivariata linjära regressioner med logaritmen av totala sjukvårdskostnader per månad överlevnad som beroende variabel.

\begin{tabular}{|c|c|c|c|c|}
\hline \multirow[b]{2}{*}{ Oberoende prediktorvariabel } & \multicolumn{2}{|c|}{$\begin{array}{l}\text { Univariat regression, Log } \\
\text { sjukvårdskostnad }\end{array}$} & \multicolumn{2}{|c|}{$\begin{array}{l}\text { Multivariat regression }{ }^{\text {a, b }}, \text { Log } \\
\text { sjukvårdskostnad }\end{array}$} \\
\hline & $\begin{array}{c}\text { Koefficient } \\
(95 \% \mathrm{CI})\end{array}$ & $\begin{array}{l}\text { t; df; p- } \\
\text { värde; }\end{array}$ & $\begin{array}{c}\text { Koefficient } \\
(95 \% \mathrm{CI})\end{array}$ & t; df; p-värde \\
\hline Manligt kön (ja/nej) & $\begin{array}{c}0.08 \\
(-0.02-0.18)\end{array}$ & $\begin{array}{c}1.65 ; 353 ; \\
0.100\end{array}$ & $\begin{array}{c}0.16 \\
(0.06-0.25)\end{array}$ & $\begin{array}{c}3.25 ; 264 \\
\text { 0.001 }^{\text {c }}\end{array}$ \\
\hline $\begin{array}{l}\text { Låg utbildningsnivå, <9 år } \\
\text { (ja/nej) }\end{array}$ & $\begin{array}{c}-0.064 \\
(-0.16-0.04)\end{array}$ & $\begin{array}{l}1.25 ; 347 \\
0.211\end{array}$ & $\begin{array}{c}-0.04 \\
(-0.14-0.05)\end{array}$ & $\begin{array}{c}0.89 ; 260 \\
0.374^{\mathrm{d}}\end{array}$ \\
\hline $\begin{array}{l}\text { Ensamhet, ibland eller ofta } \\
(\mathbf{j a} / \mathbf{n e j})\end{array}$ & $\begin{array}{c}0.11 \\
(0.02-0.20)\end{array}$ & $\begin{array}{l}2.37 ; 338 ; \\
\quad 0.018\end{array}$ & $\begin{array}{c}0.14 \\
(0.03-0.24)\end{array}$ & $\begin{array}{l}2.62 ; 264 ; \\
\quad 0.009\end{array}$ \\
\hline $\begin{array}{l}\text { Användning av förflyttnings- } \\
\text { hjälpmedel (ja/nej) }\end{array}$ & $\begin{array}{c}0.08 \\
(-0.02-0.17)\end{array}$ & $\begin{array}{c}1.57 ; 353 \\
0.118\end{array}$ & $\begin{array}{c}0.03 \\
(-0.08-0.14)\end{array}$ & $\begin{array}{c}0.52 ; 260 \\
0.604^{d}\end{array}$ \\
\hline $\begin{array}{l}\text { Lägre ADL-funktion (EQ-5D), } \\
\text { (ja/nej) }\end{array}$ & $\begin{array}{c}0.04 \\
(-0.08-0.15)\end{array}$ & $\begin{array}{l}0.61 ; 353 ; \\
\quad 0.541\end{array}$ & $\begin{array}{c}-0.15 \\
(-0.28-(-0.02)\end{array}$ & $\begin{array}{l}-2.27 ; 264 \\
\quad \mathbf{0 . 0 2 4}\end{array}$ \\
\hline $\begin{array}{l}\text { Smärtor/besvär (EQ-5D), } \\
\text { måttliga eller svåra (ja/nej) }\end{array}$ & $\begin{array}{c}0.00 \\
(-0.10-0.10)\end{array}$ & $\begin{array}{c}0.05 ; 353 ; \\
0.964\end{array}$ & $\begin{array}{c}0.02 \\
(-0.08-0.12)\end{array}$ & $\begin{array}{c}0.36 ; 260 \\
0.718^{d}\end{array}$ \\
\hline $\begin{array}{l}\text { Kognitiv dysfunktion } \\
\text { (MMSE<25p, ja/nej) }\end{array}$ & $\begin{array}{c}0.03 \\
(-0.11-0.16)\end{array}$ & $\begin{array}{l}0.40 ; 353 \\
0.687\end{array}$ & $\begin{array}{c}-0.06 \\
(-0.21-0.08)\end{array}$ & $\begin{array}{l}-0.85 ; 260 \\
0.394^{\mathrm{d}}\end{array}$ \\
\hline $\begin{array}{l}\text { Somatisk multisjukdom (n } \\
\text { kroniska sjukdomar) }\end{array}$ & $\begin{array}{c}0.05 \\
(0.01-0.08)\end{array}$ & $\begin{array}{l}2.88 ; 353 ; \\
\quad 0.004\end{array}$ & $\begin{array}{c}0.04 \\
(0.01-0.08)\end{array}$ & $\begin{array}{l}2.81 ; 264 \\
\quad 0.005\end{array}$ \\
\hline $\begin{array}{l}\text { Förekomst av SSD Ever vs ND } \\
\text { Both }\end{array}$ & $\begin{array}{c}0.13 \\
(0.03-0.23)\end{array}$ & $\begin{array}{l}2.58 ; 278 ; \\
\quad 0.011\end{array}$ & $\begin{array}{c}0.11 \\
(0.01-0.21)\end{array}$ & $\begin{array}{c}2.20 ; 264 \\
\mathbf{0 . 0 2 9}^{e}\end{array}$ \\
\hline
\end{tabular}

Anmärkningar: ${ }^{a}=$ Korrigerat $R^{2}=0.083$ för den stegvisa linjära regressionen, och $F=5.88$, $d f=5,264$ för modellen med de fem signifikanta prediktorerna kvinnligt kön, ensamhet, 
huvudsakliga aktiviteter, somatisk multisjukdom och förekomst av SSD. ${ }^{b}=$ De multivariata regressionerna baserades på $n=280$ av urvalet $n=316$, eftersom alla utom kategorierna ND Both $(n=152)$ och SSD Ever $(n=128)$ exkluderades listvis. ${ }^{c}=$ Genomsnittlig totalkostnad per månad överlevnad var $€ 611$ ( \pm 593$)$ för män, och $€ 500$ ( \pm 495$)$ för kvinnor, vilket innebar en $19 \%$ skillnad. ${ }^{d}=$ Koefficienten, $95 \%$ CI, och associerat p-värde för den multivariata regressionen är från den första stegvisa modellen, motsvarande en entry-procedur med alla variabler tillsammans. I den slutliga stegvis (baklänges automatiskt) framtagna regressionsmodellen var denna variabel $i$ själva verket avlägsnad eftersom den var icke-signifikant. ${ }^{e}=I$ sensitivitetsanalyserna var p-värdet för denna variabel 0.042 vid en diskonteringsgrad på $0 \%$, och 0.029 vid en diskonteringsgrad på $5 \%$.

\subsection{Resultat delstudie 4: morbiditet och mortalitet hos personer med SSD}

Syftet med studie 4 var att undersöka longitudinella utfall av SSD hos äldre äldre personer. På basen av tidigare litteratur uppställdes hypoteser att SSD jämfört med ND skulle vara associerat med lägre ADL-funktion [137], lägre subjektiv hälsa [138], lägre kognitiva funktioner [36], en högre grad av ensamhet [139], depressivitet [35], och högre dödlighet [23].

I överlevnadsanalyserna gjordes beräkningar utifrån mätningar av depressivitet vid baslinjen, medan vi för morbiditetsanalyser använde oss av depressivitets-mätningar från samtliga fyra mätvågor (vid 85, 86, 90 och 93 års ålder) under åtta års tid. Fokus för analyserna var att skilja effekter av SSD från ND, varför kategorin depression uteslöts från beräkningarna, och detta innebar att analyserna av sjuklighet byggde på urvalet $n=348$ (d.v.s. exklusive de $n=23$ personer som hade depression av samtliga $n=371$ GDS-svarande vid baslinjemätningen), även om samtliga $\mathrm{n}=371$ individer inkluderades för de följande analyserna av dödlighet.

Pga bl a dödsfall, sjukdom och trötthet så minskade deltagarfrekvensen vid varje mätvåg väsentligt vilket är vanligt vid longitudinella studier av äldre äldre personer, och separata bortfallsanalyser (tabell 3) visade att bortfallet var signifikant associerat med kvinnligt kön, särskilt boende, lägre ADL-förmåga, lägre global kognitiv förmåga (MMSE-poäng), högre grad av depressivitet (GDS-poäng), mm, av relevans för tolkningen av de övriga resultaten.

Morbiditetsanalyserna med LMM-metod visade att SSD jämfört med ND var associerat till en ökad sjuklighet i enlighet med flertalet hypoteser, och t ex motsvarade förekomsten av SSD en sänkning av I-ADL-poäng med i genomsnitt 23\% (5.4 av variationsvidden 24p) oavsett vilken mätvåg, även när man hade korrigerat för potentiella störfaktorer (tabell 8). 
Tabell 8. Effekt av SSD och tid på olika utfallsvariabler över fyra mätvågor och åtta år, i enlighet med beräkningar med metoden $\mathrm{LMM}^{\mathrm{a}}$, $\mathrm{n}=348$.

\begin{tabular}{|c|c|c|c|c|c|c|c|}
\hline \multirow{2}{*}{\multicolumn{2}{|c|}{$\begin{array}{c}\text { Utfallsvariabler med } \\
\text { longitudinella } \\
\text { mätningar }\end{array}$}} & \multicolumn{2}{|c|}{$\begin{array}{c}\text { Effekt av SSD vs ND, } \\
\text { okorrigerat }\end{array}$} & \multicolumn{2}{|c|}{$\begin{array}{c}\text { Effekt av SSD vs ND, } \\
\text { korrigerade värden }^{\text {b }}\end{array}$} & \multicolumn{2}{|c|}{ Effekt av tid ${ }^{\mathrm{b}, \mathrm{c}}$} \\
\hline & & \multirow{2}{*}{$\begin{array}{c}\begin{array}{c}\text { Parameter- } \\
\text { estimat } \\
\text { (CI) }\end{array} \\
-0.62 \\
(-0.80- \\
(-0.44)\end{array}$} & \multirow{2}{*}{$\begin{array}{c}\begin{array}{c}\mathrm{p}- \\
\text { värde }\end{array} \\
<0.001\end{array}$} & \multirow{2}{*}{$\begin{array}{c}\begin{array}{c}\text { Parameter- } \\
\text { estimat } \\
\text { (CI) }\end{array} \\
-0.58 \\
(-0.76- \\
(-0.40))\end{array}$} & \multirow{2}{*}{$\begin{array}{c}\text { p- } \\
\text { värde }\end{array}$} & \multirow{2}{*}{$\begin{array}{c}\begin{array}{c}\text { Parameter- } \\
\text { estimat }\end{array} \\
\text { T1-T4: }-0.56 \\
(-1.1-(-0.050))\end{array}$} & \multirow{2}{*}{$\begin{array}{c}\text { p-värde } \\
0.032\end{array}$} \\
\hline $\begin{array}{l}\text { Funk- } \\
\text { tionella } \\
\text { förmågor }\end{array}$ & P-ADL & & & & & & \\
\hline & I-ADL & $\begin{array}{l}-6.1 \\
(-7.1- \\
(-5.1)\end{array}$ & $<0.001$ & $\begin{array}{c}-5.4 \\
(-6.4-(-4.4))\end{array}$ & $<0.001$ & $\begin{array}{l}\text { T1-T4: }-5.4 \\
(-7.4-(-3.4)\end{array}$ & $<0.001$ \\
\hline $\begin{array}{l}\text { Subjektiv } \\
\text { hälsa }\end{array}$ & EQ-VAS & $\begin{array}{l}-15 \\
(-17- \\
(-12)\end{array}$ & $<0.001$ & $\begin{array}{c}-8.2 \\
(-11-(-5.5)\end{array}$ & $<0.001$ & $\begin{array}{l}\text { T1-T4: } 3.8 \\
(-0.19-7.7)\end{array}$ & 0.062 \\
\hline \multirow[t]{3}{*}{$\begin{array}{l}\text { Kognitiva } \\
\text { funk- } \\
\text { tioner }\end{array}$} & MMSE & $\begin{array}{c}-1.5 \\
(-2.1- \\
(-0.089)\end{array}$ & $<0.001$ & $\begin{array}{c}-0.17 \\
(-0.42-0.75)\end{array}$ & 0.581 & $\begin{array}{l}\text { T1-T4: } 1.2 \\
(0.43-2.0)\end{array}$ & 0.003 \\
\hline & $\begin{array}{l}\text { Kognitiv } \\
\text { snabbhet }\end{array}$ & $\begin{array}{c}-0.19 \\
(-0.32- \\
(-0.052)\end{array}$ & 0.006 & $\begin{array}{c}0.0086 \\
(-0.13-0.15)\end{array}$ & 0.902 & $\begin{array}{l}\text { T1-T4: } 0.19 \\
(-0.041-0.42)\end{array}$ & 0.106 \\
\hline & $\begin{array}{l}\text { Exekutiv } \\
\text { funktion }\end{array}$ & $\begin{array}{c}-0.21 \\
(-0.37- \\
(-0.053))\end{array}$ & 0.009 & $\begin{array}{c}-0.016 \\
(-0.18-0.15)\end{array}$ & 0.846 & $\begin{array}{l}\text { T1-T4: }-0.025 \\
(-0.25-0.30)\end{array}$ & 0.857 \\
\hline $\begin{array}{c}\text { Sociala } \\
\text { funk- } \\
\text { tioner }\end{array}$ & $\begin{array}{l}\text { Frekvens } \\
\text { ensamhet }\end{array}$ & $\begin{array}{c}0.44 \\
(0.30-0.59)\end{array}$ & $<0.001$ & $\begin{array}{c}0.30 \\
(0.15-0.46)\end{array}$ & $<0.001$ & $\begin{array}{c}\text { T1-T4: } \\
0.00069 \\
(-0.32-0.32)\end{array}$ & 0.997 \\
\hline $\begin{array}{c}\text { Psykisk } \\
\text { funktion }\end{array}$ & $\begin{array}{l}\text { Depres- } \\
\text { sivitet, } \\
\text { GDS-15- } \\
\text { poäng }\end{array}$ & $\begin{array}{c}1.8 \\
(1.5-2.2)\end{array}$ & $<0.001$ & $\begin{array}{c}1.1 \\
(0.62-1.6)\end{array}$ & $<0.001$ & $\begin{array}{l}\text { T2-T4: } 0.48 \\
(-0.13-1.1)\end{array}$ & 0.124 \\
\hline
\end{tabular}

Anmärkningar: ${ }^{a}=$ Diagonal kovariansstruktur; ${ }^{b}=$ korrigerat för kön, somatisk multisjukdom och tid. Andra variabler än P-ADL och I-ADL korrigerades även för I-ADL. ${ }^{c}=$ Beräkningar på basen av ordinala data från mätvågor T1 till T4, med undantag för variabeln depressivitet för vilken utfallsvariabeln bara motsvarade mätvågor T2 till T4, eftersom T1-värdet var oberoende variabel $i$ analysen.

Även variabeln tid eller ålder var associerad till en lägre (23\% eller 5.4/24p) ADL-förmåga, vilket dock korrigerades för i de förra beräkningarna. Förekomsten av SSD var signifikant associerad med försämrade kognitiva förmågor (MMSE, kognitiv snabbhet respektive exekutiv funktion) över tid, men när man korrigerade för ADL-förmåga och andra störfaktorer var dessa 
kognitiva försämringar, tvärtemot våra hypoteser inte längre signifikanta. Förutom att högre GDS-poäng vid baslinjemätningen enligt LMM-analyser ökade risken för ökad depressivitet vid efterföljande mätvågor, så visade separata analyser även på kategorinivå att förekomst av SSD istället för ND vid baslinjen signifikant ökade den kombinerade risken för SSD och depression vid efterföljande mätningar (figur 8).

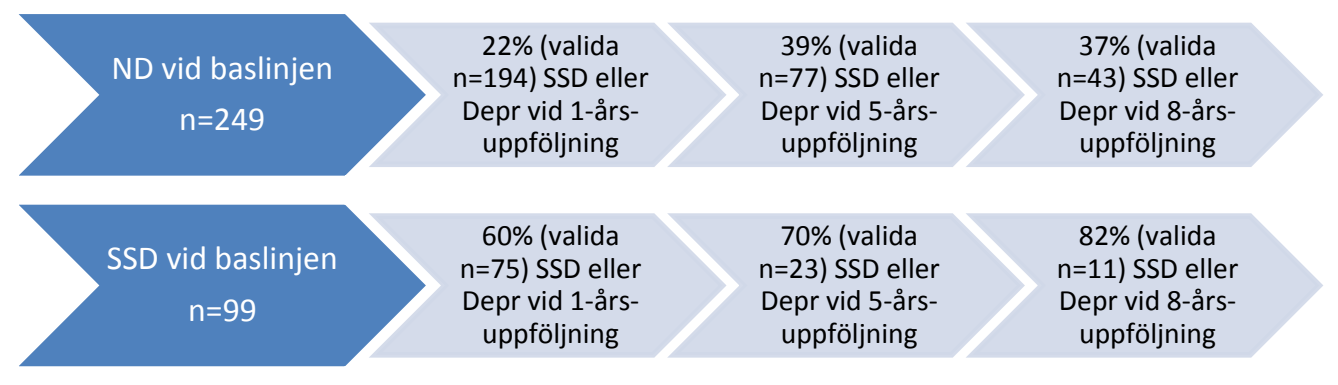

Figur 8. Den kombinerade proportionen av SSD och depression vid varje mätvåg, för personer som haft ND eller SSD vid baslinjen. Anmärkning: Proportionerna skiljde sig signifikant mellan $N D$ vid baslinjen och SSD vid baslinjen för varje mätvåg, med $\chi^{2}=37(p<0.001)$ vid 1årsuppföljning, $\chi^{2}=6.7(p=0.010)$ vid 5-årsuppföljning, och $\chi^{2}=7.0(p=0.008)$ vid 8 årsuppföljning.

Beträffande dödlighet, så var förekomst av SSD associerad med 60\% högre dödlighet, enligt inledande univariat cox-regression (Tabell 9). När man däremot korrigerade för relevanta kovariater i den multivariata cox-regressionen var bara tre oberoende faktorer signifikant associerade med överlevnad eller död, nämligen manligt kön, lägre kognitiv snabbhet, och lägre I-ADL- funktioner. 
Tabell 9. Dödlighet som funktion av olika data från baslinjen som oberoende variabler, analyser med univariat and multivariat cox-regression med $n=371^{\mathrm{a}}$.

\begin{tabular}{|c|c|c|c|c|}
\hline & \multicolumn{2}{|c|}{ Univariat regression } & \multicolumn{2}{c|}{ Multivariat regression } \\
\hline & Hazard Ratio $(\mathbf{C I})$ & p-värde & Hazard Ratio (CI) & p-värde \\
\hline Manligt kön & $1.21(0.936-1.56)$ & 0.146 & $1.38(1.02-1.86)$ & $\mathbf{0 . 0 3 5}$ \\
\hline Utbildning, n år & $0.999(0.965-1.04)$ & 0.963 & $1.01(0.969-1.05)$ & 0.698 \\
\hline $\begin{array}{c}\text { Somatisk } \\
\text { multisjukdom (n } \\
\text { sjukdomar) }\end{array}$ & $1.13(1.05-1.22)$ & $\mathbf{0 . 0 0 2}$ & $1.07(0.981-1.16)$ & 0.130 \\
\hline SSD_vs_ND & $1.56(1.14-2.12)^{\mathrm{b}}$ & $\mathbf{0 . 0 0 5}$ & $0.915(0.298-2.81)^{\mathrm{c}}$ & 0.867 \\
\hline Depr_vs_ND & $1.31(0.753-2.29)^{\mathrm{d}}$ & 0.329 & $1.25(0.426-3.67)^{\mathrm{c}}$ & 0.674 \\
\hline P-ADL & $0.737(0.668-0.813)$ & $<\mathbf{0 . 0 0 1}$ & $0.930(0.801-1.08)$ & 0.338 \\
\hline I-ADL & $0.941(0.924-0.958)$ & $<\mathbf{0 . 0 0 1}$ & $0.952(0.926-0.980)$ & $\mathbf{0 . 0 0 1}$ \\
\hline EQ-VAS & $0.991(0.984-0.998)$ & $\mathbf{0 . 0 1 2}$ & $1.08(0.997-1.02)$ & 0.161 \\
\hline MMSE & $0.952(0.929-0.976)$ & $<\mathbf{0 . 0 0 1}$ & $1.03(0.978-1.09)$ & 0.238 \\
\hline Kognitiv snabbhet & $0.701(0.609-0.806)$ & $<\mathbf{0 . 0 0 1}$ & $0.764(0.634-0.919)$ & $\mathbf{0 . 0 0 4}$ \\
\hline Exekutiv funktion & $0.777(0.676-0.894)$ & $\mathbf{0 . 0 0 1}$ & $0.939(0.736-1.20)$ & 0.599 \\
\hline Ensamhet 1-2 & $1.23(0.874-1.72)$ & 0.238 & $1.20(0.837-1.71)$ & 0.326 \\
\hline Ensamhet 1-3 & $1.52(1.01-2.11)$ & $\mathbf{0 . 0 1 2}$ & $1.38(0.939-2.02)$ & 0.101 \\
Ensamhet 1-4 & $1.18(0.646-2.14)$ & 0.595 & $1.07(0.525-2.19)$ & 0.850 \\
\hline
\end{tabular}

Anmärkningar: ${ }^{a}=$ Slutlig modell byggde på $n=371$, av vilka 238 (64\%) avled, och $133(36 \%)$ som var censurerade observationer. Fem automatiska imputeringar gjordes i alla oberoende variabler med bortfall, i enlighet med metoden Fullt villkorlig specificering (Fully conditional specification) i SPSS. Antal imputerade värden var 64 för variabeln kognitiv snabbhet, 132 för variabeln Exekutiv funktion, samt lägre antal i övriga variabler. Antal fall tillgängliga för den multipla Cox-regressionen var 163/371 (44\%) före, och 371/371 (100\%) efter multipel imputering. ${ }^{b}=$ Utan imputeringar $i$ denna variabel var HR $1.60(1.21-2.11)$ och $p=0.001$ i den univariata regressionen. ${ }^{c}=$ Med en alternativ ordinal variabel (inklusive alla tre kategorierna ND, SSD och Depr; utan några imputerade värden) istället för de dikotomiserade variablerna ( $S S D$ vs ND) och (Depr vs ND) var resultaten i den multipla regressionen $H R=1.10$ (0.783-1.55) och $p=0.578$ för det kategoriska steget ND-SSD, och HR=1.03 (0.508-2.09) och $p=0.936$ för det kategoriska steget ND-Depr. ${ }^{d}=$ Utan imputeringar i denna variabel var HR 1.35 (0.794-2.30) och $p=0.268$ i den univariata regressionen. ${ }^{e}=$ Resultaten för variabeln ensamhet presenteras för varje kategoriskt steg: 1-2 motsvarande aldrig-sällan, 1-3 motsvarande aldrig-ibland, 1-4 motsvarande aldrig-ofta. 


\section{Diskussion}

\subsection{Tvärsnittsbilder av det komplexa området mellan normalt åldrande och depression}

Det övergripande syftet för avhandlingsprojektet var att undersöka och beskriva det oklara området mellan syndromal depression och ND hos äldre äldre personer, d.v.s. att undersöka subsyndromal depression (SSD) hos äldre äldre personer.

I den följande diskussionen kommer först resultaten från de olika delstudierna att diskuteras, och därefter följer en mer övergripande diskussion för att sätta studieresultaten $\mathrm{i}$ ett sammanhang.

\subsubsection{Upplevelser av tillvaron i ålderdomen, och heterogenitet inom depressivitet} I studie 1 beskrevs upplevelser av tillvaron hos äldre äldre personer med SSD, och deras upplevelser av tillvaron jämfördes med motsvarande upplevelser hos personer med ND respektive syndromal depression. De kvalitativa intervjuerna gav detaljrika beskrivningar av hur det är att leva med livets och kroppens nedgångar och andra utmaningar under ålderdomen, och hur flertalet personer ändå vill fortsätta hänga med i livet och samhället så länge man får leva relativt självständigt. Ålderdomen och det som har kallats för den fjärde åldern av livet ger nya förutsättningar i tillvaron, vilka man tvingas att förhålla sig till. Med hjälp av olika copingstrategier - som exempelvis att ta en dag i taget, d.v.s. att leva i nuet och inte bekymra sig över framtiden eller det förflutna - kunde de äldre äldre personerna uppleva en relativt bra tillvaro trots den sviktande kroppen eller funktionsnedsättningarna, andra utmaningar och sociala förändringar.

Tidigare har gjorts kvalitativa studier av hur det är att leva med depression [171-174], och det finns likheter mellan den föreliggande studien och dessa. Exempelvis finns det tydliga likheter mellan temat att "ta en dag i taget" i studie 1 och den rörelse framåt iväg från nedstämdhet och deprimerande miljöer, vilken beskrivs som en del av en kulturell modell av "personligt ansvar" för depression, enligt Switzer et al [173]. Liknande beskrivningar av temat om kroppens nedgång finns beskrivet i Fischer et al [175], där den kroppsliga förändringen beskrivs som en sorts bevis på förändring när identiteten i övrigt delvis är stabil hos den äldre personen. Beskrivningarna av tillvaron skiljde sig mer mot dem i Allan et al [174] där depression beskrivs i termer av bland annat självförakt och en kamp för livet. Dessa senare skillnader jämfört med andra studier kan vara uttryck för att studierna innehåller deltagare av olika kulturer eller subkulturer, olika individer, men det kan också vara uttryck för hur intervjufrågor ställts. För studie 1 valdes öppna frågor om tillvaron, för att vi på ett indirekt skulle få ökad förståelse om depressivitet, medan de exempelvis i Allan et al ställde frågorna mer direkt om depression vilket naturligt nog ger annorlunda beskrivningar.

Beskrivningarna av copingstrategier hos de äldre äldre personerna i studie 1 liknar även tidigare beskrivningar av inre styrka, och resilience-faktorer hos äldre med olika tankemässiga och 
beteendemässiga strategier $[50,60]$. Om coping och resilience finns en omfattande litteratur, med även angränsande psykologiska processer som hardiness, känsla av sammanhang, Styrke- och sårbarhetsintegration (Strength and Vulnerability Integration, SAVI), liksom sociologiska teorier om psykosociala åldrandeprocesser enligt aktivitetsteorin, disengagemangsteorin,

gerotranscendens, mm [54, 55, 61, 63, 64, 69]. Snarare än att någon av dessa teorier skulle vara universellt giltig eller mer korrekt än övriga avseende hur det är att åldras, så framstår det utifrån jämförelsen med intervjudata från studie 1 att dessa teorier var och en beskriver olika aspekter av åldrande och ålderdom.

Tillvaron hos äldre äldre personer innebär å ena sidan förutsättningar som är gemensamma utifrån kronologisk åldergrupp, biologisk och fysisk ålder, liksom generation (sekulär trend) och kultur/subkultur [70-72, 176], och å andra sidan individuellt olika upplevelser och preferenser. Genom att lyssna på den individuella berättelsen kan vi få ledtrådar som är avgörande eller kritiska för att förstå vad som ger livskvalitet eller depressivitet, och vad som ger kraft och hopp, eller brist på desamma. Den individuella berättelsen ger på detta sätt viktig information att beakta vid bedömning av den psykiatriska patienten under ålderdomen för diagnostik - vid sidan av det mer DSM-baserade räknandet av antal symtom och duration - och behandling med val mellan KBT, läkemedel, fysisk aktivitet, reminiscensterapi eller annat. Genom uppmärksammandet av den individuella berättelsen kan vi öka precisionen i diagnostik, men möjligen också precisera behandlingsval så att det blir både kausalt träffsäkert på individnivå och personcentrerat med beaktande av den äldre personens preferenser och subjektiva förståelse av sitt tillstånd [177].

Vid jämförelsen mellan de olika kategorierna av depressivitet framkom i studie 1 mycket likheter, $\mathrm{t}$ ex att samtliga identifierade fyra teman kunde återfinnas i respektive kategori av depressivitet. Detta talar för att både förutsättningar, upplevelser av tillvaron, liksom hanterande av livet kan vara likartat i ålderdomen oavsett om man har ND, SSD eller syndromal depression. Dock framträdde även skillnader, där skillnaderna mellan SSD och ND verkade vara av diskret kvantitativ art, medan skillnaderna mellan SSD och depression däremot även verkade vara av delvis kvalitativ art. Exempelvis var upplevelser av kroppslig nedgång och dess negativa konsekvenser mer framträdande med stora begränsningar socialt och fysiskt bland personer med syndromal depressivitet jämfört med SSD, medan upplevelser av självständighet å andra sidan föreföll svagare. Slutsatser i studien var bl a att det således kanske inte bara är kvantitativa skillnader utan även kvalitativa skillnader mellan SSD och syndromal depression, vilket kan styrka föreställningen om en naturlig gräns mellan normalitet och patologi som sammanfaller med gränsen mellan SSD och syndromal depression. Även tidigare studier har pekat på kvalitativa skillnader mellan kategorier av depressivitet, där man exempelvis pekat på olika symtomprofiler vid olika grader av depressivitet [178, 179]. Detta anknyter även till diskussionen om de båda konkurrerande perspektiven om dimensionellt eller kategoriskt perspektiv på affektiva sjukdomar, där det kategoriska perspektivet motsvarar förekomsten av kvalitativa skillnader medan det dimensionella perspektivet istället motsvarar föreställningen om affektiva 
sjukdomar och affektiva enskilda symtom som grader på en kontinuerlig skala, vilket visualiserats i figur 3 (kapitlet introduktion ovan).

Diskussionen om det kategoriska och det dimensionella perspektivet på affektiva sjukdomar eller enskilda depressiva symtom anknyter även till andra aspekter av heterogenitet vid depressiva tillstånd. DSM-systemet från versionerna III och framåt har hittills byggt på kriterier som främjar en acceptabel reliabilitet vid värdering av depressiva symtom. Samtidigt finns en förhoppning om att framtida diagnosregister också skall beakta olika etiologier då SSD och syndromal depressivitet inte är inbördes homogena tillstånd utan snarare övergripande etiketter på heterogena tillstånd.

I denna anda har flera författare undersökt subgrupper av depressivitet [180]. Exempelvis har Carracher et al 2009 funnit tre subgrupper av depression, medan Fried \& Nesse 2015 i det stora $(n=3703)$ STAR*D-materialet identifierat inte mindre än 1030 olika symtomprofiler eller varianter av depression [181, 182]. Givetvis skulle resultat som detta kunna få en psykiater att misströsta om varje symtomprofil av depressivitet också skulle motsvara behov av en specifik behandlingsmetod, eftersom det skulle bli svårt att hålla reda på alla dessa olika subgrupper och

behandlingar. Å andra sidan kan samma resultat påminna oss om att våra nuvarande diagnostiska metoder ännu är under utveckling, och långsiktigt i behov av omarbetning och förfining för att förhoppningsvis bättre kunna vägleda våra och patienters frågor om prognos och behandling $\mathrm{i}$ framtiden. Förutom nuvarande nio diagnostecken som sammanställdes i DSM-registret, så finns även andra tecken på depressivitet (t ex enligt skattningsskalan IDS-30 (The Inventory of Depressive Symptomatology) med 30 olika symtom; [183]), och förutom indelning på basen av antal depressiva symtom, eller grad av lidande eller funktionsnedsättning, så har även föreslagits andra kriterier för indelning, $t$ ex förekomsten av markörer för komplicerad sjukdom [184], eller olika förloppsmodeller (unipolär och bipolära affektiva varianter [185, 186]).

\subsubsection{Bilder av depressivitet hos äldre äldre personer, typiska eller atypiska?}

Återkommande har även föreslagits att äldre och äldre äldre personer med depressiva tillstånd har en annorlunda symtombild än yngre personer. Exempelvis har beskrivits ett

"uttömningssyndrom" (depletion syndrome) eller "depression utan ledsenhet" där socialt disengagemang och anhedoni är framträdande, och vaskulär depression med kännetecken av apati, förlångsamning och kognitiv svikt, och även andra etiketter på atypiska sjukdomsbilder hos äldre personer [94, 187].

Emellertid har det empiriska underlaget för en generellt annorlunda symtomprofil hos äldre personer varit bristande, och i en nylig kritisk litteraturgenomgång av Haigh et al 2018 argumenteras för att en annorlunda symtomprofil i huvudsak skulle kunna förklaras av högre fysisk komorbiditet i högre åldrar [89]. Om man även beaktar det transkulturella perspektivet, inklusive olika psykosociala skillnader mellan kulturer och subkulturer, liksom mellan generationer (sekulär trend), så finns förmodligen ytterligare förklaringsvärde till eventuella åldersskillnader i symtombild [71, 188]. Med andra ord kan föreställningen om en generellt 
annorlunda och mer atypisk symtombild av depressivitet hos äldre personer vara något som stämmer endast om man utgår från en hegemonisk och förenklad bild av det depressiva syndromet, och bortser från exempelvis fysisk samsjuklighet och transkulturella aspekter i mötet med den enskilda personen. Mer korrekt skulle det kanske vara att beskriva äldre personers symtombild vid depression som mer varierande än för yngre, där både fysisk samsjuklighet och transkulturella aspekter måste beaktas vid bedömningen av den individuella symtombilden. Studie 1 belyser således på basen av informationsrika kvalitativa intervjuer hur tillvaron och ålderdomen upplevs och hanteras av äldre äldre personer med SSD, vilket bidrar till vår förståelse av SSD och har konsekvenser för vårt förhållningssätt från omgivningen.

I denna kontext kan även resultaten från studie 2 få en särskild relevans, då identifierade faktorer som var associerade till SSD skulle kunna vara företeelser eller tecken som vid sidan av DSMkriterierna kan hjälpa oss att identifiera eller åtminstone öka vår vaksamhet för möjlig förekomst av SSD och depressivitet hos en äldre person. I mötet med en patient som bär på markörer eller associerade faktorer till SSD och depressivitet, (t ex förekomst av tidigare stroke, nedsatt ADLförmåga, och tankar av oro för framtiden) så bör vi i enlighet med resultat från studie 2 höja vår vaksamhet för depressiva symtom. Med vår kunskap om att det inte bara är de nio symtomen ur DSM-kriterierna som räknas, samt med vår kunskap om att komorbiditet och transkulturella aspekter komplicerar bilden av depressivitet hos äldre så kan vi med sådan ökad vaksamhet bli mer sensitiva och öka chanserna att adekvat diagnosticera när det föreligger signifikant depressivitet, d.v.s. minska risken för falskt negativa fall i mötet med äldre personer.

Studie 2 byggde på vissa sätt vidare efter studie 1 på frågan om huruvida det egentligen föreligger endast kvantitativa eller även kvalitativa skillnader mellan ND, SSD och syndromal depression. Eftersom vissa markörer eller faktorer var associerade till kategorier av depressivitet endast vid binärlogistisk regression och inte vid efterföljande ordinallogistisk eller linjär regression, så vore en möjlig slutsats (i linje med resultat från studie 1) att det kan föreligga både kvantitativa och kvalitativa skillnader mellan kategorierna. Om det enligt ett strikt dimensionellt perspektiv hade varit endast kvantitativa skillnader mellan dessa kategorier av depressivitet, så borde konsekvent samtliga associerade faktorer falla ut signifikant både vid binärlogistiska regressioner och ordinallogistiska och linjära regressioner, men så blev inte fallet. Emellertid hade studie 2 metodologiska begränsningar som medför att vi inte med säkerhet kan säkerställa både kvantitativa och kvalitativa skillnader. Exempelvis var antalet individer mindre och variansen större i kategorin syndromal depression jämfört med ND och SSD, vilket bör ha bidragit till den relativa styrkan i respektive association, och detta kan i förlängningen ha bidragit till att resultaten indikerade kvalitativa skillnader. Dock verkar det å andra sidan inte orimligt om våra fynd av kvalitativa skillnader mellan subgrupper eller kategorier av depressivitet korresponderar med verkligheten, om man beaktar diskussionen om heterogenitet bland depressiva tillstånd med exempelvis studien av Fried \& Nesse [181].

I det ovanstående har delstudier 1 och 2 diskuterats, och även om de motsvarade helt olika metodologier, så kan bägge studier sägas ha indikerat den samtidiga förekomsten av kvantitativa 
och kvalitativa skillnader mellan kategorierna av depressivitet - ND, SSD och syndromal depression. Därtill belyste bägge dessa studier hur SSD kan presenteras hos äldre äldre personer, i en kontext av tilltagande kroppslig nedgång med associerade funktionsnedsättningar, ett tilltagande hjälpbehov och med inslag av existentiella frågor i den s.k. fjärde åldern av livet. En möjlig tolkning av studieresultaten kan vara att personal i sjukvård och omsorg följaktligen behöver höja blicken från de klassiska depressionskriterierna och beakta den individuella berättelsen och omständigheterna om vi skall lyckas fånga upp signifikant depressivitet när den föreligger.

Studie 2 kunde varken bekräfta eller vederlägga förekomsten av de fyra teman som identifierades i den kvalitativa studie 1, eftersom vi för studie 2 prioriterade bort operationaliseringen av dessa teman - och istället prioriterade att undersöka faktorer som har ett starkare vetenskapligt stöd från litteratur om SSD hos yngre, respektive syndromal depression hos äldre äldre personer. Att med en kvantitativ och deduktiv ansats vidare studera dessa fyra identifierade teman från studie 1 vore således en möjlighet som tillhör framtiden.

\subsection{Longitudinella aspekter av SSD bland äldre äldre personer}

\subsubsection{Dynamiken och relevansen av SSD bland äldre äldre personer}

Medan både studie 1 och 2 kan sägas ha studerat subsyndromal depression hos äldre äldre personer ur ett tvärsnittsperspektiv på diagnostik och på själva fenomenologin av SSD, så skall vi nu i det följande vända oss till hur vi med studierna 3 och 4 i ett mer longitudinellt perspektiv undersökte utvecklingen för personer med SSD bland äldre äldre personer. För att bättre besvara avhandlingens syfte om att beskriva SSD hos äldre äldre personer, så ville vi förutom med fenomenologiska beskrivningar även beskriva SSD utifrån dess prediktiva värde.

Eftersom affektiva tillstånd på ett dynamiskt sätt varierar i symtomprofil och intensitet över tid hos en enskild individ, så blir det även av detta skäl viktigt att studera tillstånden longitudinellt. Är verkligen SSD relevant i ett kliniskt patientmöte i vård eller omsorg, eller i ett större samhällsperspektiv, om det nu bara är en tillfällig krusning av det affektiva tillståndet hos en person i ett längre perspektiv? En kritisk invändning vore i detta sammanhang att det inte går att studera SSD longitudinellt på ett säkert sätt, eftersom individen går mellan de olika kategorierna av depressivitet över tid ([15]; figur 9 ). Vi har valt att ändå genomföra sådana studier, även om vi med ödmjukhet ser att metoden med ett fåtal observationer av depressivitet över tid inte fullständigt förmår att fånga de minsta detaljerna av stämningslägets naturligt snabba variationer. 


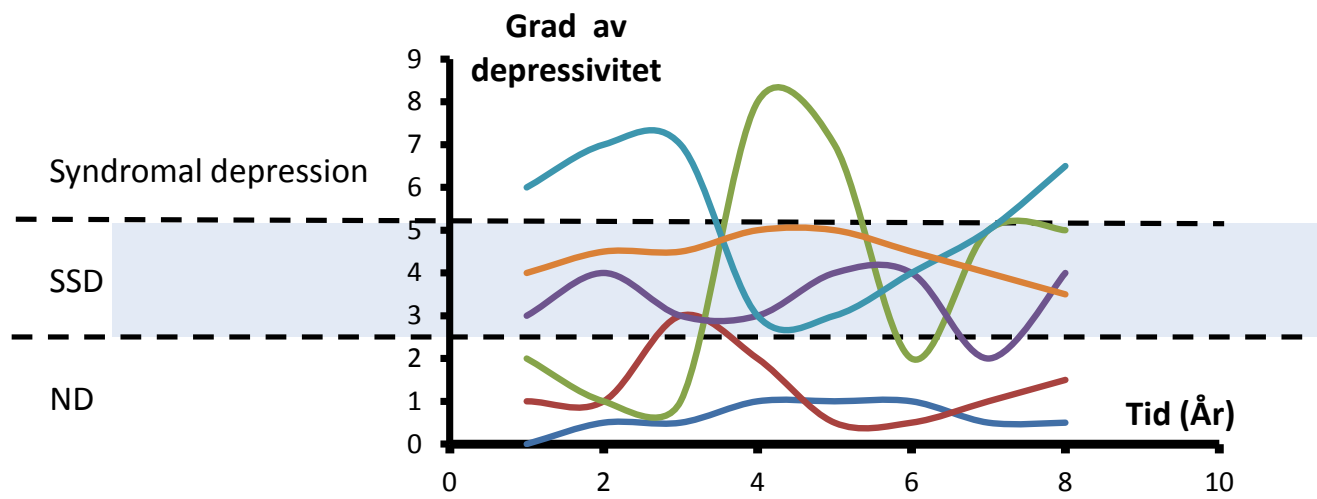

Figur 9. Dynamiken i affektiva tillstånd: grad av depressivitet varierar per individ över tid.

I studie 3 undersöktes hälsoekonomiska konsekvenser av SSD jämfört med ND med hjälp av registerdata av direkta kostnader och sjukvårdskonsumtion över fem års tid. Ett centralt fynd var att förekomst av SSD vid antingen baslinjen eller vid 1-årsuppföljningen (SSD Ever) motsvarade en signifikant högre genomsnittlig totalkostnad per månad av överlevnad för en individ, jämfört med dem som hade ND vid bägge mättillfällen (ND Both). Förutom totalkostnaderna, så var bland annat följande delkomponenter av kostnader också signifikant högre: primärvård, slutenvård, läkemedel, kommunal omsorg.

En mycket grov skattning av de högre sammanlagda samhällskostnaderna per år för SSD jämfört med ND hos äldre äldre personer i Sverige är 4.3 miljarder SEK, eller 0.43 miljarder Euro (givet 258471 personer i åldern 85+, och de associerade kostnaderna 81.3 miljarder SEK (eller 8.16 miljoner Euro) under 2015 för summan av sjukvård och kommunal omsorg för dessa personer $)^{1}$ $[189,190]$.

\footnotetext{
${ }^{1}$ Denna grova skattning av samhällskostnader för SSD hos äldre äldre personer förklaras mer i detalj i det följande. Populationen av personer med ålder 85 år eller mer var 258471 i Sverige 2015. Antalet personer per åldersgrupp mer i detalj var 162108 (ålder 85-89)+ 76013 (ålder 90-94)+ 18454 (ålder 95-99)+ 1896 (ålder 100+). Medelkostnaden per individ för summan av sjukvård och kommunal omsorg var 20132015 i Västra Götalandsregionen 258400 SEK (medel för åldrar 85-89), 380800 SEK (medel för åldrar 90-94), 514000 SEK (medel för åldrar 95-99), och 506000 SEK (medel för åldrar 100+). Genom att multiplicera antal personer med medelkostnaden för respektive åldersgrupp och därefter summera, så skattades för hela populationen i ålder 85+ den totala kostnaden till 81.279 miljarder SEK år 2015. Med antagandet om $12 \%$ prevalens av SSD, så skrevs ekvationen $(0.88 \mathrm{x}+0.12 \mathrm{y}=81.279)$, där $\mathrm{x}$ var kostnader för ND, medan y var kostnader för SSD. Med antagandet om en faktor 1.45 för överskjutande kostnader av SSD jämfört med ND enligt resultaten i studie 3 (vilket förmodligen är en underskattning av kommunala kostnader), skrevs ekvationen $\mathrm{y}=1.45 \mathrm{x}$. Tillsammans gav dessa ekvationer att $\mathrm{x}=77.115$, och
} 
Tidigare har man visat liknande resultat för yngre personer med SSD [131, 132], liksom för äldre äldre personer med depression [191-193], men vår studie indikerar alltså att detta mönster tycks gälla även för SSD i de högsta åldrarna. Vid jämförelsen mellan syndromal depression vid något av dessa två mättillfällen (Depr Ever) och ND Both fanns motsvarande signifikanta skillnader för totalkostnaderna, medan sambanden ej var signifikanta för andra delkomponenter av sjukvårdskostnader än primärvård. Att sambanden var icke-signifikanta för flera delkomponenter i jämförelsen mellan Depr Ever och ND skulle möjligen kunna förklaras av ett mindre antal personer och därmed generellt lägre statistisk styrka i beräkningarna för gruppen Depr Ever. Tidigare studier har diskuterat olika förklaringar till varför personer med depressiva symtom har ökade samhällskostnader, varav några är att de psykiatriska symtomen själva leder till extra behandlingar, att depressiva symtom är associerade med utvecklingen av vissa ospecifika somatiska symptom, och att depressiva symtom komplicerar behandlingen av somatiska sjukdomar t ex genom mindre patientmedverkande till behandlingen [193-197].

En möjlig slutsats från vår studie hade i förlängningen varit att dessa ökade samhällskostnader för SSD bland äldre äldre personer borde motivera extra resursfördelning till denna grupp av personer i samhället, för att bättre hantera samhällsproblem av sådan relativt stor signifikans. Emellertid är det en viktig poäng att studier om samhällskostnad för en sjukdom (cost-of-illness (COI)) inte nödvändigtvis bör vägleda fördelning av resurser i samhället, eftersom fördelningen kanske snarare bör vägledas av vilka interventioner som gör nytta (genom t ex kostnadsnyttoanalyser som ofta mäts i enheten kostnad per QUALY (quality adjusted life years), och kostnadseffektivitetsanalyser med mer varierande enheter) för olika samhällsproblem [163, 198]. Emellertid kan COI-studier som föreliggande studie 3 bidra till att belysa den psykiska ohälsans relevans i ett samhällsekonomiskt perspektiv: SSD är i hög grad relevant i ett sådant perspektiv, trots att det oftast inte motsvarar någon dramatisk sjukdomsbild. Denna relevans blir särskilt tydlig om man beaktar den högre förekomsten av SSD i samhället, jämfört med syndromal depressivitet.

Ännu en detalj som möjligen skulle styrka relevansen av SSD bland äldre äldre personer i samhället är det som åtskilliga tidigare studier visat, nämligen att depressivitet bland äldre personer i högre utsträckning än bland yngre personer går oupptäckt och odiagnostiserad [89, 199, 200]. Detta torde betyda att en större andel av beräknad samhällskostnad för SSD och syndromal depression i samhället kvarstår hög, medan en mindre andel av motsvarande samhällskostnad hos yngre personer kvarstår, eftersom samhällskostnad för yngre åldersgrupper generellt mer aktivt reduceras genom olika former av hjälpinsatser och behandling [199, 201]. Tecken i vår studie 3 som möjligen skulle indikera ett sådant mönster av mindre interventioner

$\mathrm{y}=111.817$. I en hypotetisk situation med bara ND (utan någon SSD) i samhället, så skulle totalkostnaden bli 77.115 miljarder istället för 81.279 miljarder, vilket innebär att prevalensen på 12\% SSD i samhället motsvarar överskjutande kostnader på 4.164 (81.279-77.115) miljarder SEK. Med beaktande av en inflation på 2.80\% enligt konsumentprisindex från år 2015 till 2017, så blir skattningen med 2017 års prisnivåer 4.281 (4.164 x 1.0280) miljarder SEK. Med växelkursen $9.96 \mathrm{SEK}=1 €$ för juni 2018, så motsvarar 4.281 miljarder SEK 0.430 miljarder Euro. 
från sjukvården för äldre personers psykiska ohälsa var att endast 0.1 procent av alla sjukvårdskontakter under fem år utgjordes av besök i specialistpsykiatrin, vilket t.ex. kan jämföras med ett genomsnitt på $9 \%$ för vuxna personer av alla åldrar i Sverige [202]. Socialstyrelsen beskrev i en rapport 2012 att en högre andel av personer med psykisk ohälsa bland äldre personer jämfört med yngre i Sverige går oupptäckta och odiagnostiserade, och om de söker hjälp så får de snarare hjälp i primärvård istället för specialiserad psykiatri. Därtill får de generellt också mindre adekvat hjälp, med mindre psykoterapi och mer läkemedel oavsett individuella behov och preferenser [203]. Att de äldre äldre personerna i vår studie hade så låg frekvens kontakter med specialistpsykiatrisk sjukvård kan ha många förklaringar, varav några som diskuterats i tidigare studier är att äldre personer med psykisk ohälsa snarare söker hjälp för fysiska åkommor istället för psykiska, att det finns barriärer i kommunikation mellan äldre patienter och sjukvårdspersonal, och att psykisk sjukdom ger stigmatisering socialt [196, 197, 204].

En inkonsistens i resultaten av vår studie 3 om hälsoekonomiska aspekter av SSD bland äldre äldre personer var att sjukvårdskonsumtionen, mätt som exempelvis antal sjukvårdsbesök inom primärvård, slutenvård och specialiserad öppenvård, inte var signifikant högre bland personer med SSD Ever eller Depr Ever jämfört med ND Both trots att de direkta kostnaderna för sjukvården var högre i motsvarande jämförelser. Denna inkonsistens i resultaten skulle kunna bero på karaktären av olika enskilda vårdkontakter, då vi i studie 3 inte beaktat vilka diagnoser som avhandlades vid respektive sjukvårdsbesök. Exempelvis skulle de enskilda besöken kunna ha varit av längre duration eller på annat sätt kostsammare för personer med SSD Ever eller Depr Ever jämfört med ND Both, vilket i så fall skulle förklara denna inkonsistens i resultaten.

På ett liknande sätt som resultaten i studie 3 indikerade relevansen av SSD hos äldre äldre personer utifrån hälsoekonomiska aspekter i samhället, så kan studie 4 sägas indikera relevansen av SSD hos äldre äldre personer utifrån fysiska och psykosociala aspekter. Studie 4 undersökte hur SSD jämfört med ND var associerat med en rad olika utfallsmått över åtta års uppföljning, och några resultat var att SSD hade signifikant association till lägre ADL-funktion, lägre subjektiv hälsa, lägre kognitiva funktioner, och högre grad av ensamhet och depressivitet, även om sådana associationer till kognitiva funktioner inte längre var signifikanta när man korrigerat för störfaktorer. Även dödligheten var signifikant förhöjd för personer med SSD jämfört med ND enligt den univariata regressionen, men denna association försvann när man kontrollerade för relevanta kovariater. Sammantaget indikerar dessa fynd att SSD jämfört med ND tycks vara associerat med allvarliga hälsoproblem över längre tid, även om symtombilden vid SSD sällan är dramatisk, och även om durationen av den affektiva episoden inte alltid är så lång.

Tidigare studier har visat att SSD och lindriga depressiva tillstånd liksom syndromal depression är associerat med dylika negativa utfall i yngre åldrar [35, 36, 138, 205, 206], men få studier har påvisat sådana samband bland äldre äldre personer. Beträffande dödligheten bland personer med SSD i åldersgruppen, så har tidigare studier också visat divergerande resultat, vilket gör vår studie särskilt relevant. I Leiden 85+ studien var SSD och depression associerade med mortalitet 
endast bland personer med ensamhet [207], och i BASE-studien av Rapp et al var effekten av SSD och depression på mortalitet signifikant bland yngre äldre, men inte bland äldre äldre personer [208].

Blazer et al 2001 framförde att depressivitet bland äldre personer möjligen bara har effekt på dödlighet indirekt genom flera intermediära variabler, vilket skulle betyda att associationen mellan mortalitet och depressivitet skulle gå mot noll om man korrigerar för relevanta kovariater [209]. I kontrast till Rapp et al i BASE-studien, så fann vi att det fanns ett signifikant samband mellan SSD och mortalitet när vi bara kontrollerade för kön och samsjuklighet. Emellertid avtog detta samband i vår studie när vi la till kovariaten I-ADL, och därför drog vi (liksom Rapp et al) slutsatsen att det finns ett oberoende samband mellan SSD och mortalitet i lägre åldrar, men inte bland äldre äldre personer [23, 208, 210]. Detta fynd överensstämmer också med studien av Blazer et et al 2001, även om den studien genomfördes på mestadels yngre personer [209].

\subsubsection{Om longitudinella associationer till SSD, och om kausalitet}

Beträffande associationerna mellan SSD och olika former av sjuklighet kan man ställa frågan om dessa är kausala samband eller inte - orsakar detta till synes lindriga tillstånd SSD verkligen dessa starka negativa effekter i det långa loppet? För att besvara denna fråga behöver vi då först diskutera begreppet kausalitet och dess innebörd. En ofta refererad beskrivning av kausalitetsbegreppet är de kriterier som presenterades av Sir Bradford Hill 1965 [211]. Dessa var 1) styrkan i associationen, 2) konsistens mellan olika studieresultat, 3) specificitet för associationen, 4) temporalitet, 5) biologisk gradient, 6) rimlighet och 7) koherens med övrig vetenskap. Efter Hills beskrivning har kriterierna diskuterats och reviderats i olika omgångar och en modern kondenserad uppsättning kriterier kan återfinnas i Lewis 2011, där man uteslutit ovanstående punkter tre och sju, förutom att kriteriet temporalitet framhålls som det mest elementära [212].

Man kan dela in i fyra principiella typer av kausala samband, varav ett flertal förekommande samband i naturen räknas till gruppen "icke-nödvändiga, icke tillräckliga" kausalsamband medan t ex nödvändiga men icke-tillräckliga kausalsamband är mer ovanliga och återfinns inom bland annat infektionsmedicin med tuberkelbakteriens betydelse för sjukdomen tuberkulos som ett konkret exempel [28]. Ofta talar man om riskfaktorer istället för kausalfaktorer (eller orsaker), eftersom det är ovanligt under naturliga förhållanden att hitta faktorer som svarar mot alla kriterier för kausalitet. Andra koncept som bidrar till att uttrycka komplexiteten av kausalitet i kontexten av psykisk ohälsa är "multipla nivåer av kausalitet" (vilket syftar på när man expanderar epidemiologisk forskning både "upp" till större sociala kontexter, och "ned" till biologiska mekanismer) och den s.k. spindelvävsmodellen för kausalitet, där ett ofta stort antal faktorer påverkar varandra sinsemellan i ett nät av associationer till ett konsekvent utfall ([213215]; Figur 10). En invändning mot likställande mellan riskfaktorer och kausala faktorer vore att vissa av dessa riskfaktorer bör betraktas som mediatorer (eller annars moderatorer) snarare än kausala faktorer, då vissa faktorer kanske bara är mellansteg i en kedja av händelser i naturen. Sådana invändningar är svåra att fullständigt vederlägga varför de behöver finnas med vid design, 
genomförande och analys av framtida forskningsstudier. Invändningarna kan i vissa fall bemötas med att sambanden i flera fall tycks vara bidirektionella eller reciproka mellan depressivitet och andra faktorer [96, 216, 217]. Om ett samband går i bägge riktningar, t.ex. att en föregående nedsättning av ADL-förmåga leder till senare ökande depressivitet och även vice versa att en föregående depressivitet leder till en konsekvent nedsättning av ADL-förmåga, så framstår komplexiteten i de naturliga sambanden tydligt. En möjlig tolkning skulle vara att det inte helt säkert går att veta vad som är kausalitet, omvänd kausalitet eller sammanblandning av faktorer (confounding). Hills kriterier och efterföljande varianter har i samma anda föreslagits mer som guidelines snarare än kriterier [212], eftersom vi med empiriska studier i naturen aldrig kan nå $100 \%$ säkerhet om kausalitet.

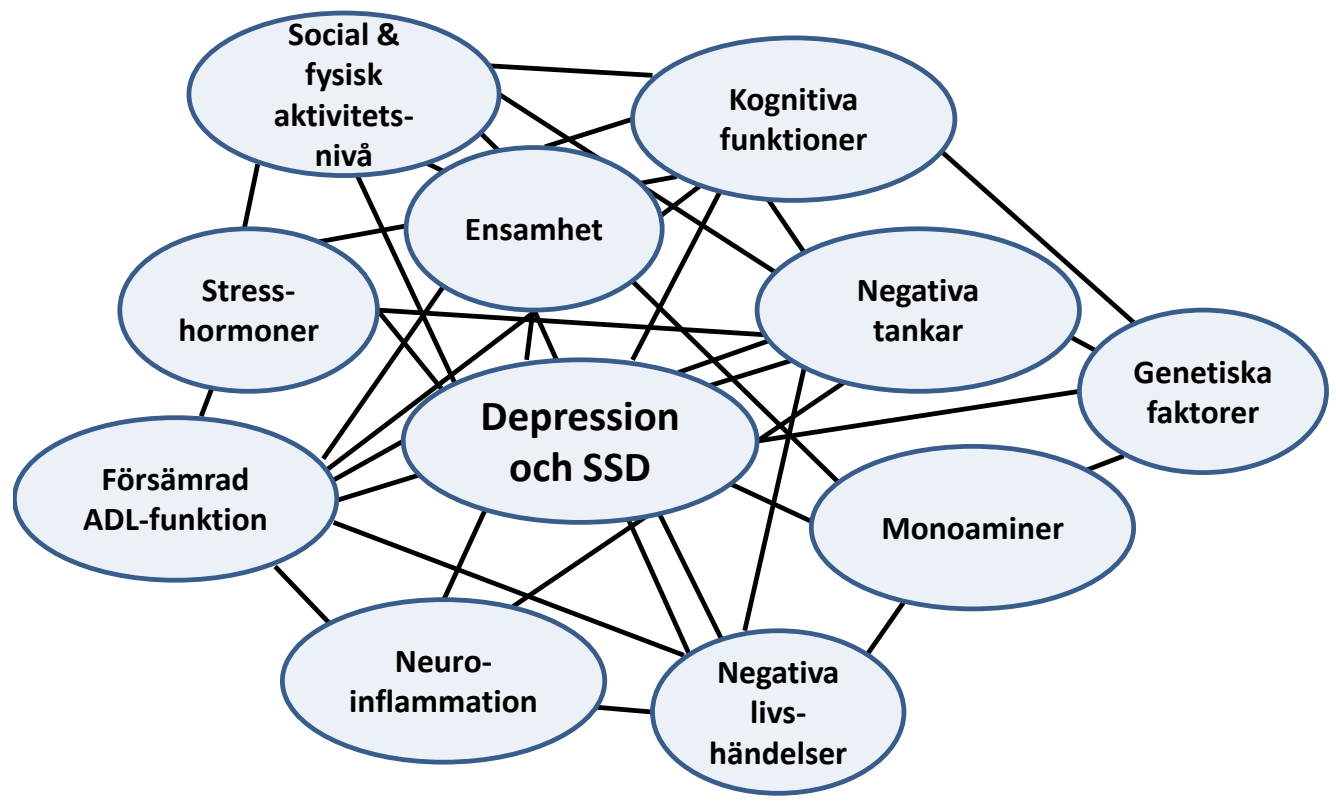

Figur 10. Schematisk illustration av spindelvävsmodellen i sammanhanget av depression och SSD

Utifrån vår studie skulle temporalitet, rimlighet och viss relativ styrka i associationerna kunna tala för kausalitet, men några avgörande detaljer som gör att vi som helhet ändå inte gör anspråk på kausalitet i funna associationer är att tidsintervallen mellan depressionsmätning och utfall är så långa, varför temporalitetskriteriet kan ifrågasättas. Genom tätare mätningar av exponering och utfall med fler mätvågor torde man med större säkerhet kunna uttala sig om kausalitet $\mathrm{i}$ sambandet, något som man på ett förtjänstfullt sätt exemplifierat i en studie om sambandet mellan ADL och depression av Chen et al 2012 med mätningar vartannat år under en 10-årsperiod [218], 
och i en annan studie av Fishleder et al 2016 om förloppsmodeller av depressivitet med månatliga mätningar av depressivitet under en sexmånadersperiod [219].

Ett oväntat fynd i vår studie 4 apropå kausalitet och bidirektionella samband, var att det inte återfanns någon signifikant skillnad i kognitiva utfall mellan SSD och ND över tid när man kontrollerade för potentiella störfaktorer. Tidigare studier i yngre urvalsgrupper har indikerat ett generellt bidirektionellt samband mellan kognitioner och depressivitet, vilket exempelvis syns i att depressiva episoder tycks leda till påverkade hjärnstrukturer med exempelvis reducerad storlek av hippocampus [96, 217, 220-222]. Varför det inte syntes något signifikant samband i vår studie skulle kunna förklaras av relativa interaktiva statistiska effekter av samsjuklighet, eller differentiellt bortfall av deltagare i studien (vilket kommenteras närmare i stycket 5.4.2 om intern validitet).

Sammanfattningsvis pekar resultaten i studier 3 och 4 på att SSD jämfört med ND hos äldre äldre personer är relevant både ur ett hälsoekonomiskt perspektiv, och avseende sjuklighet över längre tid. I linje med tidigare studier fann vi ett univariat samband mellan SSD och dödlighet bland äldre äldre personer vilket försvann när vi kontrollerade för relevanta kovariater. Eftersom bägge studier undersökte skattningar av depressivitet i tidigt skede av kohortstudien medan utfallet mättes under en efterföljande tidsperiod så skulle det kunna tala för att utfallen liknar kausala konsekvenser enligt en mer komplex förståelse av kausalitet, men designen av studierna var återigen inte utformade för att värdera frågan om kausalitet.

\subsection{Betydelsen av SSD bland äldre äldre personer, och riskerna med medikalisering}

\subsubsection{Betydelsen av SSD hos äldre äldre personer för patienten, för sjukvården och för samhället}

Vad som ger särskild betydelse till våra studieresultat i ett samhällsperspektiv, och till fenomenet SSD hos äldre äldre personer, är att andelen äldre äldre personer växer i den aktuella demografiska utvecklingen i världen. Därtill talar prevalenssiffror för att SSD är kanske tre gånger vanligare än syndromal depression, varför summan av effekter från de två tillstånden på samhällsbefolkningen därmed kan vara lika stor. Detta kan formuleras som att andelen av ohälsa eller bristande livskvalitet i befolkningen (population attributable fraction) är lika stor av SSD som av syndromal depression. En möjlig metafor till storleksförhållandet mellan syndromal depression och SSD är bilden av isberget (figur 11) - den kliniska depressionen som vi i klinisk praxis diagnosticerar motsvarar den synliga mindre delen av isberget ovanför vattenytan, medan den subkliniska eller subsyndromala depressionen som vi i klinisk praxis inte diagnosticerar eller behandlar istället motsvarar den från luften osynliga och större delen av isberget. 


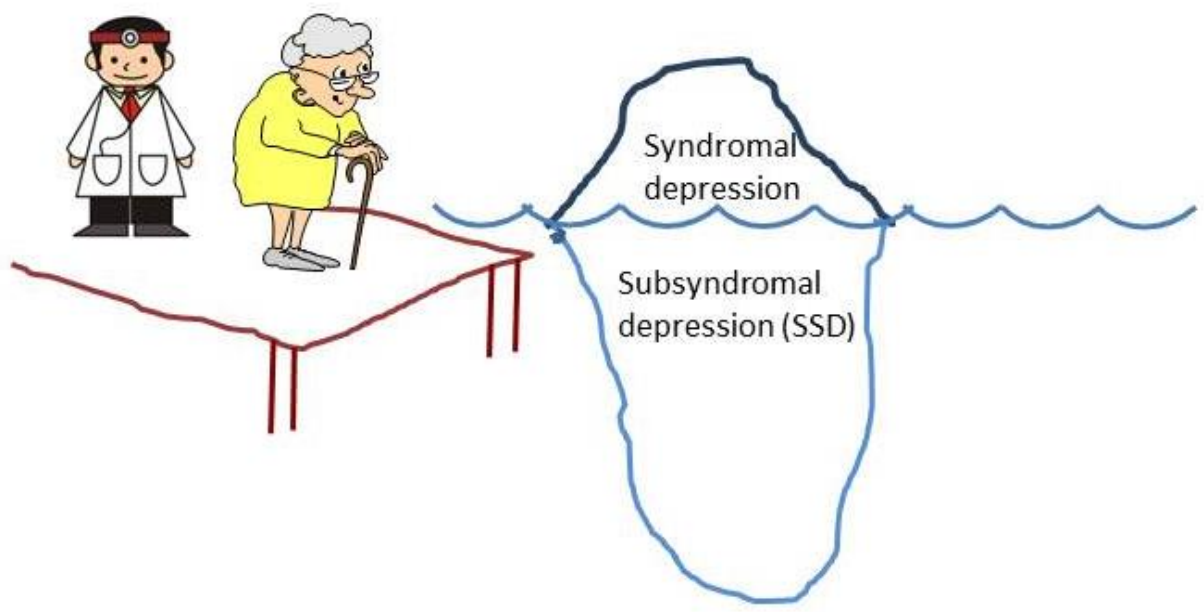

Figur 11. Metaforen med isberget, som ett sätt att illustrera att SSD är mer vanligt men mindre synligt än syndromal depression

Möjligen är signifikansen av SSD rentav särskilt stor just bland äldre personer jämfört med yngre, då en del studier funnit att SSD är mer vanligt i äldre åldersgrupper jämfört med yngre vuxna [89, 223]. Men även om andelen ohälsa i befolkningen skulle vara större för SSD än för syndromal depression, så innebär det ju inte nödvändigtvis att SSD bör diagnosticeras eller behandlas.

\subsubsection{Normalitet, medikalisering och diagnostik}

Att ställa en sjukdomsdiagnos kan i vårt samhälle vara fördelaktigt för individen, eftersom både medicinsk behandling och försäkringssystem till stor del bygger på medicinska diagnoser. Det är dock inte självklart att man borde ställa sjukdomsdiagnos och behandla SSD bara för att det är associerat med lägre livskvalitet, ökade sociala problem, ökad fysisk och psykisk sjuklighet, eftersom betydelsen av dessa associationer möjligen storleksmässigt kan betraktas som små för den enskilda individen, medan det samtidigt finns nackdelar med både diagnosticering och behandling. Exempel på nackdelar av en sjukdomsdiagnos kan vara stigmatisering av psykisk ohälsa, att individen passiviseras eller kanske börjar praktisera en offerroll genom den sociala sjukrollen, eller konsekvensen att personen med SSD vid en diagnos genom sjukvården skulle ordineras antidepressiva behandlingar som återkommande ger biverkningar - i sällsynta fall av sådan valör att det leder till antingen somatiskt eller psykiatriskt relaterad sjukhusvård och $\mathrm{to} \mathrm{m}$ död [127, 224-226]. I detta sammanhang kan vi påminna oss att sjukdomar brukar beskrivas utifrån tre olika aspekter: den medicinsk-positivistiska eller objektiva aspekten (disease), den subjektiva aspekten (illness) hos individen, och den sociala aspekten (sickness) i relation till medmänniskor, grupp och kultur [225, 226]. 
Huruvida man bör betrakta SSD som ett sjukdomstillstånd är således inte självklart. Traditionellt har det haft som medicinsk och social konsekvens att man blivit berättigad behandling om man passerat gränsen till sjukdom. I många fall gäller detta även idag, då behandlingsforskning liksom försäkringsregler alltså bygger på medicinens stipulerade etiketter eller diagnoser. Ur ett sociologiskt perspektiv innebär den sociala sjukrollen både plikter och privilegier [225]. Normer kopplas till sjukdomsbegreppet och sjukdomsdiagnoserna, och plikter kan vara att kalla sig sjuk men också att medverka till samhällets rekommenderade behandling, medan privilegier kan vara att man i samhället och kulturen t ex får en större legitimitet för vila och extra stöd med en sjukdomsdiagnos. Inom fältet psykiatrisk sjukdom ser sjukdomsrollen lite annorlunda ut jämfört med somatisk sjukdom, då det generellt finns inslag av sådant stigma (negativa sociala effekter som kopplas till innehav av diagnos), och då dessa mindre synliga mentala sjukdomar skapar mindre legitimitet till vila och passivitet jämfört med somatiska och mer synliga sjukdomar och skador [226]. Därtill kan interaktioner mellan sickness, illness och disease vara starkare när det kommer till psykiatrisk sjukdom jämfört med somatiska sjukdomar som t ex en höftfraktur.

Interaktioner mellan olika aspekter av ett tillstånd kan också vara starkare för psykiska tillstånd jämfört med somatiska tillstånd. Exempel på sådana interaktioner kan vara när läkare anpassar valet av intygsdiagnos i ett intyg enligt vad det aktuella försäkringssystemet premierar [personlig erfarenhet], varvid social sickness skapas, vilket kan leda till subjektiv illness hos individen. Ett annat exempel vore när en persons subjektiva illness vid sjukvårdsbesök felaktigt bedöms som objektiv disease, vilket efter personalens utlåtande leder till en diagnos och konsekvent social sickness.

Enligt teoribildningen social konstruktionism så motsvarar diskussionen och våra föreställningar om diagnoser och sjukdomar ett skapande och omskapande av samma sjukdomar i samhället [227, 228]. På så sätt konstruerar människor i social interaktion föreställningar om sjukdomen både hos den sjuke och hos omgivningen, i en dialog eller förhandlingsprocess mellan den sjuke och omgivningen. I dagens samhälle har dialogen förändrats jämfört med tidigare, $t$ ex då den förs mer i sociala medier vilket får specifika effekter på sickness, illness och disease, exempelvis då människor dagligen kommunicerar sina psykiatriska diagnoser sinsemellan på medier som Facebook och liknande [229, 230]. Genom att definiera en företeelse som sjuk eller avvikande, så medför detta alltså i en social interaktion att samma företeelse i någon mån går från normalitet till patologi i sina konsekvenser (motsvarande det så kallade Thomasteoremet [231]). Subjektiv illness tolkas som objektiv disease, vilket leder till social sickness, vilket i sin tur påverkar och förändrar de ursprungliga aspekterna illness och disease. Om vi således skulle välja att kalla SSD för ett sjukdomstillstånd, så skulle det därmed innebära att vi kopplar en uppsättning sociala normer till tillståndet - med privilegier och skyldigheter.

Tendensen att vi definierar alltmer i vårt samhälle som sjukdom istället för normalitet eller hälsa har beskrivits som medikalisering [232, 233], i nära anknytning till den socialkonstruktionistiska teorin, och kritiker har framfört att det exempelvis leder till en passivisering av individer, och även ökad makt till sjukvården i samhället när man i medikaliseringens tecken omdefinierar och 
expanderar depressionsbegreppet. I detta sammanhang kan det noteras att man på senare tid börjat tala alltmer om "psykisk ohälsa" vid sidan av psykisk eller mental sjukdom, och det förra kan sägas motsvara en vidare eller expansiv definition av depression [234]. Möjligen kan man också samtidigt skönja uttryck för en motsatt tendens i samhället, något som skulle kunna kallas demedikalisering.

DSM-systemet som i nuläget motsvarar ett rådande kategoriskt diagnostiskt paradigm i psykiatrin internationellt har likheter med Linnés klassificeringssystem historiskt, där man klassificerade olika entiteter i olika separata kategorier ungefär som olika fack eller hinkar bredvid varandra [5]. Förutom att det alternativa dimensionella perspektivet på psykiatriska sjukdomar indikerar problemet med svårigheten att skilja mellan normalitet och sjukdom, så finns även problemet med psykiatrisk komorbiditet. Samsjuklighet mellan psykiatriska sjukdomar är generellt omfattande, vilket för individen kan innebära att man får olika diagnoser år från år, eller annars att man får en lång rad diagnoser samtidigt - en praktik som också är olika mellan olika läkare [27, 235]. I ett epidemiologiskt perspektiv är detta en viktig bidragande förklaring till kraftigt varierande prevalenssiffror för olika psykiatriska sjukdomar, eftersom prevalensen av depression i en specifik studie är helt beroende av om psykiatrisk samsjuklighet exkluderas eller inte vid datainsamlingen.

Kritiker har lite populärt jämfört DSM-systemet inom psykiatribranschen med McDonalds hamburgerkedja inom hamburgerbranschen: det är inte nödvändigtvis så att bästa reliabilitet alltid motsvarar bästa kvalitet. Som en fortsättning på kritiken mot nuvarande psykiatriska diagnossystem har beskrivits förhoppningar att man i framtida diagnossystem (ICD-11, DSM-6) skall kunna bygga diagnoser mera på etiologi istället för topografi [236], och några exempel är hur man neurokemiskt, neuroanatomiskt, och genetiskt försökt att kategorisera sjukdomar transdiagnostiskt inom psykiatrin, och med motsvarande försök även inom modern psykologi och psykoterapi (t ex med den s.k. hexaflex-modellen inom Acceptance and Commitment Therapy) även om det därvid inte kallats för sjukdom utan exempelvis istället "destruktiv normalitet" [235, 237, 238]. För att frigöra sig från nuvarande DSM-systemets ramar så talar man om transdiagnostiska system och fenotyper eller undergrupper av psykologisk/psykiatrisk problematik [16, 235]. Även detta avhandlingsprojekt kan sägas vara del av en sådan strävan att förstå och beskriva psykiska problem transdiagnostiskt eller bortom diagnoserna i den oklara zonen mellan normalt åldrande och depression/patologi. Därmed bidrar föreliggande text till en ständigt pågående social konstruktion och rekonstruktion av vårt samhälle, med samtidiga och inbördes motriktade tendenser till medikalisering och demedikalisering enligt diskussionen ovan.

Relationen mellan förespråkare för olika perspektiv i denna polemik om hegemoniska diagnosmodeller, sjukdomsförståelse och medikalisering har återkommande varit spänd, vilket lett till att idéströmningar som kritiserat rådande paradigm i psykiatrin har kallats för antipsykiatri [239]. Eftersom den antipsykiatriska rörelsen historiskt i huvudsak har definierats av representanter för psykiatrin, och då ämnesområdet psykiatri är ytterligt omfattande så har det som kallats antipsykiatri av naturliga skäl varit heterogent både mellan tidigare representanter 
och senare. Under lång tid har denna debatt lett till ett reducerat samarbete mellan psykiatrin och andra närstående discipliner (sociologi, psykologi) [232]. Inom psykiatrin har funnits liknande debatt där debattörer problematiserat aktuella diagnosgränser, t ex från ett dimensionellt perspektiv. Förutom att frågan om gränsen mellan normalitet och patologi har debatterats inom psykiatriska och s.k. antipsykiatriska perspektiv, så är frågan tillämplig även inom den somatiska sjukvårdens domäner, där exempelvis diagnosgränser ändras över tid [30].

Efter ovanstående utvikning om gränsdragningen mellan normalitet och sjukdom, så drar undertecknad den preliminära slutsatsen att SSD inte säkert motsvarar vare sig normalitet eller sjukdom eftersom detta kan vara en fråga om såväl kultur som språkbruk, försäkringsmedicinska praktiker, medicinska vetenskapliga fynd, hegemoniska diagnosmodeller och konsekventa interaktioner mellan objektiva, subjektiva och sociala aspekter av sjukdom. En alternativ formulering vore att SSD hos en äldre äldre person i det enskilda fallet kan bedömas endera som normalt åldrande eller sjukdom. Oavsett vilket, så indikerar avhandlingsprojektet att SSD hos äldre äldre personer har signifikans för både den enskilda individens hälsa och sjuklighet över tid.

Med hänsyn till att SSD och depression har både en hög prevalens och särskilt en högre incidens än många andra sjukdomstillstånd i befolkningen, så har de jämförts med luftvägsinfektioners effekt på hälsan, och Schaefer et al 2017 jämförde retoriskt på detta sätt episoder av mental sjukdom med infektioner som bronkit och influensa [240]. Bilden av bronkit (Figur 12) kan alltså bidra till att illustrera SSD hos äldre äldre personer ur ett epidemiologiskt perspektiv.

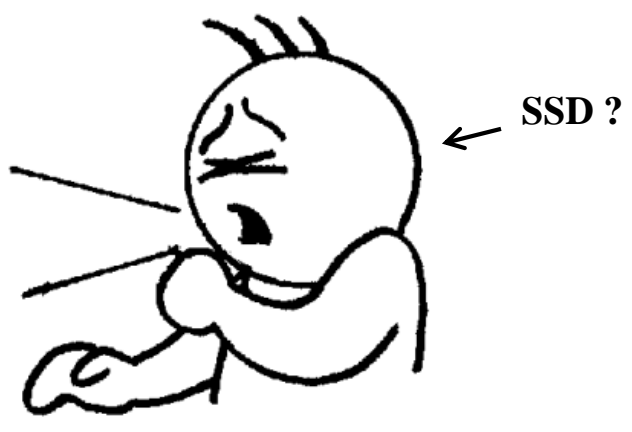

Figur 12. Metaforen om depressivitet som själens bronkit, som en motsvarighet till kroppens bronkit - på basen av tillståndens epidemiologiska likheter. 


\subsubsection{Prevention och behandling av SSD hos äldre äldre personer}

I viss mån är signifikansen av SSD hos äldre äldre personer i samhället också beroende av vilka möjligheter det finns till interventioner. Om det inte hade funnits några interventioner som gör skillnad vid SSD, så vore det mindre relevant att försöka identifiera detta tillstånd av lindrig depressivitet. Det finns idag behandlingsmöjligheter för SSD, men någon internationellt erkänd behandlingsmodell för behandling av SSD finns inte i nuläget. Detta beror förmodligen delvis på bristen på consensus kring definitionen av begreppet, och delvis också för att det inte genomförts så mycket behandlingsstudier för tillståndet [21]. Tidigare studier som undersökt behandlingseffekter vid SSD och lindrig depressivitet bland yngre vuxna indikerar att gängse depressionsbehandling med exempelvis KBT eller läkemedelsgruppen SSRI möjligen fungerar för SSD precis som för svårare grader av depressivitet. Dock har effektstorlekarna generellt varit mindre vid SSD än vid syndromal depression [106-108].

För syndromal depression i den specifika åldersgruppen äldre äldre personer finns inte heller några specifika riktlinjer, men däremot för den större åldersgruppen äldre personer >65år [109]. Vanligt förekommande behandlingar som visat effekt är bl a KBT och undergruppen Problemlösningsterapi, antidepressiva läkemedel, fysisk aktivitet, och Collaborative care [109, 110]. I bristen på evidens för den specifika åldersgruppen äldre äldre personer väljer vissa förespråkare en mer nihilistisk hållning, d.v.s. att man kan välja att göra vad som helst eller ingenting med likvärdigt vetenskapligt stöd - eftersom det ändå inte finns några säkra evidens för behandling. Ovanstående litteraturgenomgång av Kok et al 2017 och tidigare litteratur propagerar däremot återkommande för en hållning där man försöker att extrapolera evidens från yngre åldrar även till äldre äldre personer [109, 122, 123]. I likhet med vårt tidigare resonemang om heterogenitet i genes och klinisk bild, så finns det skäl att försöka beakta såväl komorbiditet och transkulturella aspekter vid vårt behandlingsval, förutom att detta val också bör väga in individens egna preferenser [241, 242].

Exempelvis skulle man då välja KBT eller Problemlösningsterapi om det framkommer psykosociala aspekter ur anamnesen som kan hanteras konstruktivt, eller fysisk aktivitet om det finns någorlunda fysiska förutsättningar, eller annars välja läkemedel om patienten så föredrar. Liksom vid syndromal depression och andra psykiska tillstånd kan det vid SSD även utifrån hälsoekonomiska och etiska perspektiv finnas skäl att överväga stepped-care-modeller vid utformande av prevention och behandling i sjukvården [27, 82, 117]. Därtill finns skäl att även överväga mer sammansatta behandlingsmodeller av integrativ karaktär liknande Comprehensive Geriatric Assessment (CGA) och Collaborative care, vilka har fått ett växande stöd inom äldrepsykiatri, allmänpsykiatri och geriatrik [110, 114, 116, 243]. Dessa och liknande behandlingsmodeller framstår särskilt lämpliga för äldre personer med SSD eftersom de bygger på holism och personcentrerad vård vilket generellt passar bra vid komplexa multifaktoriella tillstånd, vars förekomst i sin tur är en grundregel hos äldre äldre personer med äldrepsykologiska och äldrepsykiatriska besvär. 
Sammanfattningsvis avseende behandling och prevention av SSD hos äldre äldre personer, så finns bristande vetenskapligt stöd men extrapolering av behandlingsrekommendationer från yngre åldersgrupper inklusive stepped-care-modeller liksom användning av mer holistiska eller multimodala behandlingsmodeller - liknande CGA och Collaborative care - framstår som rimliga och lovande alternativ. Med små men individanpassade insatser kan ofta lindriga psykiska besvär förbättras, medan terapisvikt eller mer kraftiga besvär motiverar mer omfattande interventioner.

\subsection{Metodologisk diskussion}

Validiteten eller giltigheten (överensstämmelse mellan verklighet och tolkning) för denna avhandling, eller för frågan om avhandlingens delarbeten har bidragit till att uppnå deras övergripande syften är beroende av ett flertal aspekter, vilka skall kommenteras i det följande. Syftet för avhandlingen var att undersöka och beskriva det oklara området mellan syndromal depression och ND hos äldre äldre personer, d.v.s. att undersöka subsyndromal depression (SSD) hos äldre äldre personer. När vi inledningsvis formulerade syfte för avhandlingen och satte ett likhetstecken mellan det oklara området och SSD, så blev detta länge efteråt mitt teoretiska antagande. Med tiden har jag så småningom insett att SSD och det oklara området inte nödvändigtvis är detsamma varför validiteten av vår definition av SSD, respektive validiteten för avhandlingsprojektet som helhet presenteras separat i det följande.

\subsubsection{Validiteten för operationaliseringen av begreppet SSD i avhandlingen}

Validiteten för begreppet SSD bland äldre äldre personer kan utifrån psykometriska principer beskrivas enligt följande delkomponenter [12]:

1. Innehållsvaliditet (d.v.s. hur adekvat valet av domäner och enskilda frågor är för syftet, hur mätinstrumentet täcker av studieområdet på ett övertygande sätt) beror mycket på valet av GDS-15 (Appendix, bilaga 1) för att operationalisera SSD i avhandlingens studier. Att likställa SSD med ett specifikt poängintervall av GDS-15-skattning är en förenkling av verkligheten, eftersom SSD eller det omtalade oklara området inte säkert fångas av instrumentet. När det gäller GDS-15-instrumentets sammansättning av frågor så finns detta väl beskrivet tidigare, och instrumentets validitet för att mäta depression är noga undersökt i många studier, även om flertalet genomförts i andra länder än Sverige [147, 148]. Vi valde aktivt att använda 15-frågeversionen GDS-15 istället för den i svensk geriatrisk verksamhet mer utbredda GDS-20 (eftersom GDS-20 tycks ha utformats och testats på svagare metodologiska grunder jämfört med 15-frågeversionen), eller den ursprungliga 30-frågeversionen av testet [150, 244, 245]. En aspekt av GDS-15instrumentet är att detta instrument liksom många andra skattningsskalor innehåller frågor där svaren påverkas tydligt av kroppsliga besvär (även om strävan vid konstruerandet av skattningsskalan var att just undvika sådana frågor). Exempelvis fråga nio om att pröva nya sysselsättningar, och fråga 13 om energinivå påverkas ofta på detta sätt, Detta innebär att risken finns att positiva svar på GDS-15 i själva verket står för somatisk sjukdom, trots att vi strävat efter att mäta psykiska besvär. Å andra sidan kan affektiva tillstånd generellt sägas ha både somatiska och psykiska komponenter, vilket motiverar att man faktiskt 
inkluderar frågor om somatiska aspekter för att fånga alla delar av det affektiva tillståndet. För att öka validiteten utifrån den dynamiska karaktären av depressiva tecken, så valde vi för delarbete 2 att definiera SSD-gruppen utifrån 2 separata mätningar med GDS-15, varför den studien således skiljer sig från övriga arbeten avseende innehållsvaliditet. Dessutom ändrades cutoff mellan ND och SSD från 1/2p till 2/3p i GDS-15 mellan delarbete 1 och följande arbeten vilket också innebär en variation i innehållsvaliditet mellan studierna.

2. Kriterievaliditet eller empirisk validitet (bestående av bl a samtidig validitet):

- Samtidig validitet: Eftersom användandet av en skattningsskala för att identifiera en kategori av depressivitet är väl etablerat enligt befintliga litteraturgenomgångar så framstod detta som ett ändamålsenligt och praktiskt sätt att mäta depressivitet och SSD i kohortstudien ELSA85 och konsekvent i föreliggande delarbeten [21]. En invändning är att ett mer konsekvent användande av DSM-kriterierna för depressivitet vore ett mer valitt tillvägagångssätt eftersom DSM ofta brukar betraktas som gold standard. Eftersom det dock inte i DSM finns någon riktig konsensus i valet av definition för SSD, så framstod valet av operationalisering mindre självklart, och utifrån det dimensionella perspektivet på psykiatrisk sjukdom så har skattningsskalor tydliga fördelar jämfört med strukturerad diagnostisk intervju, förutom att GDS-15 är lättare att administrera t ex eftersom det kan administreras av personal utan specifik utbildning. En principiell nackdel med GDS-15 är dock att skattningsskalan inte främst är utformad för att fånga SSD eller för att gradera depressivitet, utan istället för att värdera förekomst av syndromal depression (kategoriskt utfall), vilket är ett konceptuellt problem [12]. Dessutom påverkas det positivt prediktiva värdet för GDS-15-testet av prevalens i befolkningen, vilken ju skiljer sig väsentligt mellan SSD och syndromal depression. Således kan vi konstatera att GDS-15 användes för att definiera SSD för avhandlingens delarbeten, trots att instrumentet inte är utformat för att definiera SSD, vilket innebär åtföljande risker för att vi faktiskt studerat något delvis annorlunda än avsett.

3. Begreppsvaliditet (den grad i vilken mätinstrumentet relaterar till andra teoretiskt relaterade instrument som också kan mätas, eller eventuell korrelation respektive diskriminerande förmåga till andra tester och begrepp) har inte stått i centrum för denna avhandling, även om sådana aspekter behandlas i diskussioner av enskilda delarbeten, liksom i föreliggande ramberättelse. 


\subsubsection{Intern validitet för avhandlingsprojektet som helhet:}

\subsubsection{Kvantitativa kriterier för värdering av validiteten}

Validiteten för de enskilda studierna eller för avhandlingsprojektet som helhet är hur väl studierna och avhandlingen undersökte det avsedda, samt deras frihet från bias. Det finns åtminstone två sorters principiella bias i dessa forskningsstudier:

1. Selektionsbias:

○ Icke-deltagande var ett väsentligt problem för kohortstudien ELSA85, då 24\% ( $n=154 / 650)$ av den valbara befolkningen valde att avstå deltagande. Huruvida denna selektion var differentiell eller ej är ovisst. Jämförelser med jämnåriga personer för hela landet visade att studiedeltagarna hade en något lägre utbildningsnivå, men likartad könsfördelning som jämnåriga i landet (studie 4). Således kan vi inte med säkerhet veta om urvalet är representativt för den äldre äldre befolkningen i landet, även om demografiska data (tabell 2 i denna ramberättelse respektive tabell 1 i studier 1-4) vid baslinjen talar för en relativt god representativitet.

○ Uteblivna svar på enskilda frågor var generellt ett mindre problem för avhandlingen, då svarsfrekvensen var hög i flertalet variabler av kohortstudien. För studie 4 var det ett par variabler som hade större andel uteblivna svar, vilket hanterades med multipel imputering som ett sätt att minimera sådana effekter på analysen. I övriga analyser hanterades uteblivna svar med listvis exklusion vid beräkningar.

- Bortfall vid uppföljning (avhopp) var ett metodologiskt problem (särskilt för delstudier 3 och 4), vilket det ofta är i longitudinella studier av gamla personer pga sjukdom och död. I studie 4 gjordes en mer detaljerad analys (tabell 3), där det blev tydligt att bortfallet generellt motsvarade personer med bl a lägre ADL-nivå och kognitiv funktion, högre förekomst av särskilt boende, samt högre grad av depressivitet. Detta differentiella bortfall ökade risken för typ-2-fel, d.v.s. en risk för underskattning av reella samband [167].

2. Informationsbias eller observationsbias:

○ Förebyggande av informationsbias i studie 1 gjordes genom blindning för depressivitetskategori under steg 1-3 av innehållsanalysen.

- Reproduktion av förförståelse förebyggdes i studie 1 genom strukturerad arbetsmetod och reflexivitet.

- Minnesfel (recall bias) förebyggdes genom longitudinell design med flera mätvågor istället för tvärsnittsdesign, liksom användning av registerdata. Registerdata innebär principiellt felkällor som underrappportering (sensitivitet) och felkategorisering (specificitet), men inkluderade registerdata har i dessa studier bedömts högkvalitativa och motsvarande felkällor av ringa betydelse för avhandlingsresultaten. 
- Felklassificeringsbias var sannolikt ett relevant problem för avhandlingen, vilket motsvarar GDS-15-instrumentets bristande sensitivitet och specificitet vid operationalisering av SSD (ovan även kommenterat i termer av innehålls- och kriterievaliditet). Dock innebär GDS-15 en icke-differentiell felklassificering, vilket principiellt är ett mindre problem än differentiell - då det generellt leder generellt till utspädningseffekter och underskattning av sambanden, eller typ 2-fel istället för typ 1-fel [246].

- Svarsbias (att underrapportera eller överrapportera förekomsten av symtom pga skam, andra attityder och liknande, t.ex. vid rapport om alkoholkonsumtion eller känslor av nedstämdhet): Möjligen kan denna typ av informationsbias ha lett till felskattning av depressiva symtom, t.ex. att vissa personer nekade depressiva symtom fastän de egentligen hade sådana besvär. I studie 1 användes latent innehållsanalys, vilket minskade risken för detta bias då man i sådan analys försöker att tolka även subtila och mindre uttalade budskap av samtalet, och för övriga studier bedöms storleken av denna bias som begränsad med hänsyn till en generellt låg eller måttlig grad av stigmatisering av depressiva tecken i den aktuella kulturella kontexten.

Som ett sätt att förebygga bias mer generellt i avhandlingen, så har använts olika metoder i olika studier ( $\mathrm{t}$ ex kompletterande kvalitativ och kvantitativ metod, samt olika kompletterande statistiska metoder i studier 2-4), vilket kan kallas triangulering av metod eller mixed method i en vidare bemärkelse $[157,247,248]$. Emellertid var denna metod-triangulering inte i förväg avsedd att kompensera för något specifikt metodproblem utan syftet var snarare, mer övergripande, att göra avhandlingsarbetet och studiet av SSD så allsidigt som möjligt.

\subsubsection{Kvalitativa kriterier vid värdering av validiteten}

Inom kvalitativ metod finns delvis andra kvalitetskriterier för ett forskningsprojekt eller en studie. Trovärdighet i forskningen har beskrivits som ett mer övergripande kvalitetskriterium, med de fyra delaspekterna neutralitet eller bekräftelsebarhet (confirmability), stabilitet (dependability), kredibilitet (credibility) och transferabilitet [249].

1. Confirmability: hur väl resultaten överensstämmer med data, d.v.s. att en riktig tolkning har gjorts av data. Har adekvata statistiska tester använts, och har analysresultat tolkats korrekt? Även graden av neutralitet i forskarens arbete: reproduktion av egen förförståelse, eller adekvat naturalistisk öppenhet till vad data visar?

2. Dependability: stabilitet och instrumentell följdriktighet $i$ datainsamlingen över tid.

3. Credibility: Hur väl resultaten motsvarar en tillförlitlig och adekvat tolkning av data, hur väl fokus är på fenomenet som undersökts, och hur väl har kontexten beaktats. Credibility avser även hur väl har alternativa tolkningar av data värderats.

4. Transferabilitet motsvarar i grova drag extern validitet eller generaliserbarhet, vilket kommenteras i separat stycke nedan, inklusive frågor om urval och forskningsdesign. 
Av dessa fyra kvalitetskriterier från kvalitativ metodologi, så bedöms dependability ha varit ett mindre problem för avhandlingen, och för confirmability och credibility har vidtagits åtgärder fortlöpande i de respektive studierna för att maximera dessa kvalitetsaspekter (enligt metod, stycke 3.4 ovan). Under delarbete 1 var confirmability och risken att reproducera förförståelse en särskild utmaning, vilket vi förebyggde bl a med fältanteckningar, reflexiva anteckningar före och mellan intervjuer, korrekturläsning av transkripten, analys i enlighet med en väletablerad metod, samt valideringsdiskussioner i forskargruppen. Credibility har eftersträvats genom att producera manus för de olika delarbetena i dialog med övriga medförfattare, framställande av representativa citat $\mathrm{i}$ delarbete 1 respektive framställande av resultat $\mathrm{i}$ tabeller och figurer i övriga delarbeten, samt genom att presentera tolkning i kontext genom diskussionen i respektive manus.

Ytterligare kvalitetskriterier som föreslagits inom kvalitativ metod är även följande tre av Malterud 2001: reflexivitet, relevans och validitet [250]:

- Reflexivitet (hur forskningsprocessen istället för förförståelsen präglat resultaten, och forskarens aktiva strävan för medvetenhet om förförståelsen, d.v.s. perspektivmedvetenhet): Reflexiviteten har under avhandlingsarbetet eftersträvats genom särskilda reflexiva anteckningar under delarbete 1, och för samtliga delarbeten genom en bred litteraturgenomgång inklusive olika teoretiska perspektiv på depressivitet och normalt åldrande. Därtill har reflexiviteten eftersträvats i det gemensamma framställandet av olika manus, i dialog med övriga medförfattare.

- Validitet (vilket av Malterud beskrivs som hög kvalitet i design, datainsamling och analys, samt systematik det vetenskapliga arbetet, och att särskilt adressera potentiella felkällor): Ovan i stycke 5.4.1 har beskrivits några av de mått som vidtagits för att höja kvaliteten under datainsamling och analys. Ytterligare åtgärder för ändamålet vidtogs vid planerandet av den större kohortstudien ELSA85, där undertecknad deltog mycket begränsat i utformande av design, men lite mer i själva datainsamlingen. Beträffande design så bedöms populationsurvalet, användningen av högkvalitativa registerdata och den långa perioden av longitudinell uppföljning vara styrkor för validiteten i avhandlingsprojektet. Kombinerande av kvalitativ och kvantitativ metod inom ramen för avhandlingens delstudier bedöms ha stärkt avhandlingens validitet som helhet, och för delarbeten 2-4 användes ett flertal olika statistiska metoder parallellt, vilket bidrog till att adressera specifika felkällor. Exempel på sådant adresserande var korrigeringen för multipla jämförelser i studie 3, samt den mer detaljerade analysen av saknade data (missing data) i studie 4.

- Relevans eller betydelse (tillför resultaten något nytt och användbart i förhållande till tidigare teori och kunskap): Det har varit en genomgående strävan under avhandlingsarbetet att utgå från befintlig vetenskap vid planering, genomförande och analys i de olika delstudierna - men också att försöka problematisera funna resultat $\mathrm{i}$ förhållande till tidigare studier. Generellt har delstudierna tillfört ny kunskap då de samtliga utgått ifrån det relativa kunskapsgapet för SSD i åldersgruppen äldre äldre. 
Eftersom flera fynd i respektive delstudie dock till stora delar varit i linje med tidigare vetenskap, så har strävan blivit att försöka öka relevansen av studieresultaten särskilt mycket genom kritisk diskussion av de funna resultaten i deras kontext.

\subsubsection{Extern validitet, generaliserbarhet eller transferabilitet:}

I det ovanstående har beskrivits olika aspekter av intern validitet för vår operationalisering av SSD, respektive för avhandlingsarbetet som helhet. Den externa validiteten (eller generaliserbarheten eller transferabiliteten) är också avgörande för avhandlingens betydelse vetenskapligt, och motsvarar i vilken mån våra forskningsresultat är applicerbara eller projicerbara även till andra människor utanför det aktuella urvalet. Eftersom samtliga delarbeten bygger på en befolkningsstudie, så innebär detta att fynden bör vara generaliserbara till liknande befolkningar runtom i världen, vilket i huvudsak avser jämnåriga män och kvinnor med samma grader av depressivitet.

Generaliserbarheten begränsas av selektionsbias (beskrivet mer i stycke 5.4.2.1) med särskilt icke-deltagande och differentiellt bortfall som två relevanta problem, vilket tillsammans med den måttliga urvalsstorleken gör att man bör vara försiktig vid generalisering särskilt till vissa subgrupper av äldre äldre personer. Därtill bör depressivitet förstås i en kontext av kulturella och strukturella samhällsfaktorer, vilket gör att man även bör vara försiktig med att generalisera studieresultaten till andra geografiska områden. Exempelvis kan depressivitet utlösas av andra kulturella symboler i ett annat geografiskt område, vilket skulle påverka den relativa betydelsen för olika depressivitetsmarkörer (studie 2), och ge andra hälsoekonomiska konsekvenser i ett annat geografiskt område med en annan organisation av sjukvård och omsorg. Genom att presentera demografiska data, beskriva kontexten för olika delstudier, samt diskutera detaljerade studieresultat i deras kontext har vi försökt tydliggöra möjligheterna till generalisering för potentiella läsare, och möjligheterna att reproducera studierna för andra forskare. I grova drag bedöms urval och studiedesign i respektive studie medföra stora möjligheter till generalisering av resultat och slutsatser till gruppen äldre äldre personer med SSD i Sverige, och i närliggande länder.

\subsubsection{Reliabilitet för datainsamlingen i avhandlingsprojektet}

Förutom intern och extern validitet beskrivet ovan, så är reliabilitet eller reproducerbarhet och grad av mätningsbrus något som påverkar kvaliteten av studieresultaten. För delarbete 1 höjdes reliabiliteten genom eftersträvande av god och genomtänkt intervjuteknik, adekvat utformning av intervjuguide, noggrannhet i korrekturläsning och analys av intervjutranskript, mm. För de kvantitativa mätmomenten höjdes reliabiliteten genom träning av samtliga forskningsmedarbetare för datainsamlingen, och genom att i huvudsak använda väl beprövade och strukturerade bedömningsinstrument (GDS-15, EQ-5D, MMSE, strukturerad anamnestagning, mm) för mätningarna.

Ett särskilt problem avseende reliabilitet inom psykiatrisk forskning är studiedeltagarnas naturliga variation i förståelse av frågor, och deras förmåga att minnas och rapportera korrekta 
svar. Ett moment som förmodas ha höjt reliabiliteten av GDS-15-skattningar var att de ingående skattningsfrågorna ställdes muntligen av arbetsterapeut vid hembesök i respektive mätvåg, vilket därmed gav möjlighet till klargörande av frågornas innebörd vid behov under samtalet. Även beslutet att använda GDS-15-formuläret istället för alternativa skattningsskalor av depressivitet förmodas ha bidragit till en högre reliabilitet, eftersom instrumentet är utformat för att vara lättförståeligt även vid lindrig kognitiv svikt under ålderdomen. Ett ofrånkomligt problem för reliabiliteten vid studier av äldre äldre personer är naturligt förekommande kommunikationssvårigheter pga nedsättning av syn, hörsel, tal och kognitiva funktioner. Eftersom samtliga medarbetare vid datainsamlingen hade bakgrund som personal inom geriatrisk sjukvårdsverksamhet bedöms detta problem ha fått begränsad betydelse vid datainsamlingen.

\subsubsection{Några kommentarer om kausalitet utifrån avhandlingsprojektet}

Vid studier av SSD hos äldre äldre personer finns liksom i epidemiologiska studier generellt en strävan att identifiera kausalitet, eftersom sådan kunskap är avgörande för möjligheter till prevention av ohälsa i samhället. För att identifiera orsak eller etiologi till en form av ohälsa är dock ett första steg att värdera om det föreligger associationer i enlighet med våra föregående hypoteser, samt om sådana associationer är valida eller skenbara. Först därefter, och med adekvat design av studien kan man värdera om associationen är kausal eller om den förklaras av störfaktorer, samt vilken typ av kausalitet som föreligger. Flertalet tillstånd av psykisk ohälsa eller mental sjukdom har orsakssamband som motsvarar den typ av kausalitet som kallas varken tillräckliga eller nödvändiga faktorer, vilket också motsvarar spindelvävsmodellen för kausalitet (beskrivet i stycke 5.2.2 ovan).

Även om det finns relativt många vetenskapliga studier som undersökt depressivitet i yngre åldrar, med anspråk om kausala samband, så hade vi i våra delarbeten små förutsättningar att värdera temporala samband mellan SSD och associerade faktorer. Även om det förelåg tidssamband utifrån våra fyra mätvågor och åtta års uppföljning, så var tidsintervallen mellan mätvågorna långa och oregelbundna. Det framstår sannolikt att graden av depressivitet varierat väsentligt även mellan mätvågorna, varför det finns en betydande grad av osäkerhet när det gäller temporala samband. Däremot indikerar våra longitudinella studier ändå att det föreligger valida samband i ett längre tidsperspektiv. Eftersom det i tidigare studier i yngre åldersgrupper föreligger vissa tecken som talar för kausalitet - exempelvis dos-responssamband, replikation av fynden, biologisk rimlighet, mm [21, 31, 251-253] - så framstår det som möjligt att funna associationer åtminstone delvis motsvarar kausalsamband. Emellertid bedöms frågan om tidssambandet så avgörande att vi i föreliggande avhandlingsarbete inte drar några sådana slutsatser.

För att i framtiden värdera om det föreligger kausalitet eller ej i funna samband, så bör man utforma framtida studier med flera mätvågor och tätare tidsintervall så att determinanter för depressivitetens dynamik framträder tydligare. Därtill vore det önskvärt att man i framtiden skulle kunna förfina diagnostik eller mer träffsäkert identifiera relevanta subtyper eller fenotyper än med vår föreliggande operationalisering av SSD (exempelvis genom att studera enskilda 
depressiva symtom istället för hela syndrom, eller genom användningen av specifika transdiagnostiska metoder), vilket skulle kunna öka möjligheterna att mer på detaljnivå studera sambanden. Även om orsakssambanden vid psykisk ohälsa är komplext sammanvävda i nätverk, så ger den vetenskapliga progressen inom forskningsfältet anledning till optimism. 


\section{Slutsatser och framtidsutblickar}

Detta avhandlingsprojekt hade som syfte att öka vår förståelse för den oklara zonen mellan normalt åldrande och syndromal depression, och mer specifikt för SSD hos äldre äldre personer.

Studie 1 och 2 har med olika metodologier beskrivit hur tillvaron med SSD kan te sig för äldre äldre personer, och vilka faktorer som har association till graden av depressivitet $\mathrm{i}$ ett tvärsnittsperspektiv. Studie 1 bidrog till att med naturalistisk öppenhet och intervjuer beskriva och jämföra SSD mot ND och syndromal depression bland äldre äldre personer, och vid latent innehållsanalys identifierades fyra teman som tillsammans ger en allsidig bild av SSD i ålderdomen. I jämförelsen mellan SSD, ND och syndromal depression sågs många likheter mellan samtliga dessa kategorier av depressivitet, medan skillnaderna föreföll större mellan SSD och depression jämfört med SSD och ND, vilket tolkades styrka föreställningen om SSD som något kvalitativt (d.v.s. inte bara kvantitativt) annorlunda från syndromal depression.

Förhoppningsvis kan denna och framtida kompletterande studier bidra till vår ökade förståelse av SSD och därmed indirekt tydliggöra motiv för, och förslag till utformning av potentiella interventioner mot associerade besvär.

Studie 2 bidrog till att kartlägga associerade faktorer till SSD bland äldre äldre personer i ett tvärsnittsperspektiv, och enligt multipel logistisk och linjär regression bekräftades hypoteserna att samtliga fyra domäner - sociodemografiska faktorer, avtagande fysisk funktion, neuropsykiatriska och existentiella faktorer - var signifikant associerade till SSD. En tolkning var att vissa markörer för SSD saknas i etablerade diagnoskriterier för depression, varför det är angeläget med en öppenhet för andra depressiva tecken än de klassiska DSM-kriterierna för att inte förbise signifikant depressivitet i det kliniska arbetet. Genom uppmärksammandet av den individuella berättelsen kan vi således öka precisionen i diagnostik, och möjligen också utforma behandlingsval så att det blir både kausalt träffsäkert på individnivå och personcentrerat med beaktande av den äldre personens preferenser och subjektiva förståelse av sitt tillstånd.

Studie 3 och 4 visade att äldre äldre personer med SSD jämfört med ND är associerat med negativa utfall av bland annat lägre subjektiv hälsoupplevelse, högre sjukvårdskostnader och sjuklighet över lång tid. Totala direkta sjukvårdskostnader per månad överlevnad under fem år var $45 \%$ högre för personer med SSD Ever jämfört med ND Both vilket i överensstämmelse med vår hypotes var signifikant även när vi kontrollerade för somatisk multisjukdom. Tvärtemot våra hypoteser var dock varken kognitiv dysfunktion, kronisk smärta, låg ADL-funktion, eller fysisk funktion signifikant associerade med ökade framtida sjukvårdskostnader i den multivariata regressionen.

I enlighet med uppställda hypoteser var SSD jämfört med ND associerat med både låg P-ADL, låg I-ADL, låg subjektiv hälsa, lägre kognitiv funktion, ökad ensamhet och depressivitet vid de fyra mätvågorna under åtta år. Tvärtemot våra hypoteser var dock kognitiv dysfunktion inte längre signifikant associerad till SSD när man kontrollerade för andra oberoende variabler. 
Tvärtemot våra hypoteser var inte heller dödligheten förhöjd över nio års uppföljning för personer med SSD jämfört med ND, när man kontrollerade för relevanta kovariater.

Eftersom tidigare studier pekat på att SSD är vanligt i samhället - kanske särskilt bland äldre personer - så indikerar dessa studiefynd att SSD bland äldre äldre människor är betydelsefullt för både patienterna, sjukvården och samhället. Även om DSM-systemet inte inkluderar SSD som en egen diagnos för närvarande, så motsvarar tillståndet lidande och funktionspåverkan som skulle kunna motivera interventioner i det enskilda fallet. Sådana interventioner är otillräckligt studerade för denna målgrupp, men mycket talar för att interventioner liknande dem för syndromal depression kan vara tillämpliga även om både diagnostik och behandling behöver anpassas till individen och den äldre äldre personens förutsättningar. Huruvida man bör kalla SSD för sjukdomstillstånd eller normalt åldrande har diskuterats bl a utifrån epidemiologiskt och socialkonstruktionistiskt perspektiv, och en preliminär slutsats från denna diskussion är att SSD inte självklart bör klassas som endera normalitet eller sjukdom. På basen av avhandlingens studieresultat och den studerade litteraturen i ämnesområdet gör jag följande tolkning av SSD hos äldre äldre personer, i enlighet med en biopsykosocial stress-sårbarhetsmodell (Figur 13).

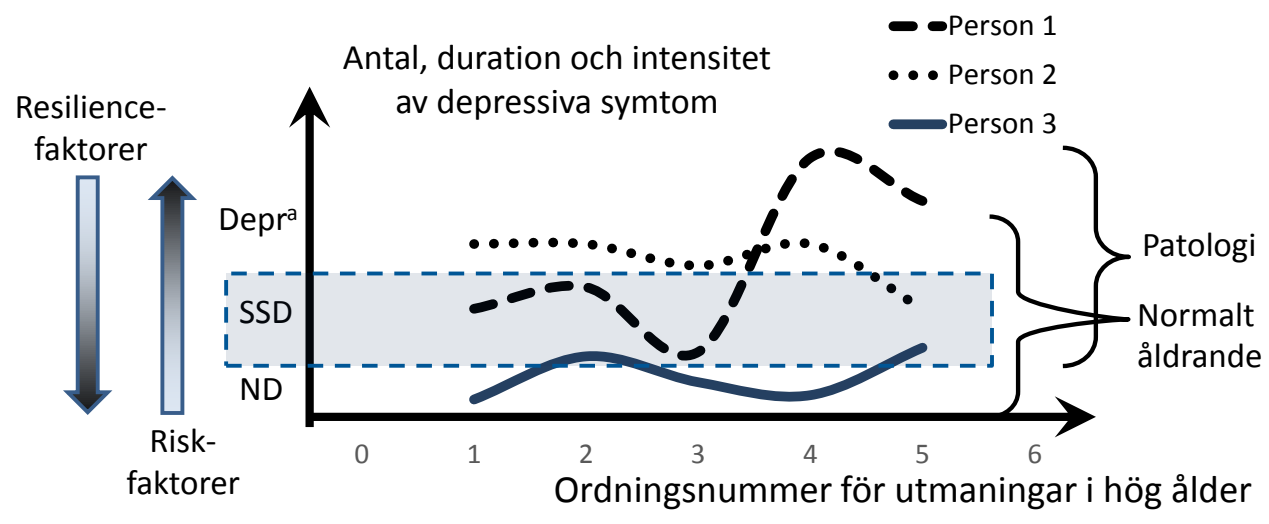

Figur 13. En tolkning av SSD hos äldre äldre personer enligt principerna för den biopsykosociala stress-sårbarhetsmodellen, med inspiration från Aggernæs et al 2017 [254]. Antal, duration och intensitet av depressiva symptom presenteras som funktion av ordningsnummer för utmaningar $i$ åldrandet. Resilience-faktorer minskar sårbarheten hos individen, medan riskfaktorer ökar densamma. Patologi och normalt åldrande har sinsemellan ett överlappande område där SSD ingår. Anmärkning: ${ }^{a}=$ ordet depression har förkortats Depr i figuren.

Hur vi affektivt reagerar på olika typer av utmaningar i åldrandet är ytterst individuellt, varför förändringen (storlek och riktning i diagrammet) av antal, duration eller intensitet av depressiva symptom vid varje utmaning är olika för olika personer. SSD hos en person i en tid kan vara en naturlig del av normalt åldrande, vilket även del av depressionsarean i diagrammet kan vara 
principiellt, och samtidigt kan SSD med depressiva symtom av samma antal, duration och intensitet hos en annan person motsvara patologi. En alternativ formulering bortom gränsdragningar mellan normalt åldrandet och patologi vore att se SSD som en generell sårbarhet, vilken som grundregel kan behandlas.

Olika behandlingar skulle därvid lämpa sig olika väl beroende på genesen till sårbarheten hos den enskilda individen. När existentiella frågor bidrar mest till den ökade sårbarheten som en form av riskfaktorer, så torde samtalsbehandling med inslag av reminiscens, problemlösning eller andra KBT-interventioner kunna vara goda alternativ. När neurokemiska mekanismer som en annan form av riskfaktorer är mer bidragande i genesen torde läkemedelsbehandling vara ett gott alternativ. Genom att värdera och uppmärksamma den äldre individens specifika berättelse skulle således en skräddarsydd intervention (vilket är alltmer omskrivet bl a inom KBT) underlättas, förutom att den diagnostiska bedömningen förbättras. Förutom att kombinationsbehandlingar av olika interventioner ofta framstår lämpliga, så torde salutogena eller resilience-stärkande interventioner i form av exempelvis beteendeaktivering och fysisk aktivitet ha effekter som minskar sårbarhet. Sådan minskad sårbarhet skulle då potentiellt vara associerad (oavsett kausalitet) med högre ADL-funktioner och subjektiv hälsa, minskad depressivitet och lägre direkta samhällskostnader, med mera. Enligt vår tidigare diskussion framstår såväl en steppedcare-modell som Collaborative Care och CGA-modellen som goda alternativ för vård och omsorg, eftersom dessa samtliga tar hänsyn till de vanligen komplexa multifaktoriella sambanden som får en enskild äldre äldre person att uppvisa SSD.

Praktiska implikationer av föreliggande avhandling är att organisationer och personal inom vården och omsorgen skulle behöva ha en ökad vaksamhet och öppenhet inför att SSD eller lindrig depressivitet hos äldre personer kan vara betydelsefullt för både individens hälsa och för samhället. Med en sådan vaksamhet och öppenhet kan exempelvis läkare och andra yrkeskategorier i samarbete - i primärvård och sekundärvård - fånga upp lindriga depressiva besvär och efter en allsidig bedömning överväga om man enligt en stepped-care-modell bör vidta åtgärder. För en korrekt analys av den äldre personens besvärsbild behöver man beakta såväl samsjuklighet och transkulturella aspekter och individens subjektiva uppfattningar, eftersom dessa kan vara avgörande för både diagnostik och behandling. Genom att väga in såväl vetenskapliga evidens med kliniskt kunnande och patientens unika situation och preferenser bör man därefter kunna utforma en individanpassad eller skräddarsydd behandling som förhoppningsvis med större precision kommer att kunna hjälpa den äldre äldre personen till bättre livskvalitet och högre resilience, såväl som en minskad sjuklighet över tid.

Framtida studier skulle kunna öka vår förståelse av möjliga kausala aspekter relationer mellan depressiva symtom och sjuklighet i ålderdomen genom att använda tätare mätintervall och även kontrollera för medierande faktorer som definierats a priori. En mer noggrann analys av enskilda depressiva symtom, eller av transdiagnostiska modeller, skulle också kunna öka möjligheterna att urskilja moderatorer och relevanta fenotyper ur de heterogena tillstånden SSD och depression. Framtida kvalitativa studier skulle kunna fördjupa förståelsen för SSD och på detta sätt utforska 
heterogenitet och homogenitet inom och mellan kategorier av depressivitet, av betydelse för både diagnostik och behandling. Därtill finns ett behov av preventions- och behandlingsstudier för SSD hos äldre äldre personer för att värdera vilka interventioner som skulle kunna reducera sjuklighet, samhällskostnader, och förbättra livskvalitet. 


\section{Tack}

Till min huvudhandledare, docent Anna Milberg, för ditt fantastiska jobb som handledare. Du har uppmuntrat och inspirerat mig, och du har lärt mig det fina hantverket forskning på detaljnivå. Med ihärdighet, konstruktiva frågor och synpunkter, och med mycket beröm har du sporrat mig att läsa, undersöka, skriva och revidera. Det var precis vad jag behövde :-)! Det har varit ett stort nöje att ta del av din stora kompetens inom olika former av forskningsmetod, förutom att jag också mycket uppskattat våra samtal om vardagen, universitets- och sjukvårdsorganisation, familjelivet, och naturupplevelser.

Till min bihandledare, professor Jan Marcusson, för inspiration, för din kreativitet och dina visioner som hjälpt mig att utmana mig själv lite mer, att tro på mig själv, och att tänka lite friare. Du har även varit en inspiration när det gäller frågan om hur man kombinerar forskning, kliniskt arbete, fysisk och mental träning med estetik. Tack för det!

Till forskningsledare och min medförfattare docent Ewa Wressle, som fungerat som en bihandledare fastän du inte varit handledare formellt inom doktorandprojektet. Vilken generositet av dig! Tack för allt förarbete, huvudarbete och efterarbete i ELSA85-projektet, och för din hjälp som vägledare för mig i forskningsvärlden. Tack också för alla morgnar på geriatriska mottagningen, då du varit först på jobbet och satt på kaffebryggaren åt oss andra - underbart!

Till Mats Fredriksson vid Forum Östergötland, Linköping Universitet, som bistått mig många gånger med statistisk rådgivning på ett utvecklande sätt, och till min medförfattare Lars Bernfort för god utbildning och inspirerande och trevligt samarbete i den hälsoekonomiska analysen.

Till alla övriga medarbetare som varit med och samlat in data till ELSA85-projektet, och till alla studiedeltagare som ville delta i projektet och som därmed bidragit till kunskapsutvecklingen, och i förlängningen till en bättre vård, omsorg och ett bättre samhälle.

Till mina forskningskollegor Elisabet Classon, Katarina Fällman, Maria Johansson, Yvonne Johansson, Camilla Nilsberth, Katarina Nägga, Johanna Simmons, Björn Westerlind och Nicolina Wiklund på avdelningen för Geriatrik vid Linköpings universitet för trevligt och givande samarbete vid forskningsseminarier och andra tillställningar.

Till mina chefer som bidragit till denna forskning genom att ge mig tjänstledighet och stöd för forskningen: Marita Ström och Bengt-Olof Bengtsson vid Psykiatriska kliniken, och Kerstin Arbring, Sabina Olin Skoglund, Cilla Dobrov och Anne Ekdahl vid Geriatriska enheten av Universitetssjukhuset i Linköping.

Till min kliniska handledare inom psykiatrin, Jenö Lückl, som varit en klippa för mig när mitt jobb stundtals varit rörigt och splittrat mellan olika engagemang inom psykiatri, geriatrik, forskning, utbildning och psykoterapi. Till min rumskamrat Emil Gustafsson som förgyllt morgnar och eftermiddagar på jobbet genom små roliga betraktelser, skoj och uppmuntran i 
vardagens jobb: livet är en fest! Till alla fina kollegor inom geriatrisk och psykiatrisk sjukvård, vilka gör mitt jobb i vardagen så trevligt varje dag.

Till mina vänner Johan Lindkvist och Ambjörn Furenhed, vilka under många år bjudit mig på jättemånga fina och spännande samtal av nyfikenhet, filosofi, estetik, levnadsvisdom och roliga skämt. Tänk vad härligt att få träffa er regelbundet. Ni har bidragit till denna avhandling på ovanstående sätt, och genom mekanismer som ingen av oss helt kan förstå!

Till mina vänner och läkarkollegor Ted Cabreira och Oskar Lundgren och Mikael Nilsson som hjälpt mig med perspektiv, stöd och utveckling i jobb, fritid och forskning genom åren.

Till mina föräldrar Ulla och Johnny Ludvigsson för all den kärlek och allt stöd som ni givit mig under hela mitt liv. Till mina syskon Jonas, David, Mattias och Johanna - ni är och har varit mina fantastiska följeslagare, var och en av er är inspirerande förebilder för mig på sitt sätt.

Till min älskade Kattis för all kärlek och allt stöd du ger mig, och för alla fina stunder. Du ifrågasätter, och hjälper mig att ta nya steg i min utveckling - på ett uppfriskande, underhållande och härligt sätt. Du hjälper mig att tycka mer om mig själv.

Till mina barn Kajsa och Olle för att ni är er själva, för alla härliga stunder, och för att ni är mina läromästare i livet. Den här avhandlingen har jag skrivit med er kärlek och ert stöd. Tack för den hjälpen! 


\section{Referenser:}

1. Pauser, H., J. Lundmark, and B. Lindgren, Ny geropsykiatrisk vårdmodell möjliggör snabbt omhändertagande av äldre - en femårsrapport. Läkartidningen, 1989. 86(30-31): p. 2600-2603.

2. Horwitz, A.V., J.C. Wakefield, and L. Lorenzo-Luaces, History of depression, in The Oxford handbook of mood disorders R.J. DeRubeis and D.R. Strunk, Editors. 2016, Oxford University Press: New York.

3. Dewhurst, W.G., Melancholia and depression: from hippocratic times to modern times. J. Psychiatry Neurosci, 1992. 17: p. 81-83.

4. Richet, C., An Address ON ANCIENT HUMORISM AND MODERN HUMORISM: Delivered at the International Congress of Physiology held in Vienna, September 27th to 30th. Br Med J, 1910. 2(2596): p. 921-6.

5. von Linné, C., Linnés Systema morborum. Uppsala universitets årsskrift. 1957: Lundequist.

6. Bujalkova, M., S. Straka, and A. Jureckova, Hippocrates' humoral pathology in nowaday's reflections. Bratisl Lek Listy, 2001. 102(10): p. 489-92.

7. World Health Organization, ICD-10 Classification of Mental and Behavioural Disorders (The): Diagnostic Criteria for Research. 1993: World Health Organization.

8. Suris, A., R. Holliday, and C.S. North, The Evolution of the Classification of Psychiatric Disorders. Behav Sci (Basel), 2016. 6(1).

9. Kawa, S. and J. Giordano, A brief historicity of the Diagnostic and Statistical Manual of Mental Disorders: issues and implications for the future of psychiatric canon and practice. Philos Ethics Humanit Med, 2012. 7: p. 2.

10. American Psychiatric Association. Diagnostic and statistical manual of mental disorders : DSM-5. 2013; 5th ed.:[

11. Kendler, K.S., R.A. Munoz, and G. Murphy, The development of the Feighner criteria: a historical perspective. Am J Psychiatry, 2010. 167(2): p. 134-42.

12. Goldstein, J.M., S. Cherkerzian, and J.C. Simpson, Validity: Definitions and Applications to Psychiatric Research, in Textbook of Psychiatric Epidemiology, M.T. Tsuang, M. Tohen, and P.B. Jones, Editors. 2011, John Wiley \& Sons, Ltd.

13. Robins, E. and S.B. Guze, Establishment of diagnostic validity in psychiatric illness: its application to schizophrenia. Am J Psychiatry, 1970. 126(7): p. 983-7.

14. Goldberg, D., Plato versus Aristotle: categorical and dimensional models for common mental disorders. Compr Psychiatry, 2000. 41(2 Suppl 1): p. 8-13.

15. Judd, L.L., Dimensional paradigm of the long-term course of unipolar major depressive disorder. Depress Anxiety, 2012. 29(3): p. 167-71.

16. Forbes, M.K., et al., Beyond comorbidity: Toward a dimensional and hierarchical approach to understanding psychopathology across the life span. Dev Psychopathol, 2016. 28(4pt1): p. 971986.

17. Judd, L.L., et al., Subsyndromal symptomatic depression: a new mood disorder? J Clin Psychiatry, 1994. 55 Suppl: p. 18-28.

18. Sadek, N. and J. Bona, Subsyndromal symptomatic depression: a new concept. Depress Anxiety, 2000. 12(1): p. 30-9.

19. Judd, L.L., H.S. Akiskal, and M.P. Paulus, The role and clinical significance of subsyndromal depressive symptoms (SSD) in unipolar major depressive disorder. J Affect Disord, 1997. 45(1-2): p. 5-17; discussion 17-8.

20. Lyness, J.M., et al., The clinical significance of subsyndromal depression in older primary care patients. Am J Geriatr Psychiatry, 2007. 15(3): p. 214-23. 
21. Meeks, T.W., et al., A tune in "a minor" can "b major": a review of epidemiology, illness course, and public health implications of subthreshold depression in older adults. J Affect Disord, 2011. 129(1-3): p. 126-42.

22. Rodriguez, M.R., et al., Definitions and factors associated with subthreshold depressive conditions: a systematic review. BMC Psychiatry, 2012. 12: p. 181.

23. Cuijpers, P., et al., Differential mortality rates in major and subthreshold depression: metaanalysis of studies that measured both. Br J Psychiatry, 2013. 202(1): p. 22-7.

24. Sheikh, J.A. and J.A. Yeasavage, Geriatric Depression Scale (GDS): recent findings and development of a shorter version., in Clinical Gerontology: A Guide to Assessment and Intervention, T.L. Brink, Editor. 1986, Howarth Press: New York.

25. Chachamovich, E., et al., Impact of major depression and subsyndromal symptoms on quality of life and attitudes toward aging in an international sample of older adults. Gerontologist, 2008. 48(5): p. 593-602.

26. Murphy, J.M., Symptom Scales and Diagnostic Schedules in Adult Psychiatry, in Textbook of Psychiatric Epidemiology, M.T. Tsuang, M. Tohen, and P.B. Jones, Editors. 2011, John Wiley \& Sons, Ltd.

27. Cross, S.P. and I. Hickie, Transdiagnostic stepped care in mental health. Public Health Res Pract, 2017. 27(2).

28. Gordis, L., Epidemiology. 2014, Elsevier/Saunders: Philadelphia, PA p. 21-22.

29. Insel, T.R., Translating scientific opportunity into public health impact: a strategic plan for research on mental illness. Arch Gen Psychiatry, 2009. 66(2): p. 128-33.

30. Schwartz, L.M. and S. Woloshin, Changing disease definitions: implications for disease prevalence. Analysis of the Third National Health and Nutrition Examination Survey, 1988-1994. Eff Clin Pract, 1999. 2(2): p. 76-85.

31. Ayuso-Mateos, J.L., et al., From depressive symptoms to depressive disorders: the relevance of thresholds. Br J Psychiatry, 2010. 196(5): p. 365-71.

32. Braam, A.W., et al., Depression, subthreshold depression and comorbid anxiety symptoms in older Europeans: results from the EURODEP concerted action. J Affect Disord, 2014. 155: p. 26672.

33. Forsell, Y., A three-year follow-up of major depression, dysthymia, minor depression and subsyndromal depression: results from a population-based study. Depress Anxiety, 2007. 24(1): p. 62-5.

34. Beck, A., et al., Severity of depression and magnitude of productivity loss. Ann Fam Med, 2011. 9(4): p. 305-11.

35. Beekman, A.T., et al., The natural history of late-life depression: a 6-year prospective study in the community. Arch Gen Psychiatry, 2002. 59(7): p. 605-11.

36. Han, L., et al., 12-month cognitive outcomes of major and minor depression in older medical patients. Am J Geriatr Psychiatry, 2008. 16(9): p. 742-51.

37. Laborde-Lahoz, P., et al., Subsyndromal depression among older adults in the USA: prevalence, comorbidity, and risk for new-onset psychiatric disorders in late life. Int I Geriatr Psychiatry, 2014.

38. Glassock, R., A. Denic, and A.D. Rule, When kidneys get old: an essay on nephro-geriatrics. J Bras Nefrol, 2017. 39(1): p. 59-64.

39. Keller, J.N., Age-related neuropathology, cognitive decline, and Alzheimer's disease. Ageing Res Rev, 2006. 5(1): p. 1-13.

40. Salthouse, T.A., Neuroanatomical substrates of age-related cognitive decline. Psychol Bull, 2011. 137(5): p. 753-84.

41. Pink, A., et al., Cortical Thickness and Depressive Symptoms in Cognitively Normal Individuals: The Mayo Clinic Study of Aging. J Alzheimers Dis, 2017. 58(4): p. 1273-1281. 
42. Mather, M., The Affective Neuroscience of Aging. Annu Rev Psychol, 2016. 67: p. 213-38.

43. Bewernick, B.H. and T.E. Schlaepfer, Chronic depression as a model disease for cerebral aging. Dialogues Clin Neurosci, 2013. 15(1): p. 77-85.

44. Skoog, I., Bridge Over Troubled Water. Am J Geriatr Psychiatry, 2017. 25(4): p. 340-341.

45. Almeida, D.M., et al., The speedometer of life: Stress, health and aging. , in Handbook of the psychology of aging, K.W. Schaie and S.L. Willis, Editors. 2011, Elsevier Academic Press: San Diego, CA, US. p. pp. 191-206.

46. Blanchflower, D.G. and A.J. Oswald, Is well-being U-shaped over the life cycle? Soc Sci Med, 2008. 66(8): p. 1733-49.

47. Statistics", O.f.N. Measuring National Well-being : At what age is Personal Well-being the highest? 2016 [cited 2018 May 18th].

48. Kunzmann, U., T.D. Little, and J. Smith, Is age-related stability of subjective well-being a paradox? Cross-sectional and longitudinal evidence from the Berlin Aging Study. Psychol Aging, 2000. 15(3): p. 511-26.

49. Ouwehand, C., D.T. de Ridder, and J.M. Bensing, A review of successful aging models: proposing proactive coping as an important additional strategy. Clin Psychol Rev, 2007. 27(8): p. 873-84.

50. Nygren, B., et al., Resilience, sense of coherence, purpose in life and self-transcendence in relation to perceived physical and mental health among the oldest old. Aging Ment Health, 2005. 9(4): p. 354-62.

51. Charles, S.T. and L.L. Carstensen, Social and emotional aging. Annu Rev Psychol, 2010. 61: p. 383409.

52. Allen, A.B. and M.R. Leary, Self-Compassion, Stress, and Coping. Soc Personal Psychol Compass, 2010. 4(2): p. 107-118.

53. Audulv, A., et al., Coping, adapting or self-managing - what is the difference? A concept review based on the neurological literature. J Adv Nurs, 2016. 72(11): p. 2629-2643.

54. Bjorklof, G.H., et al., Coping and depression in old age: a literature review. Dement Geriatr Cogn Disord, 2013. 35(3-4): p. 121-54.

55. Atkinson, P.A., C.R. Martin, and J. Rankin, Resilience revisited. J Psychiatr Ment Health Nurs, 2009. 16(2): p. 137-45.

56. Tusaie, K. and J. Dyer, Resilience: a historical review of the construct. Holist Nurs Pract, 2004. 18(1): p. 3-8; quiz 9-10.

57. MacLeod, S., et al., The impact of resilience among older adults. Geriatr Nurs, 2016. 37(4): p. 26672.

58. Shen, $\mathrm{K}$. and Y. Zeng, The association between resilience and survival among Chinese elderly. Demogr Res, 2010. 23(5): p. 105-116.

59. Hayman, K.J., N. Kerse, and N.S. Consedine, Resilience in context: the special case of advanced age. Aging Ment Health, 2017. 21(6): p. 577-585.

60. Lundman, B., et al., Inner strength--a theoretical analysis of salutogenic concepts. Int J Nurs Stud, 2010. 47(2): p. 251-60.

61. Eriksson, M. and B. Lindstrom, Validity of Antonovsky's sense of coherence scale: a systematic review. J Epidemiol Community Health, 2005. 59(6): p. 460-6.

62. Wadensten, B., An analysis of psychosocial theories of ageing and their relevance to practical gerontological nursing in Sweden. Scand J Caring Sci, 2006. 20(3): p. 347-54.

63. Bowling, A., Aspirations for older age in the 21st century: what is successful aging? Int J Aging Hum Dev, 2007. 64(3): p. 263-97.

64. Wadensten, B., Introducing older people to the theory of gerotranscendence. J Adv Nurs, 2005. 52(4): p. 381-8. 
65. Vahia, I.V., et al., Developing a dimensional model for successful cognitive and emotional aging. Int Psychogeriatr, 2012. 24(4): p. 515-23.

66. Cosco, T.D., et al., Operational definitions of successful aging: a systematic review. Int Psychogeriatr, 2014. 26(3): p. 373-81.

67. Rowe, J.W. and R.L. Kahn, Successful aging. Gerontologist, 1997. 37(4): p. 433-40.

68. Carver, L.F. and D. Buchanan, Successful aging: considering non-biomedical constructs. Clin Interv Aging, 2016. 11: p. 1623-1630.

69. Charles, S.T., Strength and vulnerability integration: a model of emotional well-being across adulthood. Psychol Bull, 2010. 136(6): p. 1068-91.

70. Hinck, S., The lived experience of oldest-old rural adults. Qual Health Res, 2004. 14(6): p. 779-91.

71. Sjoberg, L., et al., Secular changes in the relation between social factors and depression: a study of two birth cohorts of Swedish septuagenarians followed for 5 years. J Affect Disord, 2013. 150(2): p. 245-52.

72. Christensen, K., et al., Ageing populations: the challenges ahead. Lancet, 2009. 374(9696): p. 1196-208.

73. Falk, H., et al., Functional disability and ability 75-year-olds: a comparison of two Swedish cohorts born 30 years apart. Age Ageing, 2014. 43(5): p. 636-41.

74. NIH, N.I.o.A., Why Population Aging Matters: A Global Perspective. 2007: National Institute on Aging, National Institutes of Health, U.S. Department of Health and Human Services. United States. .

75. Collerton, J., et al., Health and disease in 85 year olds: baseline findings from the Newcastle 85+ cohort study. BMJ, 2009. 339: p. b4904.

76. Baltes, P.B. and J. Smith, New frontiers in the future of aging: from successful aging of the young old to the dilemmas of the fourth age. Gerontology, 2003. 49(2): p. 123-35.

77. Mathers, C.D. and D. Loncar, Projections of global mortality and burden of disease from 2002 to 2030. PLoS Med, 2006. 3(11): p. e442.

78. Global Burden of Disease Study, C., Global, regional, and national incidence, prevalence, and years lived with disability for 301 acute and chronic diseases and injuries in 188 countries, 19902013: a systematic analysis for the Global Burden of Disease Study 2013. Lancet, 2015. 386(9995): p. 743-800.

79. IsHak, W.W., et al., Quality of life: the ultimate outcome measure of interventions in major depressive disorder. Harv Rev Psychiatry, 2011. 19(5): p. 229-39.

80. Cassano, P. and M. Fava, Depression and public health: an overview. J Psychosom Res, 2002. 53(4): p. 849-57.

81. Socialstyrelsen, Nationella riktlinjer för vård vid depression och ångestsyndrom - Stöd för styrning och ledning: 2017-12-4. 2017: Socialstyrelsen.

82. (NICE)", T.N.I.f.H.a.C.E. Depression in adults: recognition and management. Clinical guideline [CG90]. 2009 April 2018 13th of May, 2018].

83. Beekman, A.T., J.R. Copeland, and M.J. Prince, Review of community prevalence of depression in later life. Br J Psychiatry, 1999. 174: p. 307-11.

84. Steel, Z., et al., The global prevalence of common mental disorders: a systematic review and meta-analysis 1980-2013. Int J Epidemiol, 2014. 43(2): p. 476-93.

85. Ferrari, A.J., et al., Global variation in the prevalence and incidence of major depressive disorder: a systematic review of the epidemiological literature. Psychol Med, 2013. 43(3): p. 471-81.

86. Sjoberg, L., et al., Prevalence of depression: Comparisons of different depression definitions in population-based samples of older adults. J Affect Disord, 2017. 221: p. 123-131.

87. Skoog, I., Psychiatric disorders in the elderly. Can J Psychiatry, 2011. 56(7): p. 387-97. 
88. Fiske, A., J.L. Wetherell, and M. Gatz, Depression in older adults. Annu Rev Clin Psychol, 2009. 5: p. 363-89.

89. Haigh, E.A.P., et al., Depression Among Older Adults: A 20-Year Update on Five Common Myths and Misconceptions. Am J Geriatr Psychiatry, 2018. 26(1): p. 107-122.

90. Bergdahl, E., et al., Depression among the oldest old: the Umea 85+ study. Int Psychogeriatr, 2005. 17(4): p. 557-75.

91. Sigstrom, R., et al., Depressive spectrum states in a population-based cohort of 70-year olds followed over 9 years. Int J Geriatr Psychiatry, 2018.

92. Tsopelas, $\mathrm{C}$., et al., Neuropathological correlates of late-life depression in older people. $\mathrm{Br} \mathrm{J}$ Psychiatry, 2011. 198(2): p. 109-14.

93. Tadayonnejad, R. and O. Ajilore, Brain network dysfunction in late-life depression: a literature review. J Geriatr Psychiatry Neurol, 2014. 27(1): p. 5-12.

94. Alexopoulos, G.S., Depression in the elderly. Lancet, 2005. 365(9475): p. 1961-70.

95. Lebedeva, A., et al., Structural brain changes associated with depressive symptoms in the elderly with Alzheimer's disease. J Neurol Neurosurg Psychiatry, 2014. 85(8): p. 930-5.

96. Gothe, F., et al., Cerebrovascular diseases and depression: epidemiology, mechanisms and treatment. Panminerva Med, 2012. 54(3): p. 161-70.

97. Gulmann, N.C., Depressionssjukdomar och andra förstämningssyndrom, in Gerontopsykiatri, N.C. Gulmann, Editor. 2003, Studentlitteratur: Lund. p. 134-151.

98. Amore, M., et al., Beyond nosography of depression in elderly. Arch Gerontol Geriatr, 2007. 44 Suppl 1: p. 13-22.

99. Mehta, M., et al., Depressive symptoms in late life: associations with apathy, resilience and disability vary between young-old and old-old. Int J Geriatr Psychiatry, 2008. 23(3): p. 238-43.

100. Pantzar, A., et al., Cognitive deficits in unipolar old-age depression: a population-based study. Psychol Med, 2014. 44(5): p. 937-47.

101. Lapierre, S., et al., A systematic review of elderly suicide prevention programs. Crisis, 2011. 32(2): p. 88-98.

102. Alexopoulos, G.S., et al., Assessment of late life depression. Biol Psychiatry, 2002. 52(3): p. 16474.

103. Herrmann, L.L., G.M. Goodwin, and K.P. Ebmeier, The cognitive neuropsychology of depression in the elderly. Psychol Med, 2007. 37(12): p. 1693-702.

104. Sachs-Ericsson, N., et al., A longitudinal study of differences in late- and early-onset geriatric depression: depressive symptoms and psychosocial, cognitive, and neurological functioning. Aging Ment Health, 2013. 17(1): p. 1-11.

105. Hegeman, J.M., et al., Phenomenology of depression in older compared with younger adults: meta-analysis. Br J Psychiatry, 2012. 200(4): p. 275-81.

106. Barbui, C., et al., Efficacy of antidepressants and benzodiazepines in minor depression: systematic review and meta-analysis. Br J Psychiatry, 2011. 198(1): p. 11-6, sup 1.

107. Cuijpers, P., et al., Psychotherapy for subclinical depression: meta-analysis. Br J Psychiatry, 2014. 205(4): p. 268-74.

108. Cherubini, A., et al., Subthreshold depression in older subjects: an unmet therapeutic need. J Nutr Health Aging, 2012. 16(10): p. 909-13.

109. Kok, R.M. and C.F. Reynolds, 3rd, Management of Depression in Older Adults: A Review. JAMA, 2017. 317(20): p. 2114-2122.

110. Gilbody, S., et al., Effect of Collaborative Care vs Usual Care on Depressive Symptoms in Older Adults With Subthreshold Depression: The CASPER Randomized Clinical Trial. JAMA, 2017. 317(7): p. 728-737. 
111. Socialstyrelsen, Personligt ombud för personer med psykiska funktionshinder - En sexårsuppföljning av tio försöksverksamheter 2004.

112. Thota, A.B., et al., Collaborative care to improve the management of depressive disorders: a community guide systematic review and meta-analysis. Am J Prev Med, 2012. 42(5): p. 525-38.

113. Grochtdreis, T., et al., Cost-effectiveness of collaborative care for the treatment of depressive disorders in primary care: a systematic review. PLoS One, 2015. 10(5): p. e0123078.

114. Ellis, G., et al., Comprehensive geriatric assessment for older adults admitted to hospital. Cochrane Database Syst Rev, 2017. 9: p. CD006211.

115. Ekerstad, N., et al., Is the acute care of frail elderly patients in a comprehensive geriatric assessment unit superior to conventional acute medical care? Clin Interv Aging, 2017. 12: p. 1-9.

116. Blazer, D.G., Psychiatry and the oldest old. Am J Psychiatry, 2000. 157(12): p. 1915-24.

117. Van't Veer-Tazelaar, P., et al., Cost-effectiveness of a stepped care intervention to prevent depression and anxiety in late life: randomised trial. Br J Psychiatry, 2010. 196(4): p. 319-25.

118. Silfvernagel, K., et al., Individually tailored internet-based cognitive behaviour therapy for older adults with anxiety and depression: a randomised controlled trial. Cogn Behav Ther, 2017: p. 115.

119. Beyer, J.L. and K.G. Johnson, Advances in Pharmacotherapy of Late-Life Depression. Curr Psychiatry Rep, 2018. 20(5): p. 34.

120. Kukreja, S., et al., Polypharmacy in psychiatry: a review. Mens Sana Monogr, 2013. 11(1): p. 8299.

121. Sadavoy, J., An integrated model for defining the scope of psychogeriatrics: the five Cs. Int Psychogeriatr, 2009. 21(5): p. 805-12.

122. Karlsson, I., Depressiv sjukdom vid åldrandet. Äldrepsykiatri -Kliniska riktlinjer för utredning och behandling, ed. K. Sparring Björkstén. 2013: Svenska Psykiatriska Föreningen (SPF) och Gothia Fortbildning $A B$.

123. Steffens, D.C. and D.G. Blazer, Mood Disorders, in Essentials of Geriatric Psychiatry, D.G. Blazer and D.C. Steffens, Editors. 2012, American Psychiatric Publishing.

124. Parker, G., et al., Defining melancholia: A core mood disorder. Bipolar Disord, 2017. 19(3): p. 235237.

125. Kydd, A. and A. Fleming, What doctors need to know: Prescribing or not for the oldest old. Maturitas, 2016. 90: p. 9-16.

126. Maj, M., When does depression become a mental disorder? Br J Psychiatry, 2011. 199(2): p. 85-6.

127. Wakefield, J.C., False positives in psychiatric diagnosis: implications for human freedom. Theor Med Bioeth, 2010. 31(1): p. 5-17.

128. Heok, K.E. and R. Ho, The many faces of geriatric depression. Curr Opin Psychiatry, 2008. 21(6): p. 540-5.

129. Pepersack, T., et al., Correlates of unrecognized depression among hospitalized geriatric patients. J Psychiatr Pract, 2006. 12(3): p. 160-7.

130. Hedberg, P., et al., Purpose in life over a five-year period: a longitudinal study in a very old population. Int Psychogeriatr, 2011. 23(5): p. 806-13.

131. Katon, W.J., et al., Increased medical costs of a population-based sample of depressed elderly patients. Arch Gen Psychiatry, 2003. 60(9): p. 897-903.

132. Unutzer, J., et al., Depressive symptoms and the cost of health services in HMO patients aged 65 years and older. A 4-year prospective study. JAMA, 1997. 277(20): p. 1618-23.

133. Leibson, C.L., et al., Direct medical costs and source of cost differences across the spectrum of cognitive decline: a population-based study. Alzheimers Dement, 2015. 11(8): p. 917-32.

134. Reuben, D.B., et al., The effect of self-reported and performance-based functional impairment on future hospital costs of community-dwelling older persons. Gerontologist, 2004. 44(3): p. 401-7. 
135. Lazkani, A., et al., Healthcare costs associated with elderly chronic pain patients in primary care. Eur J Clin Pharmacol, 2015. 71(8): p. 939-47.

136. Pitkala, K.H., et al., Effects of psychosocial group rehabilitation on health, use of health care services, and mortality of older persons suffering from loneliness: a randomized, controlled trial. J Gerontol A Biol Sci Med Sci, 2009. 64(7): p. 792-800.

137. Hajek, A., et al., Disentangling the complex relation of disability and depressive symptoms in old age - findings of a multicenter prospective cohort study in Germany. Int Psychogeriatr, 2017. 29(6): p. 885-895.

138. Callahan, C.M., et al., Longitudinal study of depression and health services use among elderly primary care patients. J Am Geriatr Soc, 1994. 42(8): p. 833-8.

139. Houtjes, W., et al., The impact of an unfavorable depression course on network size and loneliness in older people: a longitudinal study in the community. Int J Geriatr Psychiatry, 2014. 29(10): p. 1010-7.

140. Nagga, K., et al., Health-related factors associated with hospitalization for old people: comparisons of elderly aged 85 in a population cohort study. Arch Gerontol Geriatr, 2012. 54(2): p. 391-7.

141. EuroQol, G., EuroQol--a new facility for the measurement of health-related quality of life. Health Policy, 1990. 16(3): p. 199-208.

142. Grimby, G., et al., Dependence and perceived difficulty in daily activities in community-living stroke survivors 2 years after stroke: a study of instrumental structures. Stroke, 1998. 29(9): p. 1843-9.

143. Folstein, M.F., S.E. Folstein, and P.R. McHugh, "Mini-mental state". A practical method for grading the cognitive state of patients for the clinician. J Psychiatr Res, 1975. 12(3): p. 189-98.

144. Regard, M., Cognitive rigidity and flexibility: A neuropsychological study. 1981, University of Victoria. p. PhD. Dissertation.

145. Reitan, R.M., Trail Making Test: manual for administration and scoring. 1992, Tucson, AZ: Reitan Neuropsychology Laboratory.

146. Nordlund, A., et al., The Goteborg MCl study: mild cognitive impairment is a heterogeneous condition. J Neurol Neurosurg Psychiatry, 2005. 76(11): p. 1485-90.

147. de Craen, A.J., T.J. Heeren, and J. Gussekloo, Accuracy of the 15-item geriatric depression scale (GDS-15) in a community sample of the oldest old. Int J Geriatr Psychiatry, 2003. 18(1): p. 63-6.

148. Pocklington, C., et al., The diagnostic accuracy of brief versions of the Geriatric Depression Scale: a systematic review and meta-analysis. Int J Geriatr Psychiatry, 2016. 31(8): p. 837-57.

149. Stek, M.L., et al., Natural history of depression in the oldest old: population-based prospective study. Br J Psychiatry, 2006. 188: p. 65-9.

150. Yesavage, J.A., et al., Development and validation of a geriatric depression screening scale: a preliminary report. J Psychiatr Res, 1982. 17(1): p. 37-49.

151. Montorio, I. and M. Izal, The Geriatric Depression Scale: a review of its development and utility. Int Psychogeriatr, 1996. 8(1): p. 103-12.

152. Rabin, R. and F. de Charro, EQ-5D: a measure of health status from the EuroQol Group. Ann Med, 2001. 33(5): p. 337-43.

153. Fortin, M., et al., A systematic review of prevalence studies on multimorbidity: toward a more uniform methodology. Ann Fam Med, 2012. 10(2): p. 142-51.

154. Iverson, G.L., Interpretation of Mini-Mental State Examination scores in community-dwelling elderly and geriatric neuropsychiatry patients. Int J Geriatr Psychiatry, 1998. 13(10): p. 661-6.

155. Park, N.S., et al., The mediating role of loneliness in the relation between social engagement and depressive symptoms among older Korean Americans: do men and women differ? J Gerontol B Psychol Sci Soc Sci, 2013. 68(2): p. 193-201. 
156. Wirehn, A.B., H.M. Karlsson, and J.M. Carstensen, Estimating disease prevalence using a population-based administrative healthcare database. Scand J Public Health, 2007. 35(4): p. 42431.

157. Patton, M.Q., Qualitative Research \& Evaluation Methods. Third ed. 2002, Thousand Oaks: SAGE Publications Inc

158. Graneheim, U.H. and B. Lundman, Qualitative content analysis in nursing research: concepts, procedures and measures to achieve trustworthiness. Nurse Educ Today, 2004. 24(2): p. 105-12.

159. Gahleitner, S.B., Zwischen Differenz und Dekonstruktion. Methodische Überlegungen zur Überschreitung des biploraren Geschlechterdualismus in der enderforschung nach einem Verfahren von Hagemann-White [Between difference and deconstruction. Thinking about methodological strategies for overcoming bipolar gender dualism in gender research using a method proposed by Hagemann-White]. in Gender methodologisch. Empirische Forschung in der Informationsgesellschaft vor neuen Herausforderungen, S. Buchen, C. Helfferich, and M.S. Maier, Editors. 2004, VS Verlag für Sozialwissenschaften: Wiesbaden. p. pp. 283-292.

160. Gildemeister, R., Gender Studies, in A Companion to Qualitative Research, U. Flick, E. von Kardoff, and I. Steinke, Editors. 2004, SAGE Publications: London. p. 126-127.

161. Graneheim, U.H., B.M. Lindgren, and B. Lundman, Methodological challenges in qualitative content analysis: A discussion paper. Nurse Educ Today, 2017. 56: p. 29-34.

162. Wirehn, A.B., et al., Age-specific direct healthcare costs attributable to diabetes in a Swedish population: a register-based analysis. Diabet Med, 2008. 25(6): p. 732-7.

163. EUnetHTA, E.N.f.H.t.A., EUnetHTA JA 2 WP7. Methods for health economic evaluations - $A$ guideline based on current practices in Europe. Guideline. 2015.

164. Akobundu, E., et al., Cost-of-illness studies : a review of current methods. Pharmacoeconomics, 2006. 24(9): p. 869-90.

165. Benjamini, Y., Discovering the false discovery rate. Journal of the Royal Statistical Society: Series B (Statistical Methodology) 2010. 72(4): p. 405-416.

166. Newman, A.B., An overview of the design, implementation, and analyses of longitudinal studies on aging. J Am Geriatr Soc, 2010. 58 Suppl 2: p. S287-91.

167. Graham, J.W., Missing data analysis: making it work in the real world. Annu Rev Psychol, 2009. 60: p. 549-76.

168. World Medical, A., World Medical Association Declaration of Helsinki: ethical principles for medical research involving human subjects. JAMA, 2013. 310(20): p. 2191-4.

169. Gupta, U.C. and S. Kharawala, Informed consent in psychiatry clinical research: A conceptual review of issues, challenges, and recommendations. Perspect Clin Res, 2012. 3(1): p. 8-15.

170. Roberts, L.W. and B. Roberts, Psychiatric research ethics: an overview of evolving guidelines and current ethical dilemmas in the study of mental illness. Biol Psychiatry, 1999. 46(8): p. 1025-38.

171. Wittink, M.N., et al., How older adults combine medical and experiential notions of depression. Qual Health Res, 2008. 18(9): p. 1174-83.

172. Barg, F.K., et al., A mixed-methods approach to understanding loneliness and depression in older adults. J Gerontol B Psychol Sci Soc Sci, 2006. 61(6): p. S329-39.

173. Switzer, J.F., et al., "Pull yourself up by your bootstraps": a response to depression in older adults. Qual Health Res, 2006. 16(9): p. 1207-16.

174. Allan, J. and A. Dixon, Older women's experiences of depression: a hermeneutic phenomenological study. J Psychiatr Ment Health Nurs, 2009. 16(10): p. 865-73.

175. Fischer, R.S., A. Norberg, and B. Lundman, Embracing opposites: meanings of growing old as narrated by people aged 85. Int J Aging Hum Dev, 2008. 67(3): p. 259-71.

176. Wiberg, P., et al., Secular trends in the prevalence of dementia and depression in Swedish septuagenarians 1976-2006. Psychol Med, 2013. 43(12): p. 2627-34. 
177. McCormack, B., Person-centredness in gerontological nursing: an overview of the literature. J Clin Nurs, 2004. 13(3a): p. 31-8.

178. Geiselmann, B. and M. Bauer, Subthreshold depression in the elderly: qualitative or quantitative distinction? Compr Psychiatry, 2000. 41(2 Suppl 1): p. 32-8.

179. Lee, C.T., et al., Latent class-derived subgroups of depressive symptoms in a community sample of older adults: the Cache County Study. Int J Geriatr Psychiatry, 2012. 27(10): p. 1061-9.

180. van Loo, H.M., et al., Data-driven subtypes of major depressive disorder: a systematic review. BMC Med, 2012. 10: p. 156.

181. Fried, E.I. and R.M. Nesse, Depression is not a consistent syndrome: An investigation of unique symptom patterns in the STAR*D study. J Affect Disord, 2015. 172: p. 96-102.

182. Carragher, N., et al., Subtypes of depression in a nationally representative sample. J Affect Disord, 2009. 113(1-2): p. 88-99.

183. Trivedi, M.H., et al., The Inventory of Depressive Symptomatology, Clinician Rating (IDS-C) and Self-Report (IDS-SR), and the Quick Inventory of Depressive Symptomatology, Clinician Rating (QIDS-C) and Self-Report (QIDS-SR) in public sector patients with mood disorders: a psychometric evaluation. Psychol Med, 2004. 34(1): p. 73-82.

184. Wakefield, J.C. and M.F. Schmitz, Severity of complicated versus uncomplicated subthreshold depression: New evidence on the "Monotonicity Thesis" from the national comorbidity survey. J Affect Disord, 2017. 212: p. 101-109.

185. Piver, A., L.N. Yatham, and R.W. Lam, Bipolar spectrum disorders. New perspectives. Can Fam Physician, 2002. 48: p. 896-904.

186. Kalk, N.J. and A.H. Young, Footnotes to Kraepelin: changes in the classification of mood disorders with DSM-5. BJPsych Open, 2017. 3(3): p. e1-e3.

187. Adams, K.B., Depressive symptoms, depletion, or developmental change? Withdrawal, apathy, and lack of vigor in the Geriatric Depression Scale. Gerontologist, 2001. 41(6): p. 768-77.

188. Ballenger, J.C., et al., Consensus statement on transcultural issues in depression and anxiety from the International Consensus Group on Depression and Anxiety. J Clin Psychiatry, 2001. 62 Suppl 13: p. 47-55.

189. Statistics Sweden. The Total Population Register. Sweden: Statistics Sweden (Statistiska Centralbyrån, SCB) . 2015 [cited 2016.

190. Sveriges Kommuner och Landsting, Ekonomirapporten, maj 2017. Om kommunernas och landstingens ekonomi 2017.

191. Luppa, M., et al., Direct costs associated with depressive symptoms in late life: a 4.5-year prospective study. Int Psychogeriatr, 2013. 25(2): p. 292-302.

192. Bock, J.O., et al., Excess health care costs of late-life depression - Results of the AgeMooDe study. J Affect Disord, 2016. 199: p. 139-47.

193. Bock, J.O., et al., The Impact of Depressive Symptoms on Healthcare Costs in Late Life: Longitudinal Findings From the AgeMooDe Study. Am J Geriatr Psychiatry, 2017. 25(2): p. 131141.

194. Donohue, J.M. and H.A. Pincus, Reducing the societal burden of depression: a review of economic costs, quality of care and effects of treatment. Pharmacoeconomics, 2007. 25(1): p. 7-24.

195. Luppa, M., et al., Cost-of-illness studies of depression: a systematic review. J Affect Disord, 2007. 98(1-2): p. 29-43.

196. Byers, A.L., P.A. Arean, and K. Yaffe, Low use of mental health services among older Americans with mood and anxiety disorders. Psychiatr Serv, 2012. 63(1): p. 66-72.

197. Sussman, T., et al., Improving the management of late-life depression in primary care: barriers and facilitators. Depress Res Treat, 2011. 2011: p. 326307. 
198. Tarricone, R., Cost-of-illness analysis. What room in health economics? Health Policy, 2006. 77(1): p. 51-63.

199. Luppa, M., et al., Healthcare costs associated with recognized and unrecognized depression in old age. Int Psychogeriatr, 2008. 20(6): p. 1219-29.

200. Cepoiu, M., et al., Recognition of depression in older medical inpatients. J Gen Intern Med, 2007. 22(5): p. 559-64.

201. Wittayanukorn, S., J. Qian, and R.A. Hansen, Prevalence of depressive symptoms and predictors of treatment among U.S. adults from 2005 to 2010. Gen Hosp Psychiatry, 2014. 36(3): p. 330-6.

202. Anell, A., A. Glenngård, and S. Merkur, Sweden: Health system review. Health Systems in Transition. 2012.

203. Socialstyrelsen, Elderly need of mental health care and support (Äldres behov av psykiatrisk vård och stöd). 2012-2-22. 2012.

204. Hoeft, T.J., et al., Directions for Effectiveness Research to Improve Health Services for Late-Life Depression in the United States. Am J Geriatr Psychiatry, 2016. 24(1): p. 18-30.

205. Barry, L.C., et al., Longitudinal association between depressive symptoms and disability burden among older persons. J Gerontol A Biol Sci Med Sci, 2009. 64(12): p. 1325-32.

206. Holwerda, T.J., et al., Impact of loneliness and depression on mortality: results from the Longitudinal Ageing Study Amsterdam. Br J Psychiatry, 2016. 209(2): p. 127-34.

207. Stek, M.L., et al., Is depression in old age fatal only when people feel lonely? Am J Psychiatry, 2005. 162(1): p. 178-80.

208. Rapp, M.A., et al., Depression predicts mortality in the young old, but not in the oldest old: results from the Berlin Aging Study. Am J Geriatr Psychiatry, 2008. 16(10): p. 844-52.

209. Blazer, D.G., C.F. Hybels, and C.F. Pieper, The association of depression and mortality in elderly persons: a case for multiple, independent pathways. J Gerontol A Biol Sci Med Sci, 2001. 56(8): p. M505-9.

210. Walker, E.R., R.E. McGee, and B.G. Druss, Mortality in mental disorders and global disease burden implications: a systematic review and meta-analysis. JAMA Psychiatry, 2015. 72(4): p. 334-41.

211. Hill, A.B., The Environment and Disease: Association or Causation? Proc R Soc Med, 1965. 58: p. 295-300.

212. Lewis, G., Introduction to Epidemiologic Research Methods, in Textbook of Psychiatric Epidemiology, M. Tsuang, M. Tohen, and P.B. Jones, Editors. 2011. p. 6.

213. Bresnahan, M., et al., Peering into the Future of Psychiatric Epidemiology, in Textbook of Psychiatric Epidemiology, M.T. Tsuang, M. Tohen, and P.B. Jones, Editors. 2011.

214. Ventriglio, A., A. Bellomo, and D. Bhugra, Web of causation and its implications for epidemiological research. Int J Soc Psychiatry, 2016. 62(1): p. 3-4.

215. March, D. and E. Susser, The eco- in eco-epidemiology. Int J Epidemiol, 2006. 35(6): p. 1379-83.

216. Ormel, J., et al., Temporal and reciprocal relationship between IADL/ADL disability and depressive symptoms in late life. J Gerontol B Psychol Sci Soc Sci, 2002. 57(4): p. P338-47.

217. Koenig, A.M., et al., Neuropsychological functioning in the acute and remitted States of late-life depression. J Alzheimers Dis, 2015. 45(1): p. 175-85.

218. Chen, C.M., et al., The longitudinal relationship between depressive symptoms and disability for older adults: a population-based study. J Gerontol A Biol Sci Med Sci, 2012. 67(10): p. 1059-67.

219. Fishleder, S., et al., Trajectories of depressive symptoms in community-dwelling older adults: $A$ six-month longitudinal study with monthly assessment. J Affect Disord, 2016. 198: p. 171-7.

220. Gorwood, P., et al., Toxic effects of depression on brain function: impairment of delayed recall and the cumulative length of depressive disorder in a large sample of depressed outpatients. Am J Psychiatry, 2008. 165(6): p. 731-9. 
221. Malykhin, N.V. and N.J. Coupland, Hippocampal neuroplasticity in major depressive disorder. Neuroscience, 2015. 309: p. 200-13.

222. McIntyre, R.S., D. Cha, and J.K. Soczynska, Cognition in Major Depressive Disorder. Oxford Psychiatry Library. 2014: Oxford University Press.

223. Judd, L., Schettler, P.J., Akiskal, H.S., The prevalence, clinical relevance, and public health significance of subthreshold depressions. The Psychiatric Clinics Of North America 2002. 25(4): p. 685-98.

224. Wakefield, J.C., The concept of mental disorder. On the boundary between biological facts and social values. Am Psychol, 1992. 47(3): p. 373-88.

225. Hayes, J. and E.L. Hannold, The road to empowerment: a historical perspective on the medicalization of disability. J Health Hum Serv Adm, 2007. 30(3): p. 352-77.

226. Perry, B.L., The labeling paradox: stigma, the sick role, and social networks in mental illness. J Health Soc Behav, 2011. 52(4): p. 460-77.

227. Berger, P. and T. Luckmann, The Social Construction of Reality: A Treatise in the Sociology of Knowledge. 1966, Penguin Books.

228. Conrad, P. and K.K. Barker, The social construction of illness: key insights and policy implications. J Health Soc Behav, 2010. 51 Suppl: p. S67-79.

229. O'Dea, B. and A. Campbell, Online social networking amongst teens: friend or foe? Stud Health Technol Inform, 2011. 167: p. 133-8.

230. Li, A., D. Jiao, and T. Zhu, Detecting depression stigma on social media: A linguistic analysis. J Affect Disord, 2018. 232: p. 358-362.

231. Smith, R.S., Contested memory: Notes on Robert K. Merton's"the Thomas Theorem and the Matthew Effect". The American Sociologist, 1999. 30(2): p. 62-67.

232. Pilgrim, D. and R. Bentall, The medicalisation of misery: A critical realist analysis of the concept of depression. Journal of Mental Health, 1999. 8(3): p. 261-274.

233. van Dijk, W., et al., Medicalisation and Overdiagnosis: What Society Does to Medicine. Int J Health Policy Manag, 2016. 5(11): p. 619-622.

234. Bhugra, D., A. Ventriglio, and K.S. Bhui, What's in a name? Reclaiming mental illness. Lancet Psychiatry, 2016. 3(12): p. 1100-1101.

235. Lilienfeld, S.O. and M.T. Treadway, Clashing Diagnostic Approaches: DSM-ICD Versus RDoC. Annu Rev Clin Psychol, 2016. 12: p. 435-63.

236. Fanous, A.H., Can genomics help usher schizophrenia into the age of RDoC and DSM-6? Schizophr Bull, 2015. 41(3): p. 535-41.

237. Hayes, S.C., K.D. Strosahl, and K.G. Wilson, Acceptance and Commitment Therapy, Second Edition: The Process and Practice of Mindful Change. 2nd ed. 2012, London: The Guilford Press.

238. Insel, T., et al., Research domain criteria (RDoC): toward a new classification framework for research on mental disorders. Am J Psychiatry, 2010. 167(7): p. 748-51.

239. Berlim, M.T., M.P. Fleck, and E. Shorter, Notes on antipsychiatry. Eur Arch Psychiatry Clin Neurosci, 2003. 253(2): p. 61-7.

240. Schaefer, J.D., et al., Enduring mental health: Prevalence and prediction. J Abnorm Psychol, 2017. 126(2): p. 212-224.

241. Lewis-Fernandez, R., et al., Feasibility, acceptability and clinical utility of the Cultural Formulation Interview: mixed-methods results from the DSM-5 international field trial. Br J Psychiatry, 2017. 210(4): p. 290-297.

242. Govindarajan, R. and P. Narayanaswami, Evidence Based Medicine for Every day, Everyone and Every Therapeutic Study. Muscle Nerve, 2018.

243. Van den Broeck, K., et al., Collaborative care regarding major depressed patients: A review of guidelines and current practices. J Affect Disord, 2016. 200: p. 189-203. 
244. Gottfries, G.G., S. Noltorp, and N. Norgaard, Experience with a Swedish version of the Geriatric Depression Scale in primary care centres. Int J Geriatr Psychiatry, 1997. 12(10): p. 1029-34.

245. Jongenelis, K., et al., Diagnostic accuracy of the original 30-item and shortened versions of the Geriatric Depression Scale in nursing home patients. Int J Geriatr Psychiatry, 2005. 20(11): p. 1067-74.

246. Gordis, L., Epidemiology. 2014, Elsevier/Saunders: Philadelphia, PA p. 264-265.

247. Ostlund, U., et al., Combining qualitative and quantitative research within mixed method research designs: a methodological review. Int J Nurs Stud, 2011. 48(3): p. 369-83.

248. Kettles, A.M., J.W. Creswell, and W. Zhang, Mixed methods research in mental health nursing. J Psychiatr Ment Health Nurs, 2011. 18(6): p. 535-42.

249. Lincoln, Y.S., Y.S.L.E.G. Guba, and E.G. Guba, Naturalistic Inquiry. 1985: SAGE Publications.

250. Malterud, K., Qualitative research: standards, challenges, and guidelines. Lancet, 2001. 358(9280): p. 483-8.

251. Schillerstrom, J.E., D.R. Royall, and R.F. Palmer, Depression, disability and intermediate pathways: a review of longitudinal studies in elders. J Geriatr Psychiatry Neurol, 2008. 21(3): p. 183-97.

252. Trivedi, M.H. and T.L. Greer, Cognitive dysfunction in unipolar depression: implications for treatment. J Affect Disord, 2014. 152-154: p. 19-27.

253. Stegenga, B.T., et al., Depression, anxiety and physical function: exploring the strength of causality. J Epidemiol Community Health, 2012. 66(7): p. e25.

254. Aggernaes, B., Autism: a transdiagnostic, dimensional, construct of reasoning? Eur J Neurosci, 2018. 47(6): p. 515-533. 
ANNEX 



\section{Appendix 1. Geriatric Depression Scale -15 (GDS-15)}

Välj det bästa svaret för hur du har känt dig den senaste veckan

1. Är du i grund och botten nöjd med ditt liv? ja

NEJ

2. Har du gett upp många aktiviteter och intressen?

JA

nej

3. Tycker du att ditt liv är tomt?

4. Blir du ofta uttråkad?

5. Är du oftast på gott humör? ja

6. Är du rädd att något skall hända dig?

7. Känner du dig oftast glad och nöjd? ja

8. Känner du dig oftast hjälplös?

9. Vill du hellre stanna hemma än att gå ut och pröva nya sysselsättningar?

10.Tycker du att du har fler problem med ditt minne än de flesta andra?

11.Tycker du att det känns bra att leva?

12.Känner du dig tämligen värdelös som du är nu?

13.Känner du dig full av energi?

14.Tycker du att din situation är hopplös?

\section{Poängsättning:}

Ge 1 poäng för varje svar med stora bokstäver (versaler). 